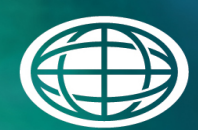

Savannah River

National Laboratory ${ }^{m}$

OPERATED BY SAVANNAH RIVER NUCLEAR SOLUTIONS

\title{
DWPF Melter Off-Gas Flammability Model for the Nitric-Glycolic Acid Flowsheet
}

\author{
A. S. Choi
}

September 2014

SRNL-STI-2014-00355 
SRNL-STI-2014-00355

Revision 0

\section{DISCLAIMER}

This work was prepared under an agreement with and funded by the U.S. Government. Neither the U.S. Government or its employees, nor any of its contractors, subcontractors or their employees, makes any express or implied:

1. warranty or assumes any legal liability for the accuracy, completeness, or for the use or results of such use of any information, product, or process disclosed; or

2. representation that such use or results of such use would not infringe privately owned rights; or

3. endorsement or recommendation of any specifically identified commercial product, process, or service.

Any views and opinions of authors expressed in this work do not necessarily state or reflect those of the United States Government, or its contractors, or subcontractors.

\section{Printed in the United States of America \\ Prepared for U.S. Department of Energy}


Keywords: DWPF, Nitric-Glycolic Acid Flowsheet, Melter Off-Gas

Flammability, CEF Phase 2

Retention: Permanent

\section{DWPF Melter Off-Gas Flammability Model for the Nitric-Glycolic Acid Flowsheet}

A. S. Choi

September 2014

Prepared for the U.S. Department of Energy under contract number DE-AC09-08SR22470.

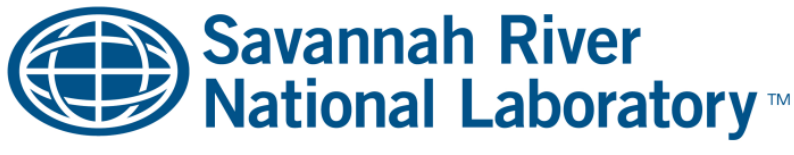

OPERATED BY SAVANNAH RIVER NUCLEAR SOLUTIONS 


\section{REVIEWS AND APPROVALS}

\section{AUTHOR:}

A. S. Choi, Process Technology Programs

Date

\section{TECHNICAL REVIEW:}

F. G. Smith, Process Modeling \& Comp Chem

Date

W. E. Daniel, Engineering Process Development

Date

\section{APPROVAL:}

D. H. McGuire, Manager

Date

Process Technology Programs

S. L. Marra, Manager

Date

Environmental \& Chemical Process Technology Research Programs

E. J. Freed, Manager

Date

DWPF/Saltstone Facility Engineering, SRR 


\section{ACKNOWLEDGEMENTS}

Expert reviews and timely programmatic guidance provided by T. L. Fellinger, E. W. Holtzscheiter, M, E. Smith of Savannah River Remediation throughout the course of this study are greatly appreciated. The author also would like to recognize the immense contributions made by F. C. Johnson (Lead), and the rest of the CEF Team members to the successful planning and execution of the CEF Phase 2 Run. The author would like to particularly single out F. C. Johnson for her dedication and efforts to coordinate post-run analysis of a too-numerous-to-count number of samples and for keeping everything in order. The author also would like to point out that the dedication by J. R. Zamecnik in setting up the comprehensive off-gas sampling system and collecting and post-run processing of a very large amount of off-gas data was central to the successful completion of this study. A timely and thorough technical review of the calculations made in this study and the report content provided by F. G. Smith and W. E. Daniel are also appreciated. Finally, support, motivation and encouragement by management (Dave McGuire) were essential to helping the author stay focused and on track for the duration of this study. 


\section{EXECUTIVE SUMMARY}

The existing DWPF melter off-gas flammability model for the nitric-formic acid flowsheet feeds has been revised to reflect the upcoming reductant change from formic to glycolic acid. The necessary data for the model revision was obtained during Phase 2 of the Cold cap Evaluation Furnace (CEF) test, which was completed on March 21, 2014 after 24 days of round-the-clock feeding and pouring, including a total downtime of $\sim 20$ hours due to equipment failures. Specifically, the CEF was run to generate steady state melter off-gas data during the first 10 days using two nitric-glycolic acid flowsheet feeds prepared from a Sludge Batch 6 (SB6) simulant at 100\% and 125\% acid stoichiometry. Each feed was run under both bubbled and non-bubbled conditions, while maintaining the CEF vapor space temperature constant for at least two hours each targeting at $700,600,500,400,350$, and $<300{ }^{\circ} \mathrm{C}$ for a total of 24 steady state runs. During the next 8 days, the CEF was run at nominal vapor space temperature of $700{ }^{\circ} \mathrm{C}$ to generate offgas surge data using the $100 \%$ acid stoichiometry feed under both bubbled and non-bubbled conditions. The remaining days were spent on producing additional steady state data using the $100 \%$ acid stoichiometry feed spiked with excess antifoam as well as re-running some of the earlier steady state runs.

The results of the Phase 2 data analysis showed that at vapor space gas temperatures $\left(T_{\text {gas }}\right)$ below $\sim 40{ }^{\circ} \mathrm{C}$ under non-bubbled conditions, each carbon in the nitric-glycolic acid flowsheet feed produced about $1 / 4$ of the $\mathrm{H}_{2}$ produced by each carbon in the nitric-formic acid flowsheet feed that was run during the Phase 1 $\mathrm{CEF}$ test in 2013. As $T_{\text {gas }}$ increased above $440{ }^{\circ} \mathrm{C}$, the difference between the $\mathrm{H}_{2}$-to-TOC ratios of the two feeds narrowed until they essentially became equal at $T_{\text {gas }}>500{ }^{\circ} \mathrm{C}$. Since the flammability assessment for the baseline off-gas surge is made at $T_{\text {gas }}<400{ }^{\circ} \mathrm{C}$, it can be concluded that on a per carbon basis the nitric-glycolic acid flowsheet feed has only $1 / 4$ of the off-gas flammability potential of the nitric-formic acid flowsheet feed, which is attributed to the fact that the nitric-glycolic acid flowsheet feed has 3.6X higher nitrate (oxidant) than the nitric-formic acid flowsheet feed. Although no direct comparison can be made for bubbled operation due to lack of the equivalent data for the nitric-formic acid flowsheet feed, the same trend of much lower flammability potential for the nitric-glycolic acid flowsheet feeds should continue under bubbled conditions. The measured concentration of $\mathrm{H}_{2}$ in the off-gas was higher under bubbled than non-bubbled conditions at all $T_{g a s}$ and data seems to suggest that it is primarily due to the increased feed rate induced by the bubbling at a fixed air purge rate.

It appears that the 3.6X higher nitrate content of the nitric-glycolic acid flowsheet feed also led to greater off-gas surging tendency than the nitric-formic acid flowsheet feed because nitrate is not only an oxidant but one of the main gas generators in the cold cap. Data showed that the nitric-glycolic acid flowsheet feed produced pressure spikes $<2$ " $\mathrm{H}_{2} \mathrm{O}$ at an order of magnitude higher frequency than the nitric-formic acid flowsheet feed did during the $2010 \mathrm{CEF}$ run. However, pressure spikes of these small magnitudes are not expected to present any significant operational difficulties in the DWPF, especially considering that the DWPF melter is equipped with a fast-acting pressure control system. It was also found that the nitricglycolic acid flowsheet feeds produced pressure spikes $>5 " \mathrm{H}_{2} \mathrm{O}$ at about the same frequency as the nitric-formic acid flowsheet feed; however, the largest pressure spike measured during Phase 2 under bubbled conditions was in excess of 13 " $\mathrm{H}_{2} \mathrm{O}$, compared to $10 " \mathrm{H}_{2} \mathrm{O}$ during the 2010 CEF run. In fact, an even larger pressure spike in excess of $20 " \mathrm{H}_{2} \mathrm{O}$ also occurred during Phase 2; however, it lasted for only 5 seconds, which is too short a duration to impact off-gas flammability or trigger a switchover to the backup off-gas system. A further analysis of the 13 " $\mathrm{H}_{2} \mathrm{O}$ pressure spike data showed that the off-gas flow at the peak of the surge was equivalent to $12 \mathrm{X}$ normal condensable and $4 \mathrm{X}$ normal non-condensable flows $(12 \mathrm{X} / 4 \mathrm{X})$. Since all the attributes of the $13 " \mathrm{H}_{2} \mathrm{O}$ pressure spike matched well those of the design basis off-gas surge used in the safety basis, the $12 \mathrm{X} / 4 \mathrm{X}$ surge will be used as the baseline surge for bubbled operation with the nitric-glycolic acid flowsheet feeds. As a comparison, the current off-gas surge basis for the nitric-formic acid flowsheet is $9 \mathrm{X} / 5 \mathrm{X}$ for bubbled operation. For non-bubbled operation, the $3 \mathrm{X} / 3 \mathrm{X}$ surge basis for the nitric-formic acid flowsheet still bounds the nitric-glycolic acid flowsheet. 
All the key components of the existing model construct are retained in the revised model. Instead, the impact of the new flowsheet chemistry is modeled by adding three new parameters. The first parameter sets the portion of nitrate in the feed to be excluded from the cold cap model input, effectively reducing its oxidizing potential. The physical justification for this supposition is that since nitrate is present at such a high concentration in the feed, it is conceivable that some fraction of it will decompose and leave the cold cap without fully imparting its oxidizing power on other feed components. The fraction of nitrate to be excluded was determined by matching the calculated concentrations of $\mathrm{H}_{2}$ and $\mathrm{CO}$ with those measured at the lowest vapor space temperatures at near $300{ }^{\circ} \mathrm{C}$ or lower as closely as possible for each steady state series. The removal fractions thus determined for the $100 \%$ and $125 \%$ acid stoichiometry feeds were $22 \%$ and $29 \%$, respectively; the higher removal fraction for the $125 \%$ acid stoichiometry feed was expected because its nitrate level was $\sim 15 \%$ higher than that of the $100 \%$ acid stoichiometry feed.

The second parameter sets the conversion of glycolic acid decomposition to $\mathrm{CO}$ and $\mathrm{H}_{2}$ as a function of vapor space temperature by matching the calculated concentration of $\mathrm{CO}$ with $125 \%$ of the measured data at each $T_{\text {gas }}$ using the existing global kinetic parameters of $\mathrm{CO}$ combustion. The fractional conversions thus determined were used to derive the first-order global kinetic parameters for the glycolic acid decomposition, which will be later coded into the existing off-gas dynamics model. The off-gas dynamics model as well as the 4-stage cold cap model constitutes the DWPF melter off-gas flammability model used in Type 1 calculations. The addition of this parameter enabled successful modeling of the observed trend of monotonically increasing $\mathrm{CO}$ with increasing melter vapor space temperature, which seems counterintuitive from the combustion kinetics standpoint but is one of the unique off-gas trends seen with the nitric-glycolic acid flowsheet feed but not with the nitric-formic acid flowsheet feed.

The third parameter sets the overall conversion of $\mathrm{H}_{2}$ combustion by lumping together all the $\mathrm{H}_{2}$ inputs not only from the cold cap reactions, including the antifoam decomposition, but from the free glycolic acid decomposition. The conversion was calculated by targeting $125 \%$ of measured $\mathrm{H}_{2}$ data at each $T_{\text {gas }}$. The resulting conversions were used to derive the new global kinetic parameters of $\mathrm{H}_{2}$ combustion, which will be later coded into the existing off-gas dynamics model. It was determined that the new global kinetic parameters increase the rate of $\mathrm{H}_{2}$ combustion at $\mathrm{T}_{\text {gas }}<370{ }^{\circ} \mathrm{C}$ significantly, which should help the model predict the Phase 1 data more closely.

The revised model was tested against the steady state data taken just prior to the 13 " $\mathrm{H}_{2} \mathrm{O}$ pressure spike as well as the "bounding data" obtained during the course of pressure spike. The calculated concentrations of $\mathrm{CO}$ and $\mathrm{H}_{2}$ for the pre-surge steady state and "bounding state" runs were found to be in good agreement with their respective measured data. Although encouraging, these results should not be interpreted as a sufficient validation of the revised model because the data used was obtained during the same melter run using the same feed that produced the data used for the model revision.

One of the major difficulties encountered during this study was achieving a reasonable carbon balance. Due to very poor carbon balance, 3 out of the 24 steady state data sets collected were discarded and 19 out of the remaining 21 data sets showed a negative carbon balance, i.e., the calculated total carbon flows in the off-gas based on the feed data were lower than those based on measured $\mathrm{CO}$ and $\mathrm{CO}_{2}$ typically by more than $20 \%$. These large negative carbon balances were consistent with the finding that the calculated total organic carbon (TOC) in the remediated feeds based on the IC results was up to $18 \%$ lower than the measured TOC data by the DWPF Analytical Laboratory even after assuming 100\% retention of the antifoam added during the SRAT processing. The measured TOC data was determined to be in agreement with the total carbon emission data during batch melting of the same feeds in argon-purged crucibles. By contrast, all three TOC estimates based on the IC, TOC analysis and crucible runs agreed well for the nitric-formic acid flowsheet feeds. This suggests that the current analytical method used to detect the glycolate is under reporting it by a significant margin. 
Transitioning from one steady state to the next and holding variables constant within preset tolerance limits at each $T_{\text {gas }}$ proved to be more difficult with the nitric-glycolic acid flowsheet feeds in Phase 2 than it was with the nitric-formic acid flowsheet feed in Phase 1. As a result, acquiring necessary steady state data to meet the research needs was more challenging in Phase 2; however, melter pressure spike data does not suggest that the nitric-glycolic acid flowsheet feeds will be more difficult to process through the DWPF melter compared to the current nitric-formic acid flowsheet feeds. On the other hand, off-gas data clearly showed that the new flowsheet feeds produce much less $\mathrm{H}_{2}$ on a per carbon basis, which will help increase the operating window for mitigating potential off-gas flammability in the DWPF melter. How much larger the new operating window will be in terms of TOC, antifoam addition, air purge, and melter vapor space temperature as a result will be determined in the follow-up Type 1 calculations, once the new model is sufficiently validated.

In summary, the following conclusions are drawn based on the results of this study:

1. In the temperature range relevant to the DWPF melter off-gas flammability safety basis, the nitric-glycolic acid flowsheet feeds produce $1 / 4$ of the $\mathrm{H}_{2}$ produced by the current nitric-formic acid flowsheet feeds on a per carbon basis.

2. A new off-gas surge basis has been defined for the nitric-glycolic acid flowsheet; it consists of $12 \mathrm{X}$ normal condensable and $4 \mathrm{X}$ normal non-condensable flows $(12 \mathrm{X} / 4 \mathrm{X})$ for bubbled operation. For non-bubbled operation, the existing off-gas surge basis of $3 \mathrm{X}$ normal condensable and $3 \mathrm{X}$ normal non-condensable flows $(3 \mathrm{X} / 3 \mathrm{X})$ for the nitric-formic acid flowsheet is still bounding.

3. The existing correlation used to estimate the true gas temperature in the DWPF melter vapor space from the measured data (TI4085D) for the combustion kinetics calculations is conservative, which confirms the earlier findings of the Phase 1 study.

4. The DWPF melter off-gas flammability model has been revised for the NGA flowsheet - its new parameters are set to match $125 \%$ of the measured $\mathrm{H}_{2}$ and $\mathrm{CO}$ concentrations during Phase 2 as a conservative measure.

5. There is a high probability that the current IC analytical method is under reporting the glycolate.

It is also recommended that:

1. The current analytical method for detecting the glycolate be improved,

2. The new parameters added to the revised DWPF melter off-gas flammability model be validated prior to performing Type 1 calculations.

3. Additional small-scale tests be run using both argon-purged and closed crucibles or any variations of them to study the impact of varying carbon and nitrate on redox and $\mathrm{H}_{2}$ generation. 


\section{TABLE OF CONTENTS}

LIST OF TABLES...... xi

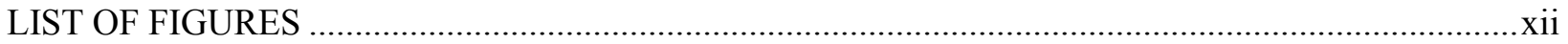

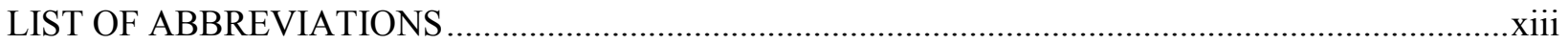

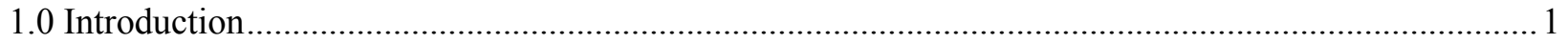

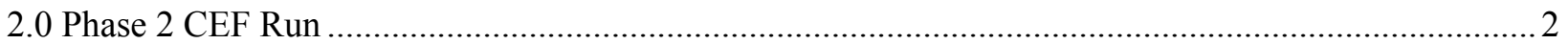

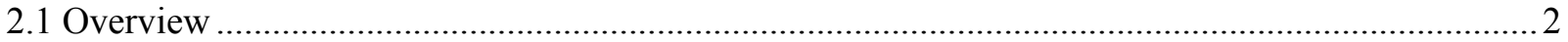

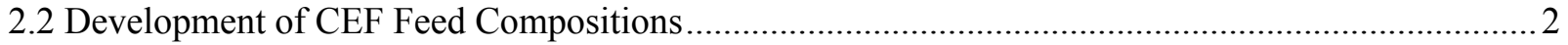

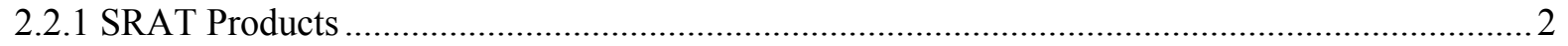

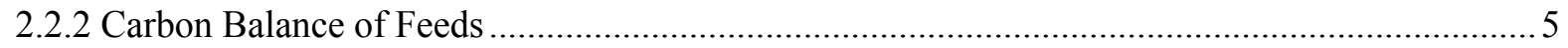

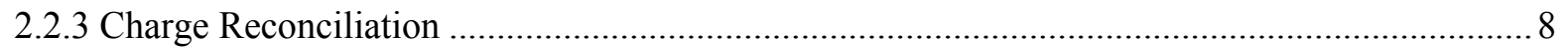

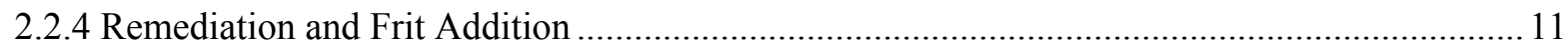

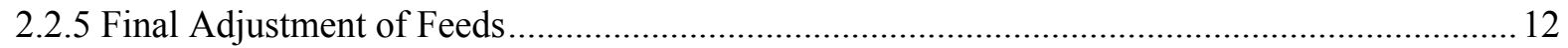

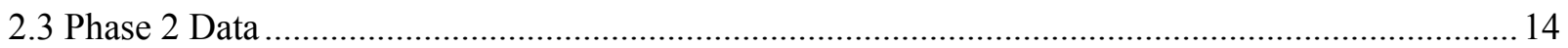

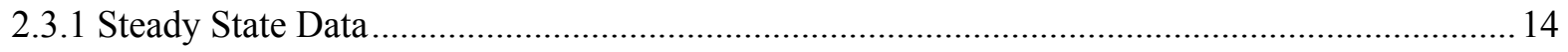

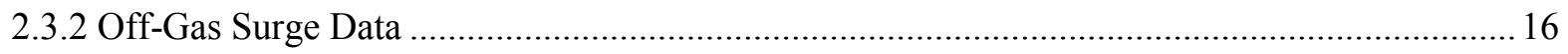

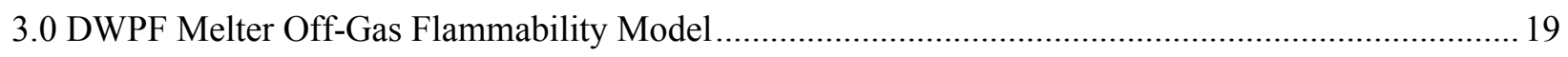

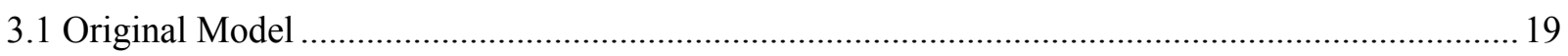

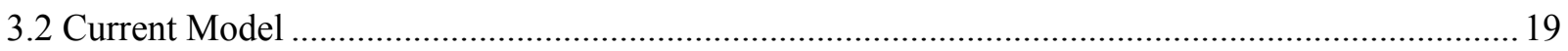

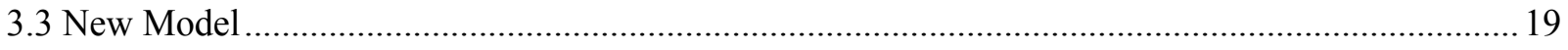

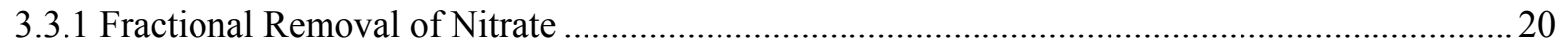

3.3.2 Fractional Conversion of Glycolic Acid Decomposition........................................................ 20

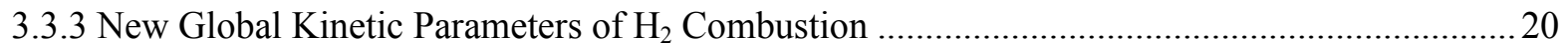

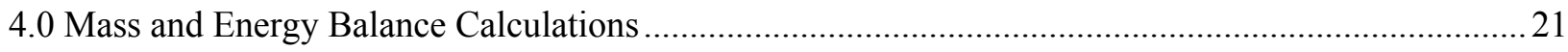

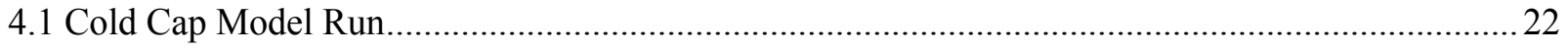

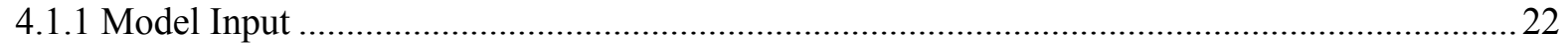

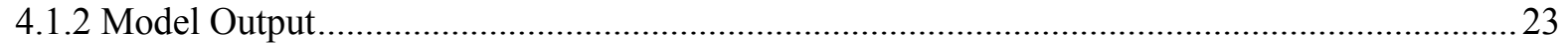

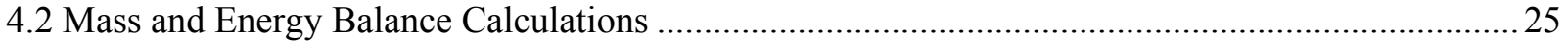

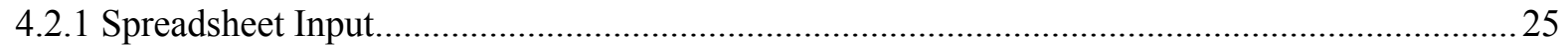

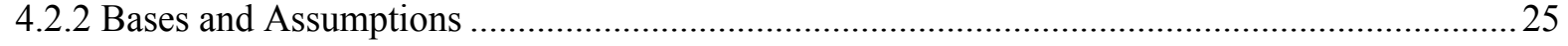

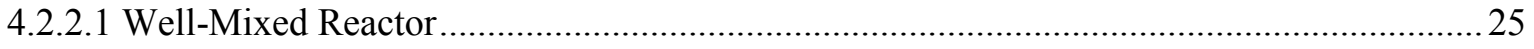

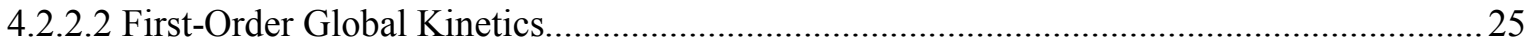

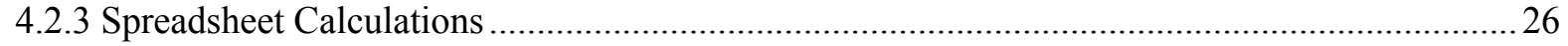




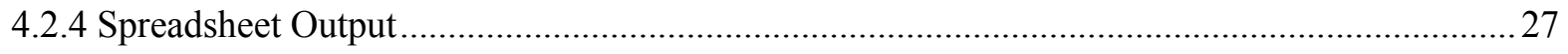

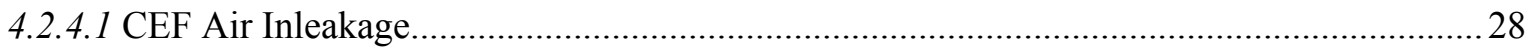

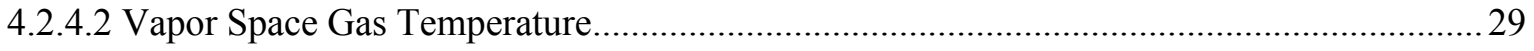

4.2.4.3 Global Kinetic Parameters of Glycolic Acid Decomposition ............................................. 31

4.2.4.4 Global Kinetic Parameters of $\mathrm{H}_{2}$ Combustion ................................................................... 33

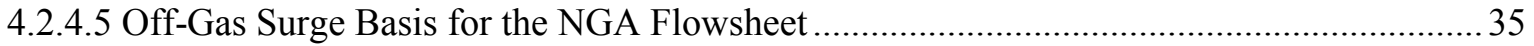

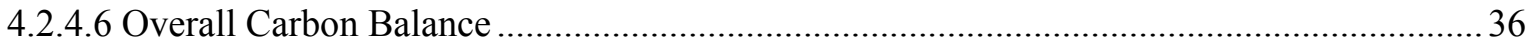

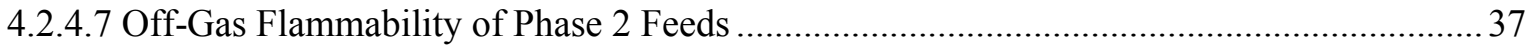

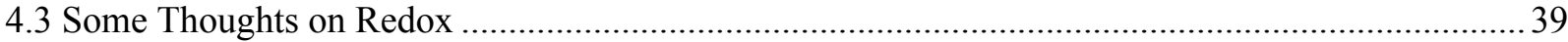

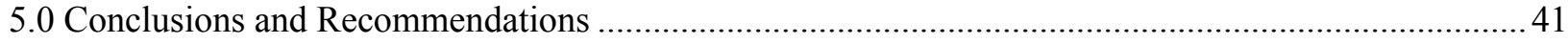

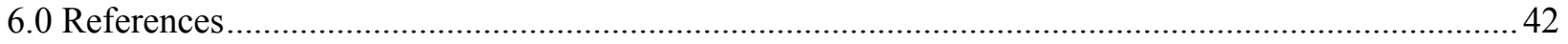

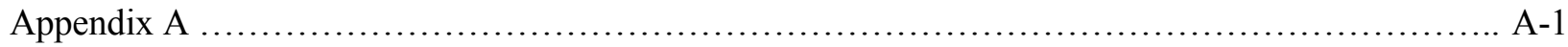

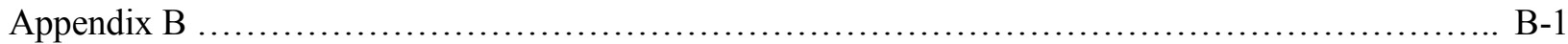




\section{LIST OF TABLES}

Table 2-1. Analytical Data for the 100\% Acid Stoichiometry SRAT Product.......................................... 3

Table 2-2. Analytical Data for the 125\% Acid Stoichiometry SRAT Product. ........................................ 4

Table 2-3. Comparison of Anion Measurements by AD and PSAL ....................................................... 5

Table 2-4. Comparison of Measured vs. Calculated TOC in Various Feeds. ............................................... 7

Table 2-5. Soluble Fractions in Charge Reconciled SRAT Products. ........................................................ 8

Table 2-6. Composition of Charge Reconciled 100\% Acid Stoichiometry SRAT Product. ..................... 10

Table 2-7. Composition of Charge Reconciled 125\% Acid Stoichiometry SRAT Product. ..................... 11

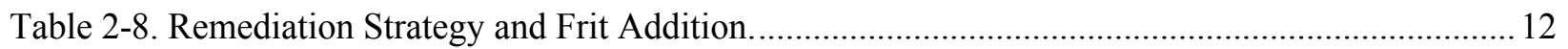

Table 2-9. Comparison of Final 100\% and 125\% Acid Stoichiometry Feeds. ...................................... 13

Table 2-10. Average CEF Operating and Off-Gas Data During Phase 2 Steady State Runs. ................... 15

Table 2-11. Number of Pressure Spikes during CEF Runs.................................................................... 17

Table 4-1. 4-Stage Cold Cap Model Input at 228 lb/hr Glass Rate (100\% Acid)...................................22

Table 4-2. 4-Stage Cold Cap Model Input at 228 lb/hr Glass Rate (125\% Acid)................................... 23

Table 4-3. 4-Stage Cold Cap Model Output at 228 lb/hr Glass Rate..................................................... 24

Table 4-4. First-Order Global Kinetic Parameters for Vapor Space Combustion. ${ }^{18}$................................ 26

Table 4-5. Output of CEF Phase 2 Off-Gas Calculations........................................................................... 27

Table 4-6. First-Order Global Kinetic Parameters of Glycolic Acid Decomposition................................. 32

Table 4-7. First-Order Global Kinetic Parameters of $\mathrm{H}_{2}$ Combustion @ $1 \mathrm{X}$ Antifoam............................ 34

Table 4-8. Steady State and Bounding $\mathrm{H}_{2}$ and $\mathrm{CO}$ during 13" $\mathrm{H}_{2} \mathrm{O}$ Pressure Spike............................... 35

Table 4-9. Comparison of Redox of Phase 1 and Phase 2 Feeds............................................................. 39 


\section{LIST OF FIGURES}

Figure 2-1. Free Acid Fraction of Glycolate vs. pH. 13

Figure 2-2. Cumulative $\mathrm{H}_{2}$ Evolution during Batch-Melting in Ar-Purged Crucible. ${ }^{14}$ 16

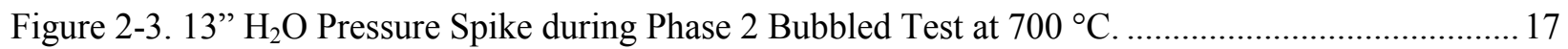

Figure 2-4. Profiles of Film Cooler $\Delta \mathrm{P}$ and $\mathrm{CO}_{2}$ during $13 " \mathrm{H}_{2} \mathrm{O}$ Pressure Spike. ................................ 18

Figure 4-1. Calculated Air Inleakage during 125\%_B_1X Run..............................................................2 28

Figure 4-2. Comparison of Air Inleakage Rates among CEF Runs.....................................................29

Figure 4-3. Measured vs. Calculated Gas Temperature during 100\%_NB_1X....................................... 30

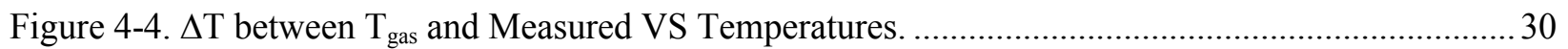

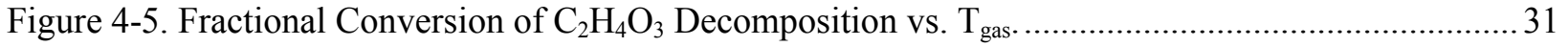

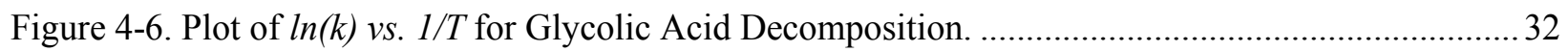

Figure 4-7. Profiles of First-Order Rate Constants of Glycolic Acid Decomposition.............................. 33

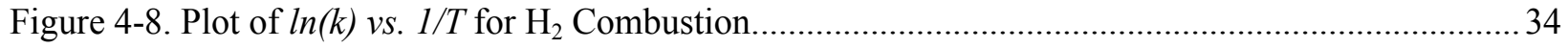

Figure 4-9. Profiles of First-Order Rate Constants of $\mathrm{H}_{2}$ Combustion................................................... 35

Figure 4-10. Measured $\mathrm{H}_{2}$ /TOC Ratios of Phase 1 vs. Phase 2 Feed. .................................................. 38

Figure 4-11. Measured CO/TOC Ratios of Phase 1 vs. Phase 2 Feed....................................................... 38

Figure 4-12. Impact of Bubbling on $\mathrm{H}_{2}$ and Feed Rate (100\% Acid)...................................................... 39 


\section{LIST OF ABBREVIATIONS}

\begin{tabular}{|c|c|}
\hline $\mathrm{AD}$ & Analytical Development \\
\hline $\mathrm{CEF}$ & Cold cap Evaluation Furnace \\
\hline $\mathrm{CPC}$ & Chemical Processing Cell \\
\hline DCS & Distributed Control System \\
\hline DWPF & Defense Waste Processing Facility \\
\hline FTIR & Fourier Transform Infrared Spectroscopy \\
\hline GC & Gas Chromatography \\
\hline IC & Ion Chromatography \\
\hline $\mathrm{ICP}$ & Invariant Condensed Phase \\
\hline ICP-MS & Inductively Coupled Plasma Mass Spectrometry \\
\hline LFL & Lower Flammability Limit \\
\hline $\mathrm{MCU}$ & Modular Caustic-side solvent extraction Unit \\
\hline MFT & Melter Feed Tank \\
\hline MS & Mass Spectrometry \\
\hline MOG & Melter Off-Gas \\
\hline NFA & Nitric-formic acid \\
\hline NGA & Nitric-glycolic acid \\
\hline OGCT & Off-Gas Condensate Tank \\
\hline PEO & polyethylene oxide \\
\hline PSAL & Process Science Analytical Laboratory \\
\hline SB & Sludge Batch \\
\hline SGM & Scale Glass Melter \\
\hline SL & Slurry \\
\hline SME & Sludge Mix Evaporator \\
\hline SN & Supernate \\
\hline SRAT & Sludge Receipt and Adjustment Tank \\
\hline SRNL & Savannah River National Laboratory \\
\hline SRR & Savannah River Remediation \\
\hline SVOA & Semi-Volatile Organics \\
\hline TOC & total organic carbon \\
\hline TSR & Technical Safety Requirements \\
\hline
\end{tabular}




\subsection{Introduction}

The Defense Waste Processing Facility (DWPF) at the Department of Energy's (DOE) Savannah River Site (SRS) is planning a flowsheet change to replace formic acid with glycolic acid as the baseline reductant for the high-level waste (HLW) melter feed. ${ }^{1}$ Nitric acid is used in conjunction with either formic or glycolic acid to neutralize the alkaline sludge from the Tank Farms. Thus, the existing flowsheet is referred to as the nitric-formic acid (NFA) flowsheet, while the new flowsheet is referred to as the nitric-glycolic acid (NGA) flowsheet. Prior to the implementation, the processability of the NGA flowsheet feeds through a melter was demonstrated during the Phase 2 Cold-cap Evaluation Furnace (CEF) test, which lasted for 24 days with round-the-clock feeding and pouring. Concurrently with the melter demonstration, the required sets of data for the development of the DWPF melter off-gas flammability technical bases for the NGA flowsheet were also collected: (1) steady state melter and off-gas data with the vapor space temperature held constant for two hours each at $700,600,500,400,350$, and $<300{ }^{\circ} \mathrm{C}$, (2) off-gas surge data for both condensable and non-condensable flows, and (3) additional steady state data using the feeds spiked with excess antifoam. ${ }^{2}$ Two NGA flowsheet feeds at $100 \%$ and $125 \%$ acid stoichiometry were used to produce Set 1, whereas only the $100 \%$ acid stoichiometry feed was used to produce Sets 2 and 3. Moreover, Sets 1 and 2 were repeated for bubbled and non-bubbled conditions, while Set 3 was produced only under non-bubbled conditions.

A detailed description of the Phase 2 CEF test is given elsewhere along with the data collected. ${ }^{3}$ The purpose of this study was to reconcile/analyze the data, develop a new off-gas surge basis, and develop a new DWPF melter off-gas flammability model for the NGA flowsheet. An earlier melter run performed in support of the down-select process showed that a significant fraction of the glycolate ion in the NGA flowsheet feed could remain as free acid and, upon entering the melter, volatilize and/or get entrained into the off-gas system. ${ }^{4}$ Samples of the off-gas condensate and filtered solids were also analyzed, and the results on the extents of glycolate and particulate entrainments are presented in the Phase 2 Run report. ${ }^{3}$

The CEF is a $1 / 11^{\text {th }}$ scale DWPF melter based on the effective melt surface area, excluding those areas occupied by various penetrations. ${ }^{5}$ It was used in 2010 to study the impact of glass bubblers on melter off-gas surging, ${ }^{6}$ and the frequency and intensity of the off-gas surges during bubbled and non-bubbled CEF operations were found to be prototypic of the DWPF melter pressure spike data collected during the 6 months before and 6 months after the bubblers went into operation. ${ }^{7}$ The CEF was also shown to be prototypic in terms of predicting the flammability potential of the DWPF melter off-gas; ${ }^{8}$ the predicted concentrations of $\mathrm{H}_{2}$ and $\mathrm{CO}$ by the existing DWPF melter off-gas flammability model correctly trended and further bounded the respective measured data in the off-gas produced with the NFA flowsheet feed during CEF Phase 1. The seemingly-excessive over prediction of the Phase $1 \mathrm{H}_{2}$ data at the vapor space gas temperature $\left(\mathrm{T}_{\text {gas }}\right)$ below $\sim 350{ }^{\circ} \mathrm{C}$ was attributed to the conservative antifoam decomposition scheme added recently to the model and, therefore, was considered a modeling issue and not a design issue. It was also shown that the thermal characteristics of the CEF vapor space are prototypic thanks to its prototypic design. ${ }^{8}$

It is ensured by the results of the earlier CEF tests that the data taken during the Phase 2 test will be also prototypic and thus suitable to be used as the basis for developing the new DWPF melter flammability technical bases for the NGA flowsheet. This report details the results of the Phase 2 data analysis, highlights some of the characteristic features of melter operation with the NGA flowsheet feeds, and documents the key bases and assumptions of the new DWPF melter off-gas flammability model. 
SRNL-STI-2014-00355

Revision 0

\subsection{Phase 2 CEF Run}

\subsection{Overview}

A total of 24 steady state data points were collected using two NGA flowsheet feeds prepared at $100 \%$ and $125 \%$ acid stoichiometry with each fed at 6 different vapor space temperatures under bubbled and non-bubbled conditions. Efforts were made to maintain steady state operation at each vapor space temperature for at least 2 hours; however, doing so proved to be more difficult than with the NFA flowsheet feed during Phase 1, as the system parameters fluctuated more and often started to drift suddenly. As a result, transitioning from one steady state to the next took longer, particularly under bubbled conditions, and it appears that all these difficulties arose largely due to the fact that the NGA flowsheet feed has a significantly higher concentration of nitrate than the NFA flowsheet feed. That is, with the nitrate being one of the main contributors to the calcine gas evolution, turbulence in the cold cap and thus departure from steady operation is more likely with increasing nitrate content. To see how large the difference in nitrate content of the two flowsheet feeds, it was estimated that each glycolate carbon in the NGA flowsheet feeds used in Phase 2 was counterbalanced by $\sim 4 \mathrm{X}$ higher nitrate than each formate carbon in the NFA flowsheet feed used in Phase 1 for the same redox target. High nitrate is the key characteristic of the NGA flowsheet feed whose impact is manifested in nearly all Phase 2 data presented later in this report.

\subsection{Development of CEF Feed Compositions}

The sludge simulant used was the same Sludge Batch 6 simulant recipe I (SB6I) used in Phase 1. Mercury and noble metals were not included in SB6I since they are not known to affect the melter off-gas flammability directly, and thus inclusion of these species was not considered a prerequisite for the melter feed simulants used in both CEF tests. ${ }^{24}$ However, their presence is known to strongly affect the oxidant (nitrate) and reductant (carbon) balances of the melter feed, which in turn affects not only the rheological properties but the cold cap chemistry in terms of redox and off-gas flammability. For this reason, a series of 4L SRAT runs were made to provide the operating instructions for the nitric and glycolic acid additions and subsequent boil-up at an off-site vendor's facility (Harrell Industries) so that the SRAT products would meet all the target properties set for the Phase 2 feed in the absence of mercury and noble metals. ${ }^{9,10}$ The reductant is made up of several carbon species, including formate, glycolate and antifoam, and typically represented by the total organic carbon (TOC) data, although each carbon species has a varying reducing power. ${ }^{11}$

\subsubsection{SRAT Products}

The SRAT products received from Harrell were analyzed at SRNL, and the results are shown in Table 2-1 and Table $2-2$ for the $100 \%$ and $125 \%$ acid stoichiometry, respectively. It was noted that although the elemental results matched the expected targets for both products, the anion results were different than expected. ${ }^{12,13}$ Specifically, the nitrate concentration of the $100 \%$ acid stoichiometry SRAT product met its target but the glycolate concentration was determined to be $22 \%$ higher, which was concluded to have caused the measured redox to be significantly higher than the target, 0.47 vs. $0.15 .^{12}$

The redox outcome was reversed for the $125 \%$ acid stoichiometry SRAT product, whose major anion (nitrate, glycolate and formate) concentrations were all within $\pm 10 \%$ of their respective targets but measured TOC was $49 \%$ higher than expected. ${ }^{13}$ However, the higher than expected TOC could not explain the fact that the measured redox of $<0.02$ was significantly lower than the target of 0.2-0.3. Subsequently, these large discrepancies between the measured and target redox values prompted a series of crucibles studies to develop a remediation strategy to restore redox to their respective targets. 
Table 2-1. Analytical Data for the $\mathbf{1 0 0 \%}$ Acid Stoichiometry SRAT Product.

\begin{tabular}{|c|c|c|c|c|}
\hline \multirow{19}{*}{ Slurry } & Elements & $\begin{array}{r}\text { wt\% calcined } \\
\text { solids }\end{array}$ & Anions & $\begin{array}{l}\mathrm{mg} / \mathrm{Kg} \\
\text { slurry }\end{array}$ \\
\hline & $\mathrm{Al}$ & 13.486 & $\mathrm{~F}$ & $<500$ \\
\hline & $\mathrm{Ba}$ & 0.133 & $\mathrm{Cl}$ & $<500$ \\
\hline & $\mathrm{Ca}$ & 1.117 & $\mathrm{NO}_{2}$ & $<500$ \\
\hline & $\mathrm{Cr}$ & 0.175 & $\mathrm{NO}_{3}$ & 70,538 \\
\hline & $\mathrm{Cu}$ & 0.125 & $\mathrm{C}_{2} \mathrm{H}_{3} \mathrm{O}_{3}$ & 44,166 \\
\hline & $\mathrm{Fe}$ & 21.305 & $\mathrm{SO}_{4}$ & 1,529 \\
\hline & $\mathrm{K}$ & 0.313 & $\mathrm{C}_{2} \mathrm{O}_{4}$ & 1,796 \\
\hline & $\mathrm{Mg}$ & 0.852 & $\mathrm{COOH}$ & 2,545 \\
\hline & $\mathrm{Mn}$ & 6.825 & $\mathrm{PO}_{4}$ & $<500$ \\
\hline & $\mathrm{Na}$ & 13.761 & Bulk Properties & \\
\hline & $\mathrm{Ni}$ & 2.951 & Total solids & $32.27 \%$ \\
\hline & $\mathrm{P}$ & $<0.100$ & Insoluble solids & $15.81 \%$ \\
\hline & $\mathrm{S}$ & 0.354 & Soluble solids & $16.46 \%$ \\
\hline & $\mathrm{Si}$ & 1.418 & Calcined solids & $17.97 \%$ \\
\hline & $\mathrm{Sn}$ & 0.060 & Density $(\mathrm{g} / \mathrm{mL})$ & \\
\hline & $\mathrm{Ti}$ & 0.051 & - slurry & 1.2514 \\
\hline & $\mathrm{Zn}$ & 0.111 & - supernate & 1.1340 \\
\hline & $\mathrm{Zr}$ & $<0.100$ & $\mathrm{pH}$ & 5.03 \\
\hline \multirow{19}{*}{ Supernate } & Cations & $\mathrm{mg} / \mathrm{L}$ & Anions & $\mathrm{mg} / \mathrm{L}$ \\
\hline & $\mathrm{Al}$ & 349.15 & $\mathrm{~F}$ & $<500$ \\
\hline & $\mathrm{Ba}$ & 1.716 & $\mathrm{Cl}$ & 565 \\
\hline & $\mathrm{Ca}$ & 2,653 & $\mathrm{NO}_{2}$ & $<500$ \\
\hline & $\mathrm{Cr}$ & 1.544 & $\mathrm{NO}_{3}$ & 92,000 \\
\hline & $\mathrm{Cu}$ & 56.125 & $\mathrm{C}_{2} \mathrm{H}_{3} \mathrm{O}_{3}$ & 60,050 \\
\hline & $\mathrm{Fe}$ & 304.75 & $\mathrm{SO}_{4}$ & 2,628 \\
\hline & $\mathrm{K}$ & 755.591 & $\mathrm{C}_{2} \mathrm{O}_{4}$ & 2,563 \\
\hline & $\mathrm{Mg}$ & $2,021.75$ & $\mathrm{COOH}$ & 2903 \\
\hline & $\mathrm{Mn}$ & 14,550 & $\mathrm{PO}_{4}$ & $<500$ \\
\hline & $\mathrm{Na}$ & 31,850 & & \\
\hline & $\mathrm{Ni}$ & 2,720 & Misc. Data & \\
\hline & $\mathrm{P}$ & $<10.0$ & Redox & $\mathrm{Fe}^{2+} / \Sigma \mathrm{Fe}$ \\
\hline & $\mathrm{S}$ & 817.75 & - Measured & 0.47 \\
\hline & $\mathrm{Si}$ & 706.5 & - Target & 0.15 \\
\hline & $\mathrm{Sn}$ & 9.515 & TOC (mg/kg) & \\
\hline & $\mathrm{Ti}$ & 0.323 & $-\mathrm{AD}$ & 12,546 \\
\hline & $\mathrm{Zn}$ & 55.663 & - DWPF Lab & 20,790 \\
\hline & $\mathrm{Zr}$ & $<0.100$ & & \\
\hline
\end{tabular}


SRNL-STI-2014-00355

Revision 0

Table 2-2. Analytical Data for the 125\% Acid Stoichiometry SRAT Product.

\begin{tabular}{|c|c|c|c|c|}
\hline \multirow{19}{*}{ Slurry } & Elements & $\begin{array}{r}\text { wt\% calcined } \\
\text { solids }\end{array}$ & Anions & $\begin{array}{r}\mathrm{mg} / \mathrm{Kg} \\
\text { slurry }\end{array}$ \\
\hline & $\mathrm{Al}$ & 14.357 & $\mathrm{~F}$ & $<500$ \\
\hline & $\mathrm{Ba}$ & 0.126 & $\mathrm{Cl}$ & $<500$ \\
\hline & $\mathrm{Ca}$ & 1.229 & $\mathrm{NO}_{2}$ & $<500$ \\
\hline & $\mathrm{Cr}$ & 0.175 & $\mathrm{NO}_{3}$ & 91,303 \\
\hline & $\mathrm{Cu}$ & 0.117 & $\mathrm{C}_{2} \mathrm{H}_{3} \mathrm{O}_{3}$ & 47,153 \\
\hline & $\mathrm{Fe}$ & 21.560 & $\mathrm{SO}_{4}$ & 1,651 \\
\hline & $\mathrm{K}$ & 0.293 & $\mathrm{C}_{2} \mathrm{O}_{4}$ & 1,723 \\
\hline & $\mathrm{Mg}$ & 0.837 & $\mathrm{COOH}$ & 1,073 \\
\hline & $\mathrm{Mn}$ & 6.795 & $\mathrm{PO}_{4}$ & $<500$ \\
\hline & $\mathrm{Na}$ & 13.120 & \multicolumn{2}{|l|}{ Bulk Properties } \\
\hline & $\mathrm{Ni}$ & 2.897 & Total solids & $32.77 \%$ \\
\hline & $\mathrm{P}$ & $<0.100$ & Insoluble solids & $15.66 \%$ \\
\hline & $\mathrm{S}$ & 0.309 & Soluble solids & $17.12 \%$ \\
\hline & $\mathrm{Si}$ & 1.523 & Calcined solids & $17.72 \%$ \\
\hline & Sn & $<0.100$ & Density $(\mathrm{g} / \mathrm{mL})$ & \\
\hline & $\mathrm{Ti}$ & 0.050 & - slurry & 1.2553 \\
\hline & $\mathrm{Zn}$ & 0.110 & - supernate & 1.1340 \\
\hline & $\mathrm{Zr}$ & 0.142 & $\mathrm{pH}$ & 3.21 \\
\hline \multirow{19}{*}{ Supernate } & Cations & $\mathrm{mg} / \mathrm{L}$ & Anions & $\mathrm{mg} / \mathrm{L}$ \\
\hline & $\mathrm{Al}$ & 1,100 & $\mathrm{~F}$ & $<500$ \\
\hline & $\mathrm{Ba}$ & 3.461 & $\mathrm{Cl}$ & 567 \\
\hline & $\mathrm{Ca}$ & 3,135 & $\mathrm{NO}_{2}$ & $<500$ \\
\hline & $\mathrm{Cr}$ & 4.350 & $\mathrm{NO}_{3}$ & 118,000 \\
\hline & $\mathrm{Cu}$ & 182.535 & $\mathrm{C}_{2} \mathrm{H}_{3} \mathrm{O}_{3}$ & 59,650 \\
\hline & $\mathrm{Fe}$ & 2,700 & $\mathrm{SO}_{4}$ & 3,120 \\
\hline & $\mathrm{K}$ & 1,075 & $\mathrm{C}_{2} \mathrm{O}_{4}$ & 3,200 \\
\hline & $\mathrm{Mg}$ & $2,354.865$ & $\mathrm{COOH}$ & $<500$ \\
\hline & $\mathrm{Mn}$ & 13,600 & $\mathrm{PO}_{4}$ & $<500$ \\
\hline & $\mathrm{Na}$ & 33,900 & & \\
\hline & $\mathrm{Ni}$ & 5,345 & Misc. Data & \\
\hline & $\mathrm{P}$ & 18.565 & Redox & $\mathrm{Fe}^{2+} / \Sigma \mathrm{Fe}$ \\
\hline & $\mathrm{S}$ & 766.228 & - Measured & $<0.02$ \\
\hline & $\mathrm{Si}$ & 297.855 & - Target & $0.2-0.3$ \\
\hline & $\mathrm{Sn}$ & 6.233 & TOC (mg/kg) & \\
\hline & $\mathrm{Ti}$ & 3.530 & $-\mathrm{AD}$ & 23,300 \\
\hline & $\mathrm{Zn}$ & 144 & - DWPF Lab & 21,062 \\
\hline & $\mathrm{Zr}$ & 0.100 & & \\
\hline
\end{tabular}




\subsubsection{Carbon Balance of Feeds}

The redox of a given feed is determined strictly by the balance between the oxidant (nitrate) and reductant (glycolate, oxalate, formate, and antifoam) concentrations. Since both SRAT products missed their respective redox targets widely despite having followed the recipes provided by SRNL, it was decided to reexamine all the available anion data to determine the potential cause(s) for such large discrepancies in redox. Accurately knowing the concentrations of the oxidants and reductants present in the feed is also critically important to the success of this study whose scope is to interpret the Phase 2 data, extract the kinetic parameters of key reactions involving carbon species, and develop a new DWPF off-gas flammability model using those kinetic parameters.

Both elemental and anion data reported in Table 2-1 and Table 2-2 was measured at the Process Science Analytical Laboratory (PSAL) of SRNL. Samples were re-analyzed for anions only by the Analytical Development (AD) of SRNL, and the results are compared in Table 2-3. For the $100 \%$ acid stoichiometry SRAT product, the agreement between the two lab results is quite good for the two main anions, nitrate and glycolate. Discrepancies in oxalate, formate and sulfate are not as important due to their low concentrations and thus low impact on both redox and off-gas flammability. For the $125 \%$ acid stoichiometry SRAT product, the measured nitrate and glycolate by $\mathrm{AD}$ are larger than those by PSAL but the differences are still within $10 \%$. The next 3 samples represent the actual feeds used in Phase 2, after each SRAT product was remediated and blended with Frit 418 . It is clearly seen that the measured nitrate values by PSAL and AD remain well within $\pm 10 \%$ of each other; for the feed spiked with $2 \mathrm{X}$ antifoam, the difference is larger at $11 \%$. However, the measured glycolate data by AD are up to 30\% higher than the PSAL data.

Table 2-3. Comparison of Anion Measurements by AD and PSAL.

\begin{tabular}{|c|c|c|c|c|c|}
\hline & $\mathrm{NO}_{3}$ & $\mathrm{C}_{2} \mathrm{H}_{3} \mathrm{O}_{3}$ & $\mathrm{SO}_{4}$ & $\mathrm{C}_{2} \mathrm{O}_{4}$ & COOH \\
\hline & $\mathrm{mg} / \mathrm{Kg}$ & $\mathrm{mg} / \mathrm{Kg}$ & $\mathrm{mg} / \mathrm{Kg}$ & $\mathrm{mg} / \mathrm{Kg}$ & $\mathrm{mg} / \mathrm{Kg}$ \\
\hline \multicolumn{6}{|c|}{ 100\% Acid, SRAT Product } \\
\hline AD Average & 70,538 & 44,166 & 1,529 & 1,796 & 2,545 \\
\hline PSAL average & 66,950 & 44,525 & 1,863 & 2,005 & 3,135 \\
\hline$\Delta$ & $5.4 \%$ & $-0.8 \%$ & $-17.9 \%$ & $-10.4 \%$ & $-18.8 \%$ \\
\hline \multicolumn{6}{|c|}{ 125\% Acid, SRAT Product } \\
\hline AD Average & 91,303 & 47,153 & 1,651 & 1,723 & 1,073 \\
\hline PSAL average & 84,850 & 43,500 & 2,695 & 2,155 & $<500$ \\
\hline$\Delta$ & $7.6 \%$ & $8.4 \%$ & $-38.7 \%$ & $-20.0 \%$ & - \\
\hline \multicolumn{6}{|c|}{$125 \%$ Acid, $45 \%$, 1X Antifoam } \\
\hline AD Average & 67,341 & 43,250 & 1,282 & 1,218 & 764 \\
\hline PSAL average & 66,550 & 35,650 & 1,458 & 1,288 & 1,965 \\
\hline$\Delta$ & $1.2 \%$ & $21.3 \%$ & $-12.0 \%$ & $-5.4 \%$ & $-61.1 \%$ \\
\hline \multicolumn{6}{|c|}{$100 \%$ Acid, 45\%, 1X Antifoam } \\
\hline AD Average & 58,804 & 34,665 & 1,292 & 1,130 & 1,721 \\
\hline PSAL average & 61,450 & 26,600 & 1,405 & 928 & 2,413 \\
\hline$\Delta$ & $-4.3 \%$ & $30.3 \%$ & $-8.0 \%$ & $21.7 \%$ & $-28.7 \%$ \\
\hline \multicolumn{6}{|c|}{$100 \%$ Acid, $45 \%, 2 X$ Antifoam } \\
\hline AD Average & 61,760 & 36,239 & 1,313 & 1,152 & 1,787 \\
\hline PSAL average & 55,233 & 31,033 & 854 & 944 & 1,838 \\
\hline$\Delta$ & $11.8 \%$ & $16.8 \%$ & $53.8 \%$ & $22.0 \%$ & $-2.8 \%$ \\
\hline
\end{tabular}


The TOC values of 7 different melter feeds were calculated from measured anion data by AD and the results are compared in Table 2-4 against those measured by the DWPF Analytical Laboratory $\left(\mathrm{TOC}_{\mathrm{DWPF}}\right)$. The given anion data may be somewhat different from the reported analytical results because they represent charge reconciled feeds. The given antifoam values were calculated by assuming that $100 \%$ of antifoam carbon added during the SRAT and/or SME processing remained in the feed. Another TOC measurement $\left(\mathrm{TOC}_{\text {cruc }}\right)$ was also made indirectly based on measured total carbon emission during batch melting of a slurry feed in an argon-purged crucible. Specifically, they were estimated by dividing the total mass of carbon emitted in the off-gas in $\mathrm{mg}$ by the initial batch weight of $0.01 \mathrm{~kg} .^{14}$

CEF1_Baseline is the NFA flowsheet feed used in Phase 1 and its calculated TOC $\left(\mathrm{TOC}_{\text {calc }}\right)$ is shown to be only $3 \%$ lower than the $\mathrm{TOC}_{\mathrm{DWPF}}$, while the $\mathrm{TOC}_{\text {cruc }}$ was lower by $11 \%$. The SB8-D3 series were also based on the NFA flowsheet. SB8-D3_Baseline was produced at $120 \%$ acid stoichiometry and contained less than $30 \%$ of the antifoam added to the baseline CEF Phase 1 (CEF1) or Phase 2 (CEF2) feed. ${ }^{15}$ Its calculated TOC from the anion data was practically identical to the $\mathrm{TOC}_{\mathrm{DWPF}}$, while the $\mathrm{TOC}_{\text {cruc }}$ was $8 \%$ higher. Considering that all three $\mathrm{TOC}$ values are in reasonable agreement for the two baseline NFA flowsheet feeds, it may be concluded that: (1) the $\mathrm{TOC}_{\mathrm{DWPF}}$ tracks the anion carbon data well, which is consistent with the trend seen earlier, ${ }^{16}$ and (2) no significant degradation and subsequent loss of antifoam carbon occurred during the preparation of these feeds, and (3) the TOC measurement based on the total carbon emission during batch melting in a crucible $\left(\mathrm{TOC}_{\text {cruc }}\right)$ appears to be a viable option.

When SB8-D3_Baseline was spiked with 1,600 ppm of fresh antifoam carbon, both the calculated TOC and $\mathrm{TOC}_{\text {cruc }}$ were still close to the $\mathrm{TOC}_{\mathrm{DWPF}}$, differing only by $+5 \%$. Despite the excellent agreement with an independent measurement, the carbon balance showed that $\mathrm{TOC}_{\text {cruc }}$ estimated from the total carbon emitted from this particular batch was $27 \%$ larger than the calculated total carbon based on the analytical data of the batch. ${ }^{14}$ In fact, the total carbon emissions measured during the eight batch melting tests using the argon-purged crucibles were consistently higher than those estimated from the analytical data by $15 \%-40 \%$.

When the same feed was boiled before analysis or heat-up in a crucible (SB8-D3_1600ppm-AC

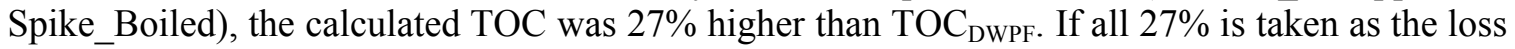
due to antifoam degradation during boil-up, it is equivalent to $\sim 90 \%$ loss of antifoam, which is significantly higher than the $20 \%$ loss estimated earlier based on data from 15 SME batches. ${ }^{16}$ And the $\mathrm{TOC}_{\text {cruc }}$ was even higher than $\mathrm{TOC}_{\mathrm{DWPF}}$ by $35 \%$, which suggests that the $\mathrm{TOC}_{\mathrm{DWPF}}$ may be at fault.

When SB8-D3_Baseline was spiked with 1,600 ppm of PEG-equivalent carbon and boiled, the calculated TOC was $6 \%$ higher than $\mathrm{TOC}_{\mathrm{DWPF}}$. If all $6 \%$ is taken as the loss due to degradation, it is equivalent to a $29 \%$ loss of PEG carbon during boil-up, which is more in line with the earlier estimate. ${ }^{16}$ On the other hand, the $\mathrm{TOC}_{\text {cruc }}$ was $26 \%$ higher than $\mathrm{TOC}_{\text {calc }}$, which is clearly outside the normal bounds of measurement errors so is in principle not feasible because the calculated TOC assumes no loss of carbon during boil-up and thus represents the theoretical maximum TOC. In addition, a quick scan of the listed $\mathrm{TOC}_{\text {cruc }}$ values for the SB8-D3 series feeds suggests that this particular data is likely at fault. 
Table 2-4. Comparison of Measured vs. Calculated TOC in Various Feeds.

\begin{tabular}{|c|c|c|c|c|c|c|c|c|c|}
\hline Sample & $\begin{array}{l}\mathrm{COOH}^{1} \\
(\mathrm{mg} / \mathrm{kg})\end{array}$ & $\begin{array}{l}\mathrm{C}_{2} \mathrm{H}_{3} \mathrm{O}_{3}{ }^{1} \\
(\mathrm{mg} / \mathrm{kg})\end{array}$ & $\begin{array}{c}\mathrm{C}_{2} \mathrm{O}_{4} \\
(\mathrm{mg} / \mathrm{kg})\end{array}$ & $\begin{array}{c}\text { Antifoam } \\
(\mathrm{mg} / \mathrm{kg})\end{array}$ & $\begin{array}{l}\mathrm{TOC}_{\text {calc }}^{2} \\
(\mathrm{mg} / \mathrm{kg})\end{array}$ & $\begin{array}{c}\mathrm{TOC}_{\mathrm{DWPF}} \\
(\mathrm{mg} / \mathrm{kg})\end{array}$ & $\begin{array}{c}\Delta \mathrm{TOC} \\
\text { (calc - } \\
\text { DWPF) }\end{array}$ & $\begin{array}{l}\mathrm{TOC}_{\text {cruc }}{ }^{3} \\
(\mathrm{mg} / \mathrm{Kg})\end{array}$ & $\begin{array}{c}\Delta \mathrm{TOC} \\
\text { (crucible } \\
\text { - DWPF) }\end{array}$ \\
\hline CEF1_Baseline & 46,098 & 0 & 12 & 3,125 & 13,873 & 14,352 & $-3 \%$ & 12,789 & $-11 \%$ \\
\hline SB8-D3_Baseline & 54,393 & 0 & 2,624 & 875 & 15,668 & 15,883 & $-1 \%$ & 17,209 & $8 \%$ \\
\hline SB8-D3_1600ppm-AC Spike_Fresh ${ }^{4}$ & 54,393 & 0 & 2,624 & 4,062 & 17,268 & 16,427 & $5 \%$ & 17,311 & $5 \%$ \\
\hline SB8-D3_1600ppm-PEG C Spike_Boiled & 54,393 & 0 & 2,624 & 4,062 & 17,268 & 16,352 & $6 \%$ & 20,610 & $26 \%$ \\
\hline CEF2_100\% Acid_Baseline & 1,751 & 34,494 & 1,236 & 2,936 & 13,322 & 16,199 & $-17 \%$ & 16,178 & $0 \%$ \\
\hline CEF2_100\% Acid_1000ppm AC Spike & 1,751 & 34,494 & 1,236 & 4,926 & 14,322 & - & - & 15,623 & - \\
\hline
\end{tabular}

1 Best possible match of AD results after charge reconciliation.

2 Assumed $100 \%$ retention of antifoam carbon added.

${ }^{3}$ Calculated as the ratio of total carbon emitted during each run to initial slurry batch weight.

4 AC stands for antifoam carbon, which makes up $50.27 \mathrm{wt} \%$ of antifoam. 
Finally, the calculated TOC for the baseline CEF Phase 2 feed is shown to be $18 \%$ lower than the $\mathrm{TOC}_{\mathrm{DWPF}}$, while the $\mathrm{TOC}_{\text {cruc }}$ was essentially identical to the $\mathrm{TOC}_{\mathrm{DWPF}}$. This result is significant because it means that the underestimation of TOC based on the anion carbon data for the NGA flowsheet feed is confirmed by two independent TOC measurements. In fact, as shown in the last column of Table 2-4, the agreement between the two TOC measurements is either excellent or reasonably good except for those spiked with excess carbons, which may be related to the large carbon imbalance in the crucible data. The potential cause for the underestimation of TOC is that the analytical method used did not detect all the glycolate ions due to their tendency to form complexes with normally insoluble metals and rendering them soluble, as shown by the results of charge reconciliation next. Another evidence of not detecting all the glycolate analytically comes from the fact that the total carbon emitted during the crucible run was $\sim 40 \%$ more than the total carbon in the CEF2_100\%_Acid_Baseline feed estimated from the anion data. ${ }^{14}$

\subsubsection{Charge Reconciliation}

The charge imbalances present in the $100 \%$ and $125 \%$ acid stoichiometry SRAT product data in Table 2-1 and Table 2-2, respectively, with the anion data replaced with the respective AD data shown in Table 2-3, were reconciled under the constraints of measured bulk properties, including $\mathrm{pH}$, in the following steps:

1. Charge balance of supernate (SN) data: The given Na data was adjusted up by $10.7 \%$ and $11.4 \%$ for the $100 \%$ and $125 \%$ acid stoichiometry SRAT products, respectively. On a slurry (SL) basis, these changes were equivalent to 5.9 and $18.9 \%$ increase above the elemental (ICP-MS) Na data for the $100 \%$ and $125 \%$ acid stoichiometry, respectively. As explained later in the report, the reason for replacing the PSAL anion data with the AD data was to reduce the shortfall in TOC compared to the measured value by DWPF.

2. Calculation of soluble fractions of metals: The elemental data given in $\mathrm{mg} / \mathrm{L} \mathrm{SN}$ was converted to per L SL basis and compared to the elemental data of the slurry. The results are compared in Table 2-5 to those calculated for the NFA flowsheet feed used in Phase 1. It is clearly seen that the solubility of these normally insoluble metals increases from the NFA to NGA flowsheet and with increasing acid stoichiometry, which may be explained in terms of the metal-glycolate complex formation.

Table 2-5. Soluble Fractions in Charge Reconciled SRAT Products.

\begin{tabular}{|c|r|r|r|}
\hline Elements & Phase 1 & $100 \%$ acid & $125 \%$ acid \\
\hline $\mathrm{Fe}$ & $0.0 \%$ & $0.6 \%$ & $5.2 \%$ \\
\hline $\mathrm{Al}$ & $0.1 \%$ & $1.1 \%$ & $3.2 \%$ \\
\hline $\mathrm{Mn}$ & $58.7 \%$ & $88.1 \%$ & $82.7 \%$ \\
\hline $\mathrm{Ca}$ & $98.8 \%$ & $98.1 \%$ & $100.0 \%$ \\
\hline $\mathrm{Mg}$ & $100.0 \%$ & $98.0 \%$ & $100.0 \%$ \\
\hline $\mathrm{Ni}$ & $24.4 \%$ & $38.1 \%$ & $76.2 \%$ \\
\hline $\mathrm{Cr}$ & $0.2 \%$ & $0.4 \%$ & $1.0 \%$ \\
\hline $\mathrm{Cu}$ & $21.4 \%$ & $18.6 \%$ & $64.4 \%$ \\
\hline $\mathrm{Ti}$ & $0.0 \%$ & $0.3 \%$ & $2.9 \%$ \\
\hline $\mathrm{Zn}$ & $9.4 \%$ & $20.8 \%$ & $54.1 \%$ \\
\hline $\mathrm{S}$ & $88.8 \%$ & $95.5 \%$ & $100.0 \%$ \\
\hline $\mathrm{I}$ & & &
\end{tabular}

At $120 \%$ acid stoichiometry 
3. Soluble metal-anion pairing: Most soluble metals in Table 2-5 were paired with $\mathrm{NO}_{3}$, $\mathrm{C}_{2} \mathrm{H}_{3} \mathrm{O}_{3}$ and $\mathrm{COOH}$ at their reported molar anion ratios.

4. Equilibrium dissociation of medium acids: The free acid (undissociated) fractions of the glycolate and formate IC data at the given $\mathrm{pH}$ were calculated for each acid- $\mathrm{H}_{2} \mathrm{O}$ binary solution using their respective pKa values of 3.83 and 3.75 at $25^{\circ} \mathrm{C}$.

5. Na partitioning: The total $\mathrm{Na}$ estimated in Step 1 was distributed among $\mathrm{C}_{2} \mathrm{O}_{4}, \mathrm{SO}_{4}, \mathrm{PO}_{4}$, $\mathrm{Cl}$, and the remaining $\mathrm{NO}_{3}, \mathrm{COOH}$ and $\mathrm{C}_{2} \mathrm{H}_{3} \mathrm{O}_{3}$. The amount of surplus anions (or $\mathrm{Na}$ ) was determined.

6. Adjustment of equilibrium dissociation: The free acid fractions calculated in Step 4 were adjusted until there were no more surplus anions in Step 5.

The compositions of the charge-reconciled $100 \%$ and $125 \%$ acid stoichiometry SRAT Products are given in Table 2-6 and Table 2-7, respectively, in a neutral species form. The calculated total insoluble and soluble solids are shown to be both within 5\% of the measured data for the $100 \%$ acid stoichiometry, while they are off by $-0.1 \%$ and $8.5 \%$, respectively, for the $125 \%$ acid stoichiometry. The concentrations of free glycolic and formic acids shown in Table 2-6 represent $9.6 \%$ and $8.6 \%$ of their respective IC data at the measured $\mathrm{pH}$ of 5.03 . When the $\mathrm{pH}$ was lowered to 3.21 for the $125 \%$ acid stoichiometry SRAT product, the calculated free acid fractions were increased to $30.8 \%$ and $20.0 \%$ of the measured glycolate and formate IC data, respectively. It is noted that both formic and glycolic acids along with $\mathrm{H}_{2} \mathrm{O}$ are listed as volatiles, although a major portion of glycolic acid may decompose at a low temperature of $\sim 112{ }^{\circ} \mathrm{C}$ rather than volatilize due to its low vapor pressure.

Since the presence of antifoam molecules cannot be detected directly by the analytical methods used, its concentration was set based on its addition recipe, $15.5 \mathrm{~kg}$ per 5,000 kg of SB6I simulant or $0.108 \mathrm{~kg} / \mathrm{kg} \mathrm{Fe},{ }^{9,10}$ and assuming $100 \%$ retention during the SRAT processing at Harrell, which included $\sim 8$ hours of boil-up. Furthermore, the oxalate was added as $\mathrm{Na}_{2} \mathrm{C}_{2} \mathrm{O}_{4}$ at a rate of 0.023 $\mathrm{kg} / \mathrm{kg} \mathrm{Fe}$; however, the measured $\mathrm{C}_{2} \mathrm{O}_{4}$ by IC was $2 \mathrm{X}$ the amount added per recipe. The oxalate concentrations shown in Table 2-6 and Table 2-7 are based on the IC data. The phosphate was added as $\mathrm{Na}_{3} \mathrm{PO}_{4} \cdot 12 \mathrm{H}_{2} \mathrm{O}$ at a rate of $0.021 \mathrm{~g} / \mathrm{g} \mathrm{Fe}$, and its IC data was below detection, i.e., $<500$ $\mathrm{mg} / \mathrm{kg}$ in both SRAT products. Thus, its concentration was derived from the ICP elemental data for $\mathrm{P}$, assuming it to be $100 \%$ soluble, and the resulting phosphate concentrations were 573 and $554 \mathrm{mg} / \mathrm{kg}$ for the $100 \%$ and $125 \%$ acid stoichiometry SRAT products, respectively, both slightly above the detection limit. 
Table 2-6. Composition of Charge Reconciled 100\% Acid Stoichiometry SRAT Product.

\begin{tabular}{|c|c|c|c|c|c|}
\hline $\begin{array}{l}\text { Insoluble } \\
\text { Solids: }\end{array}$ & $\begin{array}{r}\mathrm{g} / \mathrm{L} \\
\text { slurry }\end{array}$ & Soluble Solids: & $\begin{array}{r}\mathrm{g} / \mathrm{L} \\
\text { slurry }\end{array}$ & Soluble Solids: & $\begin{array}{r}\mathrm{g} / \mathrm{L} \\
\text { slurry }\end{array}$ \\
\hline $\mathrm{Fe}(\mathrm{OH}) 3$ & 94.4017 & $\mathrm{Ca}(\mathrm{COOH}) 2$ & 0.1772 & $\mathrm{Ni}(\mathrm{COOH}) 2$ & 0.1418 \\
\hline $\mathrm{Al}(\mathrm{OH}) 3$ & 89.8425 & $\mathrm{Ca}(\mathrm{C} 2 \mathrm{H} 3 \mathrm{O} 3) 2$ & 4.1226 & $\mathrm{Ni}(\mathrm{C} 2 \mathrm{H} 3 \mathrm{O} 3) 2$ & 3.1693 \\
\hline $\mathrm{MnO} 2$ & 3.0043 & $\mathrm{Ca}(\mathrm{NO} 3) 2$ & 6.6678 & $\mathrm{Ni}(\mathrm{NO} 3) 2$ & 5.1985 \\
\hline $\mathrm{Ca}(\mathrm{OH}) 2$ & 0.0899 & $\mathrm{Fe}(\mathrm{COOH}) 3$ & 0.0214 & $\mathrm{Zn}(\mathrm{COOH}) 2$ & 0.0027 \\
\hline $\mathrm{Mg}(\mathrm{OH}) 2$ & 0.0962 & $\mathrm{Fe}(\mathrm{C} 2 \mathrm{H} 3 \mathrm{O} 3) 3$ & 0.5022 & $\mathrm{Zn}(\mathrm{C} 2 \mathrm{H} 3 \mathrm{O} 3) 2$ & 0.0601 \\
\hline $\mathrm{Ni}(\mathrm{OH}) 2$ & 6.7236 & $\mathrm{Fe}(\mathrm{NO} 3) 3$ & 0.8103 & $\mathrm{Zn}(\mathrm{NO} 3) 2$ & 0.0990 \\
\hline $\mathrm{Cr}(\mathrm{OH}) 3$ & 0.8063 & $\mathrm{Al}(\mathrm{COOH}) 3$ & 0.0431 & $\mathrm{H} 4 \mathrm{SiO} 4$ & 2.3262 \\
\hline $\mathrm{Cu}(\mathrm{OH}) 2$ & 0.3623 & $\mathrm{Al}(\mathrm{C} 2 \mathrm{H} 3 \mathrm{O} 3) 3$ & 1.0686 & Total Soluble & 215.7206 \\
\hline $\mathrm{K} 2 \mathrm{O}$ & 0.0038 & $\mathrm{Al}(\mathrm{NO} 3) 3$ & 1.6923 & Measured SS & 206.0276 \\
\hline $\mathrm{TiO} 2$ & 0.1975 & $\mathrm{Cu}(\mathrm{COOH}) 2$ & 0.0028 & $\Delta(\%)$ & 4.7047 \\
\hline $\mathrm{SiO} 2$ & 5.6106 & $\mathrm{Cu}(\mathrm{C} 2 \mathrm{H} 3 \mathrm{O} 3) 2$ & 0.0618 & & \\
\hline $\mathrm{Sn}(\mathrm{OH}) 2$ & 0.0892 & $\mathrm{Cu}(\mathrm{NO} 3) 2$ & 0.1017 & Volatiles & \\
\hline $\mathrm{Zn}(\mathrm{OH}) 2$ & 0.3099 & $\mathrm{KCOOH}$ & 0.0335 & $\mathrm{HCOOH}$ & 0.2814 \\
\hline BaSO4 & 0.5278 & $\mathrm{KC} 2 \mathrm{H} 3 \mathrm{O} 3$ & 0.7225 & $\mathrm{C} 2 \mathrm{H} 4 \mathrm{O} 3$ & 6.0753 \\
\hline $\mathrm{ZrO} 2$ & 0.0000 & KNO3 & 1.1996 & $\mathrm{H} 2 \mathrm{O}$ & 821.8996 \\
\hline CaSO4 & 0.0000 & $\mathrm{Mg}(\mathrm{COOH}) 2$ & 0.1957 & & \\
\hline $\mathrm{CaC} 2 \mathrm{O} 4$ & 0.0000 & $\mathrm{Mg}(\mathrm{C} 2 \mathrm{H} 3 \mathrm{O} 3) 2$ & 4.7517 & Total Solids & 423.1262 \\
\hline antifoam & 5.3401 & $\mathrm{Mg}(\mathrm{NO} 3) 2$ & 7.5748 & Measured TS & 403.8388 \\
\hline Total Insoluble & 207.4056 & $\mathrm{Mn}(\mathrm{COOH}) 2$ & 0.7901 & $\Delta(\%)$ & $4.78 \%$ \\
\hline Measured IS & 197.8112 & $\mathrm{Mn}(\mathrm{C} 2 \mathrm{H} 3 \mathrm{O} 3) 2$ & 17.7865 & & \\
\hline \multirow[t]{9}{*}{$\Delta(\%)$} & 4.85 & $\mathrm{Mn}(\mathrm{NO} 3) 2$ & 29.0985 & & \\
\hline & & $\mathrm{NaCl}$ & 0.8607 & & \\
\hline & & $\mathrm{NaF}$ & 0.0000 & & \\
\hline & & $\mathrm{NaCOOH}$ & 2.9968 & & \\
\hline & & $\mathrm{NaC} 2 \mathrm{H} 3 \mathrm{O} 3$ & 42.0329 & & \\
\hline & & NaNO3 & 72.8206 & & \\
\hline & & $\mathrm{Na} 3 \mathrm{PO} 4$ & 1.7989 & & \\
\hline & & $\mathrm{Na} 2 \mathrm{C} 2 \mathrm{O} 4$ & 3.4221 & & \\
\hline & & $\mathrm{Na} 2 \mathrm{SO} 4$ & 3.3661 & & \\
\hline
\end{tabular}


Table 2-7. Composition of Charge Reconciled 125\% Acid Stoichiometry SRAT Product.

\begin{tabular}{|c|c|c|c|c|c|}
\hline $\begin{array}{l}\text { Insoluble } \\
\text { Solids: }\end{array}$ & $\begin{array}{r}\mathrm{g} / \mathrm{L} \\
\text { slurry }\end{array}$ & Soluble Solids: & $\begin{array}{r}\mathrm{g} / \mathrm{L} \\
\text { slurry }\end{array}$ & Soluble Solids: & $\begin{array}{r}\mathrm{g} / \mathrm{L} \\
\text { slurry }\end{array}$ \\
\hline $\mathrm{Fe}(\mathrm{OH}) 3$ & 86.8310 & $\mathrm{Ca}(\mathrm{COOH}) 2$ & 0.0791 & $\mathrm{Ni}(\mathrm{COOH}) 2$ & 0.1110 \\
\hline $\mathrm{Al}(\mathrm{OH}) 3$ & 89.2031 & $\mathrm{Ca}(\mathrm{C} 2 \mathrm{H} 3 \mathrm{O} 3) 2$ & 2.9327 & $\mathrm{Ni}(\mathrm{C} 2 \mathrm{H} 3 \mathrm{O} 3) 2$ & 3.9506 \\
\hline $\mathrm{MnO} 2$ & 4.1381 & $\mathrm{Ca}(\mathrm{NO} 3) 2$ & 8.5331 & $\mathrm{Ni}(\mathrm{NO} 3) 2$ & 11.6577 \\
\hline $\mathrm{Ca}(\mathrm{OH}) 2$ & 0.0000 & $\mathrm{Fe}(\mathrm{COOH}) 3$ & 0.0756 & $\mathrm{Zn}(\mathrm{COOH}) 2$ & 0.0028 \\
\hline $\mathrm{Mg}(\mathrm{OH}) 2$ & 0.0000 & $\mathrm{Fe}(\mathrm{C} 2 \mathrm{H} 3 \mathrm{O} 3) 3$ & 2.8226 & $\mathrm{Zn}(\mathrm{C} 2 \mathrm{H} 3 \mathrm{O} 3) 2$ & 0.0986 \\
\hline $\mathrm{Ni}(\mathrm{OH}) 2$ & 2.4173 & $\mathrm{Fe}(\mathrm{NO} 3) 3$ & 8.1929 & $\mathrm{Zn}(\mathrm{NO} 3) 2$ & 0.2922 \\
\hline $\mathrm{Cr}(\mathrm{OH}) 3$ & 0.7601 & $\mathrm{Al}(\mathrm{COOH}) 3$ & 0.0541 & H4SiO4 & 0.9344 \\
\hline $\mathrm{Cu}(\mathrm{OH}) 2$ & 0.1418 & $\mathrm{Al}(\mathrm{C} 2 \mathrm{H} 3 \mathrm{O} 3) 3$ & 2.1357 & Total Soluble & 233.2725 \\
\hline $\mathrm{K} 2 \mathrm{O}$ & 0.0000 & $\mathrm{Al}(\mathrm{NO} 3) 3$ & 6.0842 & Measured SS & 214.8513 \\
\hline $\mathrm{TiO} 2$ & 0.1792 & $\mathrm{Cu}(\mathrm{COOH}) 2$ & 0.0036 & $\Delta(\%)$ & 8.5740 \\
\hline $\mathrm{SiO} 2$ & 6.6474 & $\mathrm{Cu}(\mathrm{C} 2 \mathrm{H} 3 \mathrm{O} 3) 2$ & 0.1275 & & \\
\hline $\mathrm{Sn}(\mathrm{OH}) 2$ & 0.0000 & $\mathrm{Cu}(\mathrm{NO} 3) 2$ & 0.3775 & Volatiles & \\
\hline $\mathrm{Zn}(\mathrm{OH}) 2$ & 0.1705 & $\mathrm{KCOOH}$ & 0.0125 & $\mathrm{HCOOH}$ & 0.2746 \\
\hline BaSO4 & 0.4710 & $\mathrm{KC} 2 \mathrm{H} 3 \mathrm{O} 3$ & 0.4307 & $\mathrm{C} 2 \mathrm{H} 4 \mathrm{O} 3$ & 19.7681 \\
\hline $\mathrm{ZrO} 2$ & 0.4253 & KNO3 & 1.2865 & $\mathrm{H} 2 \mathrm{O}$ & 805.6882 \\
\hline CaSO4 & 0.0000 & $\mathrm{Mg}(\mathrm{COOH}) 2$ & 0.0781 & & \\
\hline $\mathrm{CaC} 2 \mathrm{O} 4$ & 0.0000 & $\mathrm{Mg}(\mathrm{C} 2 \mathrm{H} 3 \mathrm{O} 3) 2$ & 3.0214 & Total Solids & 429.5691 \\
\hline antifoam & 4.9118 & $\mathrm{Mg}(\mathrm{NO} 3) 2$ & 8.6646 & Measured TS & 411.3726 \\
\hline Total Insoluble & 196.2966 & $\mathrm{Mn}(\mathrm{COOH}) 2$ & 0.2940 & $\Delta(\%)$ & $4.42 \%$ \\
\hline Measured IS & 196.5213 & $\mathrm{Mn}(\mathrm{C} 2 \mathrm{H} 3 \mathrm{O} 3) 2$ & 10.5461 & & \\
\hline \multirow[t]{9}{*}{$\Delta(\%)$} & -0.11 & $\mathrm{Mn}(\mathrm{NO} 3) 2$ & 31.0385 & & \\
\hline & & $\mathrm{NaCl}$ & 0.0000 & & \\
\hline & & $\mathrm{NaF}$ & 0.0000 & & \\
\hline & & $\mathrm{NaCOOH}$ & 0.9120 & & \\
\hline & & $\mathrm{NaC} 2 \mathrm{H} 3 \mathrm{O} 3$ & 31.0162 & & \\
\hline & & NaNO3 & 89.4127 & & \\
\hline & & $\mathrm{Na} 3 \mathrm{PO} 4$ & 1.7345 & & \\
\hline & & $\mathrm{Na} 2 \mathrm{C} 2 \mathrm{O} 4$ & 3.2934 & & \\
\hline & & $\mathrm{Na} 2 \mathrm{SO} 4$ & 3.0653 & & \\
\hline
\end{tabular}

\subsubsection{Remediation and Frit Addition}

The charge-reconciled SRAT product compositions shown in Table 2-6 and Table 2-7 were next remediated in order to reduce the observed discrepancies between the redox of as-received SRAT products and their targets. Specifically, the $100 \%$ acid stoichiometry SRAT product was made more oxidizing by adding $2.0 \mathrm{~kg}$ of $49.4 \mathrm{wt} \%$ nitric acid to each drum containing $170 \mathrm{lb}$ of SRAT product following the strategy shown in Table 2-8; its redox measured in a closed crucible was decreased from 0.47 to 0.25 after remediation. For the $125 \%$ acid stoichiometry SRAT product, $1.5 \mathrm{~kg}$ of $70 \mathrm{wt} \%$ glycolic acid was added to each drum containing $200 \mathrm{lb}$ of SRAT product, and the redox was increased from $<0.02$ to 0.25 after remediation. Frit 418 was added along with the acids at the target of $36 \mathrm{wt} \%$ waste loading (WL). The remediated products at $45 \%$ total solids were fed during the Phase 2 steady state runs, while the $100 \%$ acid stoichiometry feed at $42 \%$ total solids was fed during the surge testing. 
Table 2-8. Remediation Strategy and Frit Addition.

\begin{tabular}{|l|r|r|r|}
\hline Acid Stoichiometry & $\mathbf{1 0 0} \%$ & $\mathbf{1 0 0} \%$ & $\mathbf{1 2 5} \%$ \\
\hline Target Total Solids (wt\%) & 45 & 42 & 45 \\
\hline Target Waste Loading (wt\%) & 36 & 36 & 36 \\
\hline Drum Mass (lb) & 184 & 184 & 214 \\
\hline Drum Tare (lb) & 14 & 14 & 14 \\
\hline SRAT Product Mass (lb) & 170 & 170 & 200 \\
\hline Frit 418 added (kg/drum) & 24.7 & 24.7 & 28.6 \\
\hline Nitric Acid added (kg/drum) & 2 & 2 & 0 \\
\hline - strength (wt\%) & 49.4 & 49.4 & 49.4 \\
\hline Glycolic Acid added (kg/drum) & 0 & 0 & 1.5 \\
\hline - strength (wt\%) & 70 & 70 & 70 \\
\hline $\mathrm{H}_{2} \mathrm{O}$ added (kg/drum) & 8.4 & 19.7 & 10.5 \\
\hline Redox (closed crucible) & & & \\
\hline - before remediation & 0.47 & 0.47 & $<0.02$ \\
\hline - after remediation & 0.25 & 0.25 & 0.25 \\
\hline $\mathrm{pH}$ & & & \\
\hline - before remediation & 5.03 & - & 3.21 \\
\hline - after remediation \& frit addition & 3.82 & - & 3.34 \\
\hline
\end{tabular}

\subsubsection{Final Adjustment of Feeds}

Although the as-received SRAT products were charge reconciled using the anion data by AD and remediated simply by adding acids and frit, the analytical results of the remediated feeds showed that the calculated glycolate concentrations were still lower than the measured data by AD. As a result, an additional $13.5 \%$ and $7 \%$ glycolic acid had to be added to the $100 \%$ and $125 \%$ acid stoichiometry feeds, respectively, in order to match the AD results. Once additional glycolic acid was added, the equilibrium free acid calculation was performed again at the measured $\mathrm{pH}$ values of the remediated feeds shown in Table 2-8. To do so, a correlation between free acid fraction of $\mathrm{C}_{2} \mathrm{H}_{4} \mathrm{O}_{3}$ and $\mathrm{pH}$ was derived by extrapolating the results of SRAT product charge reconciliation to $\mathrm{pH}=7$ where the fraction was set to zero and to $\mathrm{pH}=0$, where the fraction was set to 1 , as shown in Figure 2-1:

$$
\text { Frac }_{\text {free GA }}=0.019 p H^{2}-0.276 p H+0.9996
$$

Eq. (1) can be used to predict the free acid fraction at varying SRAT or SME pH, as long as the $\mathrm{pH}$ does not drop too much below 2, which is expected to be the case for the NGA flowsheet feeds. Use of Eq. (1) simplified the process of re-distributing both existing and added glycolic acid significantly. It turns out that for the $100 \%$ acid stoichiometry feed there was not enough free glycolic acid to satisfy the equilibrium demand at $\mathrm{pH}=3.82$, thus necessitating the conversion of glycolate salts into nitrate salts at the expense of nitric acid as follows:

$$
\mathrm{NaC}_{2} \mathrm{H}_{3} \mathrm{O}_{3}+\mathrm{HNO}_{3} \rightarrow \mathrm{NaNO}_{3}+\mathrm{C}_{2} \mathrm{H}_{4} \mathrm{O}_{3}
$$

No such acid shortage occurred to the $125 \%$ acid stoichiometry feed because it was remediated by adding additional glycolic acid. 


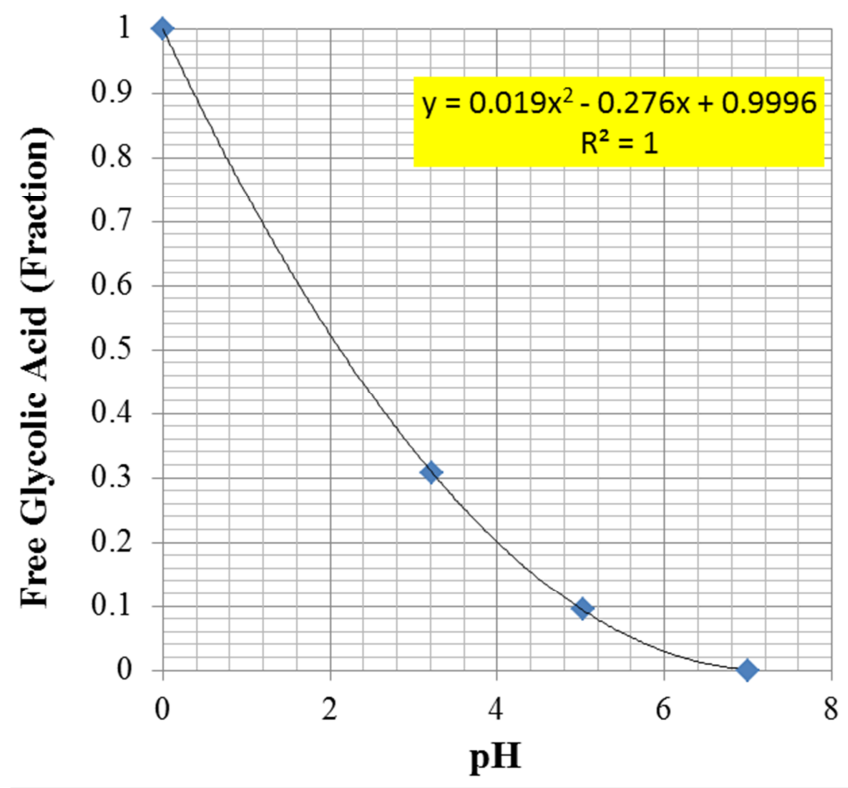

Figure 2-1. Free Acid Fraction of Glycolate vs. pH.

The nitrate and glycolate in the final $100 \%$ and $125 \%$ acid stoichiometry feeds used in Phase 2 are compared in Table 2-9 along with the TOC distributions. The two main anions match their respective measured data within $\sim 1 \%$. However, the calculated TOC is still shown to be $18 \%$ and $10 \%$ lower than the measured data. If the underestimation of TOC is real, the current analysis to derive the global kinetic parameters using the underestimated TOC input is conservative because the $\mathrm{CO}$ and $\mathrm{H}_{2}$ concentrations in the off-gas are fixed by the measured data regardless.

Table 2-9. Comparison of Final $100 \%$ and $125 \%$ Acid Stoichiometry Feeds.

\begin{tabular}{|l|r|r|}
\hline & $\begin{array}{r}100 \% \text { Acid } \\
(\mathrm{mg} / \mathrm{kg})\end{array}$ & $\begin{array}{r}125 \% \text { Acid } \\
(\mathrm{mg} / \mathrm{kg})\end{array}$ \\
\hline $\mathrm{NO}_{3}$ & \multicolumn{2}{|r|}{} \\
\hline - calculated & 58,765 & 66,774 \\
\hline - measured by AD & 58,804 & 67,341 \\
\hline $\mathrm{C}_{2} \mathrm{H}_{3} \mathrm{O}_{3}$ total & & \\
\hline - calculated & 34,494 & 42,765 \\
\hline - measured by AD & 34,665 & 43,250 \\
\hline - $\mathrm{C}_{2} \mathrm{H}_{3} \mathrm{O}_{3}$ (free) & 7,793 & 12,606 \\
\hline TOC & \multicolumn{2}{|}{} \\
\hline - calculated & 13,322 & 15,573 \\
\hline - measured by DWPF & 16,199 & 17,343 \\
\hline - $\Delta$ TOC (calc'd - DWPF) & $-17.8 \%$ & $-10.2 \%$ \\
\hline TOC Distributions: & \multicolumn{2}{|}{} \\
\hline - formate & 427 & 159 \\
\hline - glycolate & 9,987 & 7,730 \\
\hline - oxalate & 337 & 325 \\
\hline - free formic & 40 & 39 \\
\hline - free glycolic & 1,055 & 5,959 \\
\hline - antifoam & 1,476 & 1,360 \\
\hline
\end{tabular}




\subsection{Phase 2 Data}

The Phase 2 CEF run proceeded in 3 stages. In the first stage, a total of 24 steady state runs were made by feeding each acid stoichiometry feed (100\% and 125\%) at 6 different CEF vapor space temperatures under bubbled (B) and non-bubbled (NB) conditions. For example, the 100\%_B_1X run produced steady state data with the $100 \%$ acid stoichiometry feed containing normal $(1 \mathrm{X})$ level of antifoam at 6 different vapor space temperatures under bubbled conditions. In Stage 2, the CEF was run with the $100 \%$ acid stoichiometry feed containing normal (1X) level of antifoam for 4 days under bubbled and for 1 day under non-bubble conditions to collect off-gas surge data. In Stage 3, the CEF was run with the $100 \%$ acid stoichiometry feed containing $2 \mathrm{X}$ the normal level of antifoam under non-bubbled conditions, while maintaining the vapor space at 6 different temperatures (100\%_NB_2X). A detailed description of the Phase 2 run is given elsewhere along with the full set of data on the CEF and off-gas system parameters, off-gas analysis and analytical results on the feed, glass, and condensate samples. ${ }^{3}$

\subsubsection{Steady State Data}

The average readings of some of the key CEF operating variables taken during the Phase 2 steady state runs are given in Table 2-10 along with those of the major off-gas species detected. Out of the 24 steady state data sets collected in Stage 1, three were discarded due to either poor carbon balance or large fluctuations in data; they were $100 \%$ B_1X at $400{ }^{\circ} \mathrm{C}$ and $125 \%$ NB_1X at 500 and $600{ }^{\circ} \mathrm{C}$. Table $2-10$ also contains 6 steady state data sets from the $100 \%$ NB_2X run. A more complete list of steady state data is given in Appendix, including additional $\mathrm{H}_{2}$ data by $\mathrm{GC}$ and $\mathrm{CO}_{2}$ data by both $\mathrm{GC}$ and FTIR along with the standard deviation of each average data. Methane was also monitored but its concentration was less than $10 \mathrm{ppm}$ throughout except during the $100 \%$ NB_2X run at $600{ }^{\circ} \mathrm{C}$. No other flammable gases were detected besides $\mathrm{H}_{2}, \mathrm{CO}$ and $\mathrm{CH}_{4}$.

At a given vapor space (VS) temperature, measured $\mathrm{H}_{2}$ and $\mathrm{CO}$ readings were both higher under bubbled than non-bubbled conditions. This was expected because the steady state feed rates were higher under bubbled than non-bubbled at comparable VS temperatures, which translated into higher $\mathrm{H}_{2}$ and $\mathrm{CO}$ readings at comparable air purge rates. Bubbling with argon is known to make glass reducing; ${ }^{17}$ however, it was not possible to conclude from the Phase 2 data that the reducing effect by argon-bubbling actually caused off-gas to become more flammable. It is noted that these $\mathrm{H}_{2}$ readings are $\sim 1 / 5$ of those taken with the NFA flowsheet feed. For example, at $\sim 600{ }^{\circ} \mathrm{C}$, the average $\mathrm{H}_{2}$ reading in Phase 1 was $117 \mathrm{ppm}$, compared to $23 \mathrm{ppm}$ in the 100\%_NB_1X run.

It is also noted that the $\mathrm{H}_{2}$ evolution from the $100 \%$ NB_2X run was practically indistinguishable from that from the $100 \%$ NB_1X run except at $\sim 600{ }^{\circ} \overline{\mathrm{C}}$ and in general lower than that from the $125 \%$ NB_1X run. This somewhat surprising result that doubling the antifoam did not have any appreciable effect on $\mathrm{H}_{2}$ is, however, consistent with the results from the batch-melting study in an argon-purged crucible shown in Figure 2-2. ${ }^{14}$

Both $\mathrm{H}_{2}$ and $\mathrm{CO}$ readings are shown to decrease with decreasing VS temperature below $\sim 600{ }^{\circ} \mathrm{C}$, and this is a reflection of the net effect of several competing changes occurring simultaneously. First, as the VS temperature decreased, the steady state feed rate decreased, which would lower the $\mathrm{H}_{2}$ and $\mathrm{CO}$ readings, as noted above. Second, as the VS temperature decreased, the global combustion kinetics would slow down, resulting in higher $\mathrm{H}_{2}$ and $\mathrm{CO}$ readings. Third, as the air purge into the vapor space was increased steadily to lower the VS temperature below $\sim 500{ }^{\circ} \mathrm{C}$, the $\mathrm{H}_{2}$ and $\mathrm{CO}$ readings would decrease by dilution but the shortened gas residence time for the VS combustion would increase them at the same time. Thus, the analysis of $\mathrm{H}_{2}$ and $\mathrm{CO}$ data is not straightforward; it requires a comprehensive mass/heat balance model of the CEF and off-gas system, as shown later in the report. 
Table 2-10. Average CEF Operating and Off-Gas Data During Phase 2 Steady State Runs.

\begin{tabular}{|c|c|c|c|c|c|c|c|c|c|c|c|c|c|c|}
\hline SS Run & $\begin{array}{c}\text { VS } \\
\text { Temp } \\
\left({ }^{\circ} \mathrm{C}\right)\end{array}$ & $\begin{array}{l}\text { Feed } \\
\text { Rate } \\
\text { (g/min) }\end{array}$ & $\begin{array}{l}\text { FC Air } \\
\text { (scfm) }\end{array}$ & $\begin{array}{c}\text { Purge } \\
\text { Air } \\
\text { (scfm) }\end{array}$ & $\begin{array}{c}\text { FC } \\
\text { Exit T } \\
\left({ }^{\circ} \mathrm{C}\right)\end{array}$ & $\begin{array}{c}\text { Melter } \\
\text { P } \\
\text { ("H2O) }\end{array}$ & $\begin{array}{c}\text { FC } \\
\text { Exit P } \\
\text { ("H2O) }\end{array}$ & $\begin{array}{c}\text { Glass } \\
\text { Temp } \\
\left({ }^{\circ} \mathrm{C}\right)\end{array}$ & $\begin{array}{c}\mathrm{H}_{2} \\
(\mathrm{MS}) \\
\text { (ppm) }\end{array}$ & $\begin{array}{c}\text { CO } \\
\text { (FTIR) } \\
\text { (ppm) }\end{array}$ & $\begin{array}{c}\mathrm{CO}_{2} \\
(\mathrm{MS}) \\
(\mathrm{vol} \%)\end{array}$ & $\begin{array}{c}\text { NO } \\
\text { (MS) } \\
\text { (ppm) }\end{array}$ & $\begin{array}{c}\mathrm{NO}_{2} \\
\text { (MS) } \\
\text { (ppm) }\end{array}$ & $\begin{array}{c}\mathrm{N}_{2} \mathrm{O} \\
(\mathrm{FTIR}) \\
(\mathrm{ppm})\end{array}$ \\
\hline \multirow{6}{*}{ 125\%_B_1X } & 705 & 221 & 15.64 & 0.65 & 366 & -5.22 & -5.97 & 1,033 & 43 & 224 & 0.919 & 2,183 & 1,430 & 391 \\
\hline & 625 & 161 & 15.92 & 0.68 & 299 & -5.35 & -5.99 & 1,032 & 70 & 180 & 0.676 & 1,898 & 981 & 266 \\
\hline & 481 & 114 & 15.88 & 15.12 & 256 & -4.90 & -6.20 & 1,025 & 42 & 32 & 0.312 & 917 & 388 & 106 \\
\hline & 415 & 111 & 16.08 & 22.28 & 234 & -4.74 & -6.42 & 1,029 & 28 & 23 & 0.245 & 793 & 364 & 90 \\
\hline & 360 & 93 & 8.54 & 40.14 & 244 & -3.48 & -5.91 & 1,011 & 18 & 22 & 0.183 & 498 & 228 & 68 \\
\hline & 270 & 72 & 6.20 & 50.68 & 203 & -1.16 & -3.85 & 1,035 & 19 & 19 & 0.162 & 441 & 184 & 59 \\
\hline \multirow{4}{*}{ 125\%_NB_1X } & 709 & 100 & 15.73 & 0.45 & 325 & -5.47 & -6.02 & 1,083 & 13 & 119 & 0.431 & 1,360 & 607 & 219 \\
\hline & 393 & 51 & 15.73 & 14.98 & 212 & -5.46 & -6.56 & 1,085 & 23 & 14 & 0.189 & 517 & 275 & 75 \\
\hline & 351 & 44 & 15.93 & 20.89 & 200 & -5.04 & -6.43 & 1,083 & 16 & 11 & 0.157 & 374 & 279 & 56 \\
\hline & 302 & 35 & 15.91 & 29.62 & 183 & -4.96 & -6.81 & 1,084 & 12 & 6 & 0.119 & 332 & 213 & 32 \\
\hline \multirow{5}{*}{ 100\%_B_1X } & 705 & 170 & 15.25 & 0.52 & 358 & -4.81 & -5.50 & 1,050 & 19 & 161 & 0.659 & 1,947 & 1,091 & 220 \\
\hline & 592 & 146 & 15.32 & 0.51 & 285 & -4.66 & -5.25 & 1,042 & 37 & 109 & 0.512 & 1,682 & 866 & 165 \\
\hline & 471 & 123 & 15.32 & 6.09 & 235 & -4.42 & -5.22 & 1,041 & 31 & 55 & 0.399 & 1,303 & 673 & 115 \\
\hline & 373 & 102 & 15.50 & 25.94 & 219 & -5.06 & -6.96 & 1,025 & 18 & 20 & 0.218 & 689 & 340 & 56 \\
\hline & 323 & 88 & 6.12 & 45.90 & 224 & -1.13 & -3.61 & 1,031 & 13 & 18 & 0.130 & 545 & 268 & 674 \\
\hline \multirow{6}{*}{$100 \%$ NB_1X } & 697 & 125 & 16.14 & 0.32 & 323 & -5.27 & -5.77 & 1,086 & 17 & 117 & 0.476 & 1,445 & 671 & 152 \\
\hline & 600 & 99 & 16.55 & 0.32 & 268 & -5.70 & -6.15 & 1,085 & 23 & 85 & 0.355 & 1,137 & 518 & 125 \\
\hline & 496 & 84 & 16.80 & 0.33 & 214 & -6.00 & -6.42 & 1,068 & 19 & 26 & 0.297 & 993 & 455 & 96 \\
\hline & 410 & 56 & 16.83 & 13.22 & 209 & -5.46 & -6.49 & 1,074 & 7 & 8 & 0.121 & 502 & 244 & 634 \\
\hline & 344 & 48 & 16.10 & 27.93 & 201 & -4.46 & -6.28 & 1,078 & 6 & 4 & 0.094 & 307 & 196 & 364 \\
\hline & 326 & 42 & 9.67 & 34.77 & 217 & -4.02 & -5.99 & 1,079 & 6 & 4 & 0.095 & 284 & 252 & 348 \\
\hline \multirow{6}{*}{$100 \%$ NB_2X } & 722 & 103 & 16.14 & 0.19 & 334 & -2.92 & -3.67 & 1,097 & 6 & 154 & 0.577 & 0.527 & 0.590 & 1,522 \\
\hline & 604 & 47 & 15.97 & 0.41 & 292 & -5.38 & -6.14 & 1,071 & 60 & 213 & 0.484 & 0.457 & 0.493 & 1,300 \\
\hline & 519 & 57 & 15.99 & 0.42 & 222 & -5.12 & -5.77 & 1,066 & 10 & 89 & 0.256 & 0.252 & 0.267 & 787 \\
\hline & 397 & 49 & 15.85 & 19.00 & 211 & -4.63 & -6.29 & 1,052 & 9 & 51 & 0.155 & 0.159 & 0.164 & 392 \\
\hline & 323 & 39 & 10.01 & 27.97 & 211 & -4.04 & -5.97 & 1,067 & 9 & 22 & 0.118 & 0.131 & 0.126 & 287 \\
\hline & 293 & 37 & 5.69 & 34.39 & 227 & -2.80 & -4.88 & 1,066 & 10 & 27 & 0.110 & 0.119 & 0.118 & 243 \\
\hline
\end{tabular}


SRNL-STI-2014-00355

Revision 0

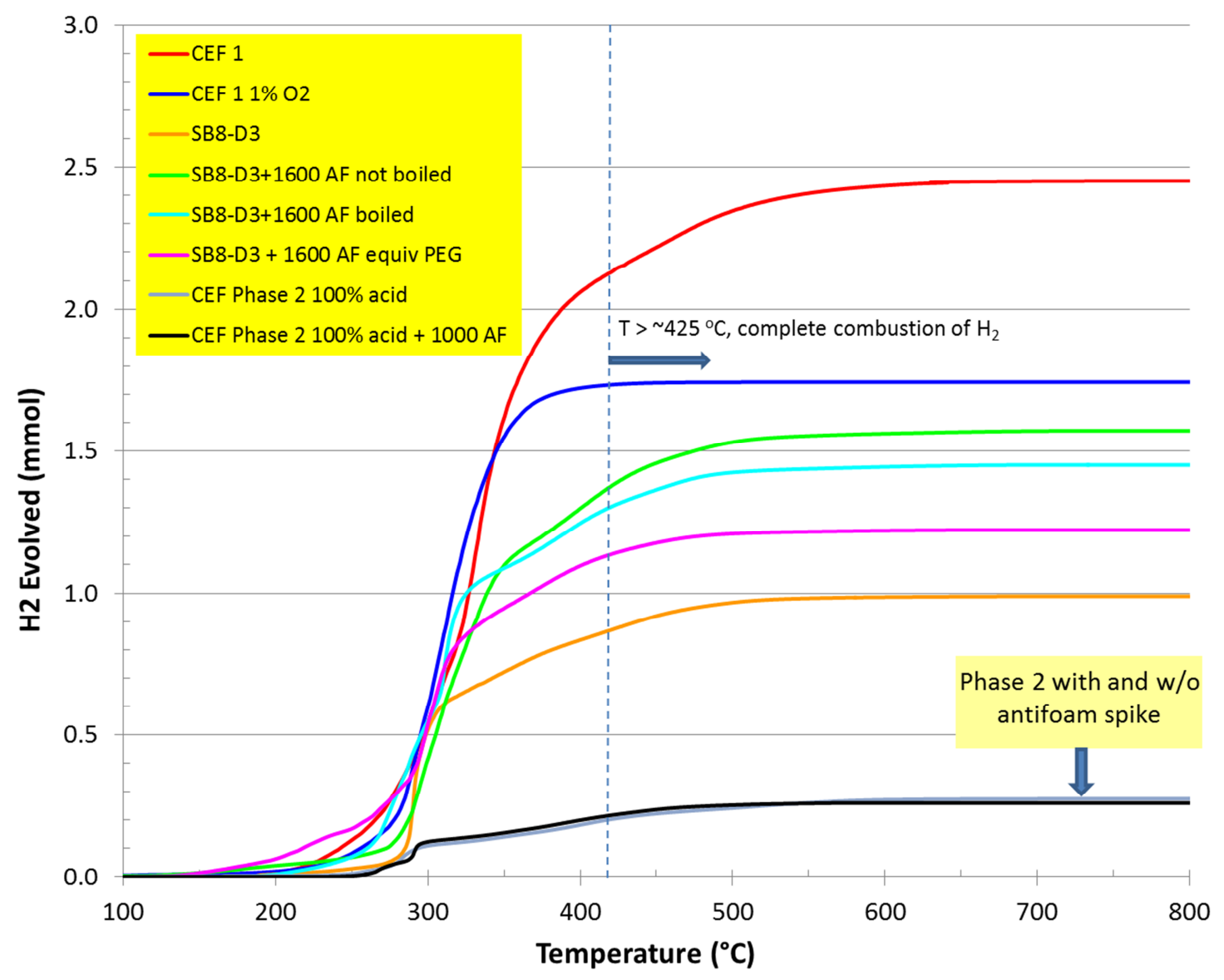

Figure 2-2. Cumulative $\mathrm{H}_{2}$ Evolution during Batch-Melting in Ar-Purged Crucible. ${ }^{14}$

\subsubsection{Off-Gas Surge Data}

The number of pressure spikes measured during Phase 2 is compared to that of the 2010 CEF run in Table 2-11. It is clearly seen that under bubbled conditions the NGA flowsheet feed produced pressure spikes $<2$ " $\mathrm{H}_{2} \mathrm{O}$ at an order of magnitude higher frequency than the NFA flowsheet feed used in 2010. However, pressure spikes of these small magnitudes are not expected to pose any significant operational difficulties in the DWPF, especially considering the fact that the DWPF melter is equipped with a fast-acting pressure control system. Note that the CEF pressure spike data in Table 2-11 was obtained in the absence of pressure control system and thus unmodulated, which enabled the surge magnitudes to be calculated directly from the measured pressure drop and off-gas data, as shown later in the report.

By contrast, the NGA flowsheet feeds produced almost no pressure spikes under non-bubbled conditions, whereas the difference between bubbled and non-bubbled pressure spike frequencies of the 2010 run with the NFA flowsheet feed is shown to be not nearly as large. However, considering that a majority of the reported pressure spikes for the 2010 run occurred while the system components were still being checked out and fine-tuned, the actual difference between bubbled and non-bubbled spikes of the NFA flowsheet feed was likely to be larger than the data shown in Table 2-11. ${ }^{6}$ One of the two rare pressure spikes measured during the non-bubbled surge test was in excess of 5" $\mathrm{H}_{2} \mathrm{O}$ but lasted for only 13 seconds, which is too short a duration to have any impact on the off-gas flammability. 
Table 2-11. Number of Pressure Spikes during CEF Runs.

\begin{tabular}{|c|c|c|c|c|}
\hline \multirow{2}{*}{$\begin{array}{c}\text { Pressure Spike } \\
\text { above Baseline } \\
\left(\text { ("H } \mathrm{H}_{2} \mathrm{O}\right)\end{array}$} & \multicolumn{2}{|c|}{ Bubbled } & \multicolumn{2}{c|}{ Non-bubbled } \\
\cline { 2 - 5 } & Formic & Glycolic & Formic & Glycolic \\
\hline $1-2$ & 2010 & 2014 & 2010 & 2014 \\
\hline $2-3$ & 42 & 1,164 & 28 & 1 \\
\hline $3-4$ & 27 & 15 & 3 & 0 \\
\hline $4-5$ & 7 & 6 & 1 & 0 \\
\hline$>5$ & 18 & 14 & 0 & 1 \\
\hline Total & 192 & 1,242 & 47 & 2 \\
\hline Test Duration (day) & 4.3 & 4 & 2.5 & 1 \\
\hline Frequency (\#/day) & 45 & 311 & 19 & 2 \\
\hline
\end{tabular}

The NGA flowsheet feed produced pressure spikes $>2$ " $\mathrm{H}_{2} \mathrm{O}$ at about the same frequency as the NFA flowsheet feed, including those $>5{ }^{\prime} \mathrm{H}_{2} \mathrm{O}$, and the largest pressure spike measured during Phase 2 under bubbled conditions was in excess of 13 " $\mathrm{H}_{2} \mathrm{O}$ from the baseline -5 to +8.3 " $\mathrm{H}_{2} \mathrm{O}$, as shown in Figure 2-3. By comparison, the largest pressure spike measured during the $2010 \mathrm{CEF}$ run was $10 " \mathrm{H}_{2} \mathrm{O}$ from baseline -5 to $+5 " \mathrm{H}_{2} \mathrm{O}$, which was subsequently used to set the current off-gas surge basis of $9 \mathrm{X}$ normal condensable and $5 \mathrm{X}$ normal non-condensable flows $(9 \mathrm{X} / 5 \mathrm{X})$.

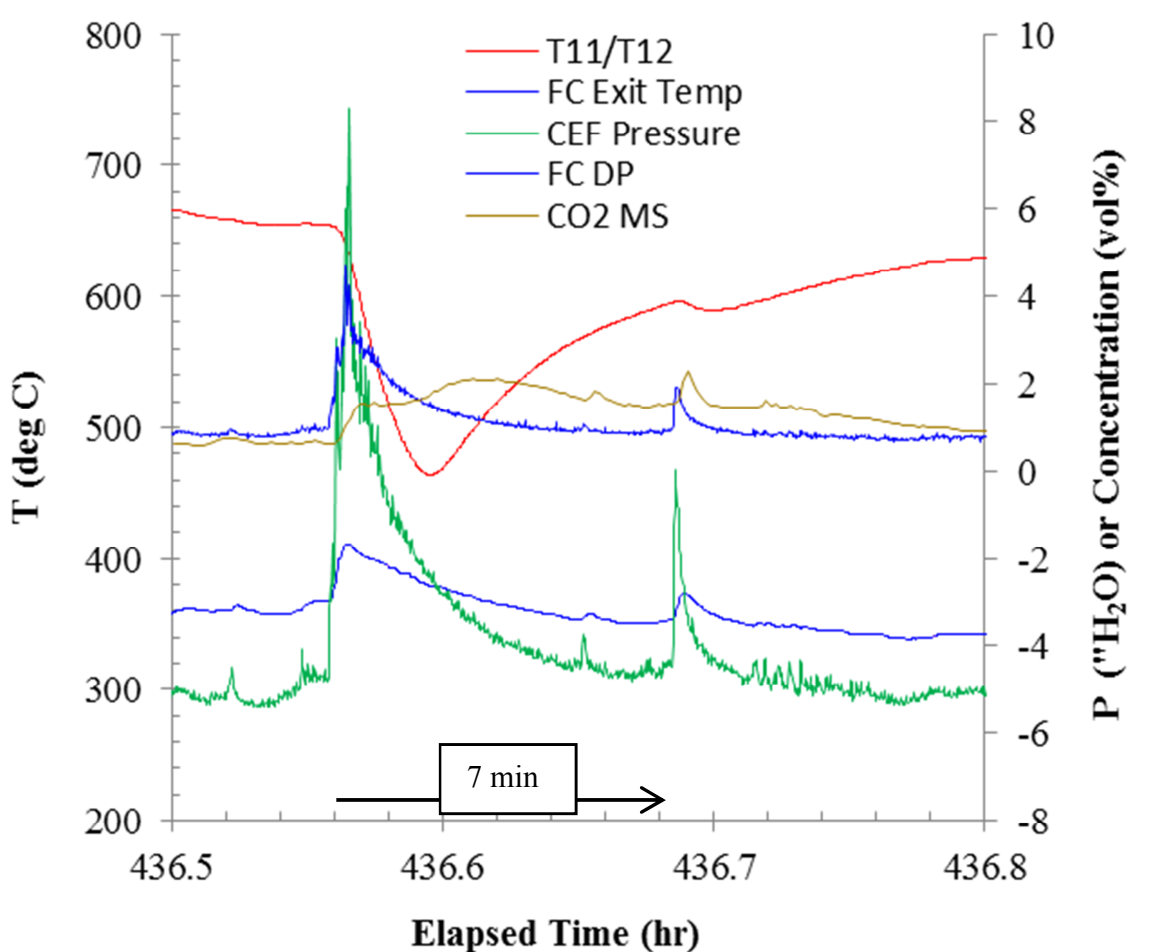

Figure 2-3. 13" $\mathrm{H}_{2} \mathrm{O}$ Pressure Spike during Phase 2 Bubbled Test at $700{ }^{\circ} \mathrm{C}$. 
In fact, an even larger pressure spike in excess of 20 " $\mathrm{H}_{2} \mathrm{O}$ also occurred during Phase 2; however, its duration of 5 seconds was too short to have any impact on the off-gas flammability or trigger a switchover to the backup off-gas system according the current DCS logic. Regarding the 13 " $\mathrm{H}_{2} \mathrm{O}$ pressure spike shown in Figure 2-3, its key attributes such as the instantaneous ascend at the onset but the more gradual decent from the peak over the next several minutes match well those of the current DWPF melter off-gas flammability safety basis off-gas surge profile:

- At time zero, the flow rates of condensable and non-condensable gases instantly increase to 9 times (9X) and 5 times (5X) the nominal, respectively, then immediately decrease linearly to $30 \%$ of their respective peak values during the first minute and further decrease linearly to 1.0 times the normal values (1X) during the next 7 minutes.

As expected, the VS temperature fell significantly, e.g. by $\sim 200{ }^{\circ} \mathrm{C}$, due to a surge of steam from the cold cap, while the concentration of $\mathrm{CO}_{2}$ in the off-gas went up from the baseline value of $0.65 \%$ to $2.3 \%$, which is regarded as a measure of the non-condensable surge. Therefore, the largest pressure spike of $13 " \mathrm{H}_{2} \mathrm{O}$ during Phase 2 will be designated as the baseline off-gas surge for the bubbled NGA flowsheet operation.

The accompanying profiles of pressure drop $(\Delta \mathrm{P})$ across the film cooler and $\mathrm{CO}_{2}$ in the off-gas shown in Figure 2-4 were be used as the basis for determining the magnitudes of condensable and non-condensable surges, respectively, for bubbled operation, as shown later in the mass and heat balance section of the report. Both Figure 2-3 and Figure 2-4 show a second smaller peak $\sim 8$ min after the first; it is not counted as part of the large surge but as a separate surge. It is this second pressure spike that clearly shows a time delay in the response of $\mathrm{CO}_{2}$ readings, which is estimated to be 17 seconds. The time delay in the response of the VS temperature is estimated to be much longer at 1 minute 49 seconds.

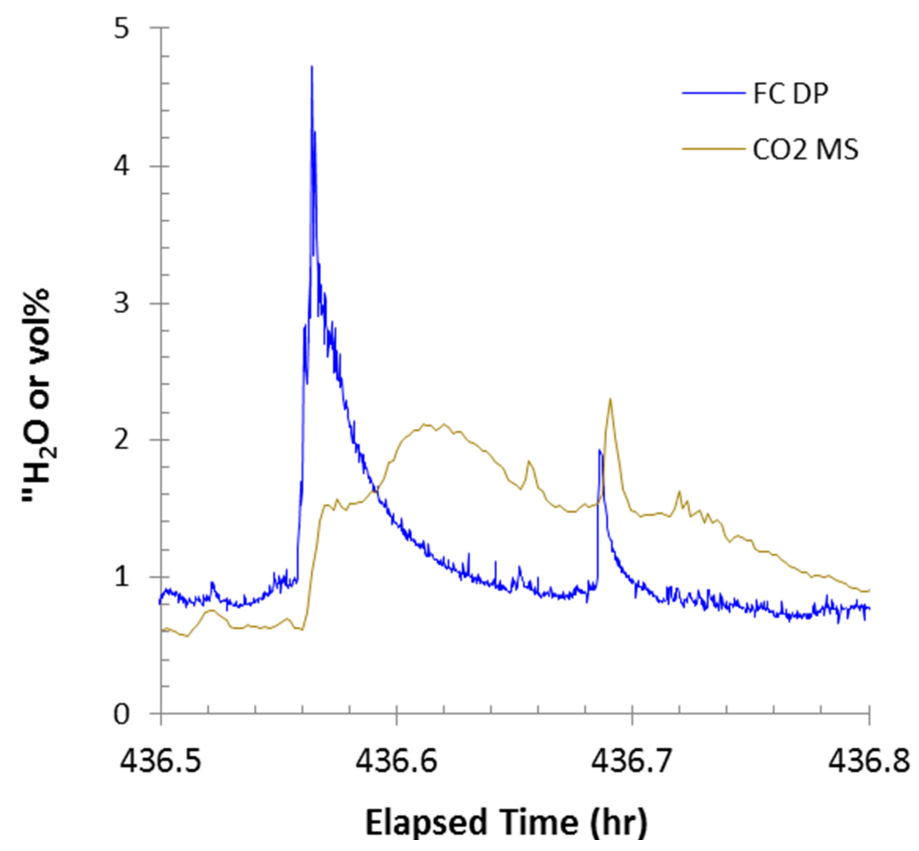

Figure 2-4. Profiles of Film Cooler $\Delta \mathrm{P}$ and $\mathrm{CO}_{2}$ during 13 ” $\mathrm{H}_{2} \mathrm{O}$ Pressure Spike. 
It is noted that the feed rates used in the $2010 \mathrm{CEF}$ run was $\sim 50 \%$ higher than those used in Phase 2 partly because the CEF was run at $\sim 50$ to $100{ }^{\circ} \mathrm{C}$ higher VS temperatures. Nevertheless, the CEF was definitely pushed harder in 2010 in terms of feed rate because the ability to visually monitor the cold cap to prevent potential overfeeding was non-existent. It means that had the CEF been run the same way as it was in Phase 2, the pressure spikes measured in 2010 would have been smaller and less frequent, which in turn would have made the greater surging tendency of the NGA flowsheet feed more evident in terms of both magnitude and frequency. Increased surging tendency of the NGA flowsheet feed is likely due to its excess nitrate decomposing and thus generating large volumes of calcine gases all over the cold cap.

\subsection{DWPF Melter Off-Gas Flammability Model}

\subsection{Original Model}

The DWPF melter off-gas flammability model has been in use since the radioactive startup in 1996 to define the melter operating window for a given sludge batch in the form of Technical Safety Requirements (TSR) and feed interlocks. ${ }^{11}$ It consists of two sub-models; the first model, called the 4-stage cold cap model, thermodynamically describes the chemistry of calcination and fusion reactions and calculates the compositions of two end products, calcine gases and glass, from a given feed composition. The model was developed based on the Scale Glass Melter $9^{\text {th }}$ campaign (SGM-9) data and validated against the data from two smaller-scale melters. ${ }^{18}$ The calculated composition of calcine gases is then used as the input to the second model, called the melter off-gas (MOG) dynamics model, which predicts the transient behavior of the DWPF MOG system under various upset scenarios. ${ }^{19}$ Embedded in the MOG dynamics model is the vapor space combustion module that calculates the time-dependent concentrations of flammable gases in the melter exhaust using a global kinetics scheme to predict the off-gas flammability potential downstream. The baseline upset scenario for the flammability safety analysis is an off-gas surge, which depends on the feed chemistry as well as the melter operating mode. ${ }^{6}$

\subsection{Current Model}

It is noted that the original model was developed and validated using the data produced with the NFA flowsheet feeds that contained much smaller quantities of antifoam than used now and little free formic acid. The scope of the original model was expanded in 2011 to account for the presence of significant levels of antifoam and free (undissociated) formic acid in the feed and their impact on the off-gas flammability. Specifically, a 2-step antifoam decomposition scheme was added to the cold cap model ${ }^{16}$ while formic acid was allowed to decompose via two parallel routes in the melter vapor space. ${ }^{4}$ The resulting model bounded both $\mathrm{H}_{2}$ and $\mathrm{CO}$ data taken during Phase 1. In doing so, however, it over predicted the TOC-to- $\mathrm{H}_{2}$ conversion by a factor of 4 or higher at $\mathrm{T}_{\text {gas }}<\sim 350^{\circ} \mathrm{C}$, which was attributed to the conservative antifoam decomposition scheme used in the cold cap model. ${ }^{8}$

\subsection{New Model}

The flowsheet change to be addressed in the new model is in the chemistry of cold cap and vapor space reactions involving glycolate and its decomposition products. The strategy used to develop a new model for the NGA flowsheet feed was to preserve the original 4-stage cold cap model construct, introduce new model parameters and reaction schemes to reflect the impact of the NGA flowsheet chemistry, and address the shortcomings found in the current model including the conservative antifoam decomposition scheme. 


\subsubsection{Fractional Removal of Nitrate}

An earlier cold cap model run showed that the excess nitrate in the NGA flowsheet feed would oxidize all $\mathrm{H}_{2}$ and $\mathrm{CO}$, thus rendering the resulting calcine gases non-flammable, despite their presence in the off-gas at low but non-zero concentrations. ${ }^{4}$ Low concentrations of $\mathrm{H}_{2}$ and $\mathrm{CO}$ in the off-gas was confirmed in Phase 2 (see Table 2-10) and also during the crucible test, as shown in Figure 2-2 in comparison to the NFA flowsheet feeds. This new parameter sets a portion of nitrate in the feed to be excluded from the cold cap model input, thus effectively reducing its oxidizing potential. Specifically, it is $\mathrm{N}_{2} \mathrm{O}_{5}$ that gets removed from the input due to its volatility:

$$
2 \mathrm{NaNO}_{3} \rightarrow \mathrm{Na}_{2} \mathrm{O}+\mathrm{N}_{2} \mathrm{O}_{5}
$$

The gaseous product $\mathrm{N}_{2} \mathrm{O}_{5}$ is made up of $\mathrm{NO}_{2}$ and $\mathrm{NO}_{3}$, the latter further decomposes to $\mathrm{NO}$ and $\mathrm{O}_{2}$. The physical justification for this parameter is that since nitrate is present at such a high concentration in the feed, it is conceivable that some fraction of it decomposes and leaves the cold cap without fully imparting its oxidizing power on other feed constituents. This scheme is similar to employing a bypassing mechanism frequently done to model the non-ideal mixing in real processes. The fraction of nitrate to be removed was determined iteratively by matching as closely as possible the calculated concentrations of $\mathrm{H}_{2}$ and $\mathrm{CO}$ at an assumed removal fraction with those measured at the lowest vapor space temperatures at near $300{ }^{\circ} \mathrm{C}$ or lower during each series of steady state runs.

\subsubsection{Fractional Conversion of Glycolic Acid Decomposition}

As shown in Table 2-8, the remediated Phase 2 feeds were quite acidic, the $\mathrm{pH}$ ranging from 3.07 to 3.86. At this acidic condition, a significant portion of the measured glycolate is in the free acid form that can easily decompose or even volatilize (see Figure 2-1). The decomposition of free glycolic acid was modeled using the following stoichiometry:

$$
\mathrm{C}_{2} \mathrm{H}_{4} \mathrm{O}_{2} \rightarrow 2 \mathrm{CO}+\mathrm{H}_{2}+\mathrm{H}_{2} \mathrm{O}
$$

Eq. (4) is not modeled as part of the cold cap reactions, although in reality a major portion of free glycolic acid may decompose in the cold cap. However, since free glycolic acid decomposes at low temperatures, e.g. at $\sim 112{ }^{\circ} \mathrm{C}$ for $70 \%$ solution, it was assumed that it decomposes quickly upon entering the melter and exits the cold cap along with other volatile components of the feed.

The fractional conversion of Eq. (4) was set by iteratively matching the calculated concentration of $\mathrm{CO}$ with $125 \%$ of the measured data at each steady state temperature using the existing global kinetic parameters of $\mathrm{CO}$ combustion. The fractional conversions thus determined as a function of VS gas temperature $\left(T_{\text {gas }}\right)$ were used to derive the first-order global kinetic parameters of glycolic acid decomposition, as shown later in the report.

The remaining free glycolic acid after Eq. (4) was oxidatively decomposed by consuming $\mathrm{O}_{2}$ from $\mathrm{N}_{2} \mathrm{O}_{5}$ :

$$
\mathrm{C}_{2} \mathrm{H}_{4} \mathrm{O}_{3}+\frac{3}{2} \mathrm{O}_{2} \rightarrow 2 \mathrm{CO}_{2}+2 \mathrm{H}_{2} \mathrm{O}
$$

\subsubsection{New Global Kinetic Parameters of $\mathrm{H}_{2}$ Combustion}

A new set of global kinetic parameters for the $\mathrm{H}_{2}$ combustion was developed by lumping together all the $\mathrm{H}_{2}$ inputs not only from the cold cap reactions, including the antifoam decomposition, but from Eq. (4). To do so, the fractional conversion of $\mathrm{H}_{2}$ to $\mathrm{H}_{2} \mathrm{O}$ was calculated by targeting $125 \%$ of the measured $\mathrm{H}_{2}$ data in the off-gas at each temperature of each steady state run, as was done for Eq. (4). 
As part of the scope for developing a new model, it was aimed to reduce the conservatism in the antifoam decomposition scheme used in the current model based on the results of the Phase 2 test as well as the crucible study using feeds spiked with excess antifoam. As shown in Table 2-10 and Figure 2-2, however, there was little or no difference in the $\mathrm{H}_{2}$ evolution between the baseline and spiked feeds because the excess nitrate in the NGA flowsheet feeds were able to oxidize the additional antifoam carbon added; in the presence of excess nitrate, the antifoam spike used was not large enough to show its impact on the off-gas data. This was part of the reason for taking the current approach of developing new global kinetic parameters for $\mathrm{H}_{2}$ combustion.

\subsection{Mass and Energy Balance Calculations}

Since only the steady state conditions were considered in this study, it was not necessary to run the system dynamics portion of the MOG dynamics model. Instead, a spreadsheet was developed that calculates the steady state component mass and energy balances from the melter to the offgas condensate tank (OGCT). The output of the cold cap model was input into this spreadsheet, which was used to estimate both air inleakage and actual gas temperature iteratively and further calculate the global kinetics of $\mathrm{H}_{2}$ and $\mathrm{CO}$ combustion in the CEF vapor space. The steps that were followed to determine the new melter off-gas flammability model parameters for the NGA flowsheet included:

1. Assume a value for the fractional nitrate removal.

2. Develop input vector for the 4-stage cold cap model.

3. Run 4-stage cold cap model.

4. Develop input vector for the spreadsheet using cold cap model output.

5. Perform steady state component mass and energy balance calculations at the lowest VS temperature run during each steady state series of Phase 2.

6. Check if calculated $\mathrm{H}_{2}$ and $\mathrm{CO}$ match measured data closely. If not, go Step 1 and repeat

7. Develop input vector for the 4-stage cold cap model at the last fractional nitrate removal.

8. Run 4-stage cold cap model.

9. Develop the input vector for the spreadsheet using the output of the cold cap model.

10. Perform steady state component mass and energy balance calculations at each VS temperature of a given steady state run of Phase 2 to determine:

a. Fractional conversion of Eq. (4) by targeting calculated $\mathrm{CO}$ at $125 \%$ of measured data.

b. Fractional conversion of $\mathrm{H}_{2}$ combustion by targeting calculated $\mathrm{H}_{2}$ at $125 \%$ of measured data.

11. Determine first-order global kinetic parameters of Eq. (4) and $\mathrm{H}_{2}$ combustion for each feed under bubbled and non-bubbled conditions.

12. Obtain steady state data just prior to the 13 " $\mathrm{H}_{2} \mathrm{O}$ pressure spike and repeat Steps $7-10$.

13. Obtain bounding Phase 2 data, including VS temperature and $\mathrm{CO}_{2}$, during the $13 " \mathrm{H}_{2} \mathrm{O}$ pressure spike.

14. Perform steady state component mass and energy balance calculations using bounding data and determine the magnitudes of both condensable and non-condensable surges by matching calculated film cooler $\triangle \mathrm{P}$ and $\mathrm{CO}_{2}$ with their respective measured data.

15. Perform further analysis of the Phase 2 data in light of model results. 


\subsection{Cold Cap Model Run}

\subsubsection{Model Input}

The $100 \%$ and $125 \%$ acid stoichiometry SRAT product compositions in Table 2-6 and Table 2-7, respectively, were remediated per Table 2-8 and the free acid fractions adjusted according to Figure 2-1. The resulting Phase 2 compositions were then converted into the cold cap model input vectors as shown in Table 4-1 and Table 4-2 for 100\% and 125\% acid stoichiometry, respectively. Note that these input compositions were developed based on the final nitrate removal fractions of $22 \%$ and $29 \%$ for the $100 \%$ and $125 \%$ acid stoichiometry, respectively, as determined in Steps 17 above; the higher removal fraction for the $125 \%$ acid stoichiometry feed was expected since its nitrate level was $15 \%$ higher than that of the $100 \%$ acid stoichiometry feed. Some trace level species such as $\mathrm{Ba}, \mathrm{Cr}$ and $\mathrm{Ti}$ were left out of these input vectors; yet the input still accounted for over $99.6 \%$ of the dried feeds.

Table 4-1. 4-Stage Cold Cap Model Input at $228 \mathrm{lb} / \mathrm{hr}$ Glass Rate (100\% Acid).

\begin{tabular}{|c|c|c|c|}
\hline Species & $\begin{array}{r}\text { Stage } 1 \\
\text { (gmole/hr) }\end{array}$ & $\begin{array}{r}\text { Stage } 2 \\
\text { (gmole/hr) }\end{array}$ & $\begin{array}{r}\text { Stage } 3 \\
\text { (gmole/hr) }\end{array}$ \\
\hline \multicolumn{4}{|l|}{ Condensed } \\
\hline $\mathrm{Al}_{2} \mathrm{O}_{3}$ & 0 & 95.3261 & 0 \\
\hline $\mathrm{B}_{2} \mathrm{O}_{3}$ & 75.9177 & 0 & 0 \\
\hline $\mathrm{CaO}$ & 0 & 10.7410 & 0 \\
\hline $\mathrm{CuO}$ & 0.7554 & 0 & 0 \\
\hline $\mathrm{Fe}_{2} \mathrm{O}_{3}$ & 73.1092 & 0 & 0 \\
\hline $\mathrm{K}_{2} \mathrm{O}$ & 1.5389 & 0 & 0 \\
\hline $\mathrm{Li}_{2} \mathrm{O}$ & 0 & 176.8793 & 0 \\
\hline $\mathrm{MgO}$ & 0 & 0 & 13.5204 \\
\hline $\mathrm{MnO}_{2}$ & 0 & 5.7202 & 0 \\
\hline $\mathrm{MnO}$ & 42.1785 & 0 & 0 \\
\hline $\mathrm{Na}_{2} \mathrm{O}$ & 110.0426 & 92.2291 & 0 \\
\hline $\mathrm{NiO}$ & 19.3854 & 0 & 0 \\
\hline $\mathrm{SiO}_{2}$ & 859.1340 & 0 & 0 \\
\hline $\mathrm{CaSO}_{4}$ & 0 & 0 & 0 \\
\hline $\mathrm{Na}_{2} \mathrm{SO}_{4}$ & 0 & 0 & 3.9226 \\
\hline \multicolumn{4}{|l|}{ Volatiles } \\
\hline $\mathrm{H}_{2} \mathrm{O}$ & 535.8023 & 4.7415 & 1.8966 \\
\hline $\mathrm{CO}$ & 77.5493 & 84.8672 & 32.2559 \\
\hline $\mathrm{CO}_{2}$ & 21.4766 & 31.1073 & 10.7520 \\
\hline $\mathrm{H}_{2}$ & 65.7019 & 80.6398 & 32.2559 \\
\hline $\mathrm{O}_{2}$ & 22.7403 & 55.6328 & 22.2531 \\
\hline $\mathrm{NO}$ & 33.3797 & 55.6328 & 22.2531 \\
\hline $\mathrm{NO}_{2}$ & 33.3797 & 55.6328 & 22.2531 \\
\hline \multicolumn{4}{|c|}{ Direct Feed to VS } \\
\hline $\mathrm{HCOOH}$ & \multicolumn{3}{|c|}{1.0121} \\
\hline $\mathrm{C}_{2} \mathrm{H}_{4} \mathrm{O}_{3}$ & \multicolumn{3}{|c|}{30.8468} \\
\hline $\mathrm{HNO}_{3}$ & \multicolumn{3}{|c|}{5.3493} \\
\hline $\mathrm{CH}_{4}$ & \multicolumn{3}{|c|}{13.1774} \\
\hline $\mathrm{N}_{2} \mathrm{O}_{5}$ & \multicolumn{3}{|c|}{27.5054} \\
\hline $\mathrm{H}_{2} \mathrm{O}$ (free) & \multicolumn{3}{|c|}{$8,949.2894$} \\
\hline
\end{tabular}


Table 4-2. 4-Stage Cold Cap Model Input at $228 \mathrm{lb} / \mathrm{hr}$ Glass Rate (125\% Acid).

\begin{tabular}{|c|c|c|c|}
\hline Species & $\begin{array}{r}\text { Stage } 1 \\
\text { (gmole/hr) }\end{array}$ & $\begin{array}{r}\text { Stage } 2 \\
\text { (gmole/hr) }\end{array}$ & $\begin{array}{r}\text { Stage } 3 \\
\text { (gmole/hr) }\end{array}$ \\
\hline \multicolumn{4}{|l|}{ Condensed } \\
\hline $\mathrm{Al}_{2} \mathrm{O}_{3}$ & 0 & 95.7092 & 0 \\
\hline $\mathrm{B}_{2} \mathrm{O}_{3}$ & 75.8205 & 0 & 0 \\
\hline $\mathrm{CaO}$ & 0 & 11.3877 & 0 \\
\hline $\mathrm{CuO}$ & 0.6840 & 0 & 0 \\
\hline $\mathrm{Fe}_{2} \mathrm{O}_{3}$ & 68.0003 & 0 & 0 \\
\hline $\mathrm{K}_{2} \mathrm{O}$ & 1.3932 & 0 & 0 \\
\hline $\mathrm{Li}_{2} \mathrm{O}$ & 0 & 176.6530 & 0 \\
\hline $\mathrm{MgO}$ & 0 & 0 & 12.7929 \\
\hline $\mathrm{MnO}_{2}$ & 0 & 7.9675 & 0 \\
\hline $\mathrm{MnO}$ & 37.9823 & 0 & 0 \\
\hline $\mathrm{Na}_{2} \mathrm{O}$ & 115.6439 & 91.9386 & 0 \\
\hline $\mathrm{NiO}$ & 18.3369 & 0 & 0 \\
\hline $\mathrm{SiO}_{2}$ & 858.4684 & 0 & 0 \\
\hline $\mathrm{CaSO}_{4}$ & 0 & 0 & 0 \\
\hline $\mathrm{Na}_{2} \mathrm{SO}_{4}$ & 0 & 0 & 3.6122 \\
\hline \multicolumn{4}{|l|}{ Volatiles } \\
\hline $\mathrm{H}_{2} \mathrm{O}$ & 512.3434 & 12.5036 & 5.0014 \\
\hline $\mathrm{CO}$ & 83.1534 & 102.4398 & 39.3303 \\
\hline $\mathrm{CO}_{2}$ & 16.6692 & 28.5536 & 9.7758 \\
\hline $\mathrm{H}_{2}$ & 64.6317 & 85.8222 & 34.3289 \\
\hline $\mathrm{O}_{2}$ & 24.9458 & 58.0695 & 23.2278 \\
\hline $\mathrm{NO}$ & 34.8417 & 58.0695 & 23.2278 \\
\hline $\mathrm{NO}_{2}$ & 34.8417 & 58.0695 & 23.2278 \\
\hline \multicolumn{4}{|c|}{ Direct Feed to VS } \\
\hline $\mathrm{HCOOH}$ & \multicolumn{3}{|c|}{0.9987} \\
\hline $\mathrm{C}_{2} \mathrm{H}_{4} \mathrm{O}_{3}$ & \multicolumn{3}{|c|}{50.3538} \\
\hline $\mathrm{HNO}_{3}$ & \multicolumn{3}{|c|}{0.0000} \\
\hline $\mathrm{CH}_{4}$ & \multicolumn{3}{|c|}{12.2565} \\
\hline $\mathrm{N}_{2} \mathrm{O}_{5}$ & \multicolumn{3}{|c|}{51.0631} \\
\hline $\mathrm{H}_{2} \mathrm{O}$ (free) & \multicolumn{3}{|c|}{$8,888.2199$} \\
\hline
\end{tabular}

\subsubsection{Model Output}

The calculated compositions (or flow rates) of glass and calcine gases for the $100 \%$ and $125 \%$ acid stoichiometry feeds are shown in Table 4-3. It is seen that the predicted glass compositions are split in groups or phases; the letter 1 after each species in the melt phase denotes "liquid." These liquid or melt species do not necessarily represent independent molecular or ionic species but serve to represent the local associative order. ${ }^{20}$ Due to structural similarities, spinels readily form solid solutions with one another and thus are allowed to form a separate phase of their own. Each of the species in the Invariant Condensed Phase (ICP) is assumed to form a separate phase by itself. The calculated redox of the two Phase 2 feeds was $0.11-0.12$, which lie between the measured values of $\sim 0.25$ in a closed crucible and those of the glass samples pulled from the CEF which were fully oxidized. 
Table 4-3. 4-Stage Cold Cap Model Output at $228 \mathrm{lb} / \mathrm{hr}$ Glass Rate.

\begin{tabular}{|c|c|c|}
\hline Species & $\begin{array}{r}100 \% \text { Acid } \\
\text { (gmole/hr) }\end{array}$ & $\begin{array}{r}125 \% \text { Acid } \\
\text { (gmole/hr) }\end{array}$ \\
\hline \multicolumn{3}{|l|}{ Melt } \\
\hline $\mathrm{SiO}_{2} 1$ & 636.3560 & 631.3010 \\
\hline $\mathrm{Na}_{2} \mathrm{SiO}_{3}$ & 206.1730 & 211.1620 \\
\hline $\mathrm{LiBO}_{2} 1$ & 151.1770 & 150.9880 \\
\hline $\mathrm{LiAlO}_{2} 1$ & 190.7000 & 191.4000 \\
\hline $\mathrm{Fe}_{3} \mathrm{O}_{4} 1$ & 12.8558 & 12.8492 \\
\hline $\mathrm{MgSiO}_{3} 1$ & 13.1324 & 12.3746 \\
\hline $\mathrm{FeO} 1$ & 2.7679 & 2.7665 \\
\hline $\mathrm{CaFe}_{2} \mathrm{O}_{4}$ & 3.0431 & 3.3007 \\
\hline $\mathrm{B}_{2} \mathrm{O}_{3} \mathrm{l}$ & 0.0004 & 0.0005 \\
\hline $\mathrm{Ca}_{2} \mathrm{SiO}_{4}$ & 1.6552 & 1.9330 \\
\hline $\mathrm{Ca}_{3} \mathrm{MgSi}_{2} \mathrm{O}_{8}$ & 0.2244 & 0.2680 \\
\hline $\mathrm{Fe}_{2} \mathrm{SiO}_{4}$ & 0.1067 & 0.1058 \\
\hline $\mathrm{Li}_{2} \mathrm{O} 1$ & 5.9617 & 5.5061 \\
\hline $\mathrm{K}_{2} \mathrm{SiO}_{3}$ & 1.2279 & 1.0876 \\
\hline $\mathrm{KBO}_{2}$ & 0.6221 & 0.6108 \\
\hline \multicolumn{3}{|l|}{ Spinel } \\
\hline $\mathrm{NiFe}_{2} \mathrm{O}_{4}$ & 19.3900 & 18.3400 \\
\hline $\mathrm{Mn}_{3} \mathrm{O}_{4}$ & 15.9667 & 15.3157 \\
\hline $\mathrm{CuFe}_{2} \mathrm{O}_{4}$ & 0.7550 & 0.6840 \\
\hline $\mathrm{MgFe}_{2} \mathrm{O}_{4}$ & 0.1632 & 0.1474 \\
\hline \multicolumn{3}{|l|}{ ICP } \\
\hline $\mathrm{Fe}_{2} \mathrm{O}_{3}$ & 28.9745 & 24.7651 \\
\hline $\mathrm{CaSO}_{4}$ & 3.7134 & 3.4194 \\
\hline \multicolumn{3}{|l|}{ Calcine Gases } \\
\hline $\mathrm{H}_{2} \mathrm{O}$ & 743.5290 & 728.4460 \\
\hline $\mathrm{CO}_{2}$ & 270.3010 & 289.5720 \\
\hline $\mathrm{H}_{2}$ & 4.0261 & 10.6838 \\
\hline $\mathrm{CO}$ & 0.9091 & 2.6379 \\
\hline $\mathrm{SO}_{2}$ & 0.2094 & 0.1926 \\
\hline $\mathrm{NO}$ & 0.0006 & 0.0004 \\
\hline $\mathrm{N}_{2} \mathrm{O}$ & 111.2850 & 116.1200 \\
\hline $\mathrm{H}_{2} /\left(\mathrm{CO}_{2}+\mathrm{CO}\right)$ & 0.0148 & 0.0366 \\
\hline $\mathrm{CO} / \mathrm{CO}_{2}$ & 0.0034 & 0.0091 \\
\hline \multicolumn{3}{|l|}{ Redox } \\
\hline $\mathrm{Fe}^{+2} / \mathrm{Fe}^{\text {total }}$ & 0.11 & 0.12 \\
\hline Measured (closed crucible) & 0.25 & 0.25 \\
\hline
\end{tabular}




\subsection{Mass and Energy Balance Calculations}

A spreadsheet was used to perform the component mass and energy balance calculations from the CEF vapor space to the OGCT for each of the 21 steady state data sets. This section describes the input and output of the spreadsheet along with further interpretation of data in light of calculated results. The main goal was to determine the fractional conversions of Eq. (4) and combustion of $\mathrm{H}_{2}$ combustion and further extract first-order global kinetic parameters for those reactions.

\subsubsection{Spreadsheet Input}

The input for the spreadsheet calculations included all the steady state pressure, temperature, and flow data taken during Phase 2, as tabulated in Appendix, as well as the instantaneous flow rates of calcine gases calculated by the cold cap model (Table 4-3) and the direct-input-to-VS volatiles (Table 4-1 and Table 4-2). In order to simulate actual steady state operations, the flow rates of these calcine gas and volatile flows were adjusted down by the Phase 2-to-DWPF feed rate ratio.

\subsubsection{Bases and Assumptions}

Except for $\mathrm{CH}_{4}$ which was detected mostly at $<10 \mathrm{ppm}$, the only other flammable gases identified during Phase 2 were $\mathrm{H}_{2}$ and $\mathrm{CO}$ so the off-gas flammability assessment is made based on $\mathrm{H}_{2}$ and $\mathrm{CO}$ only. Before performing such assessments, however, two unknowns that cannot be measured experimentally and yet have a direct impact on the measured concentrations of $\mathrm{H}_{2}$ and $\mathrm{CO}$ must be estimated from the data collected. The first unknown is the rate of air inleakage into the CEF vapor space which, depending on the CEF vacuum, can constitute a major portion of the total air available for both combustion and dilution. The second is the actual gas temperature in the CEF vapor space $\left(T_{\text {gas }}\right)$ at each measured VS temperature, and it is $T_{\text {gas }}$ that is used in the combustion kinetics calculations. Since gases are mostly transparent to infrared radiation, the actual gas temperatures tend to be lower than those measured using thermocouples, and the magnitude of difference between the two temperatures depends on both design and operating variables such as melter cavity design and feed rate. Furthermore, these two unknowns are interdependent so they must be solved iteratively. Two key assumptions were made in order to facilitate the evaluation of these unknowns by performing mass and energy balance calculations around the film cooler.

\subsubsection{Well-Mixed Reactor}

The CEF vapor space is assumed to be a well-mixed reactor. This assumption is valid since the CEF has 3 fixed air injection points plus a substantial rate of air inleakage. Likewise, the DWPF melter maintains a dedicated air purge through the backup film cooler which was shown to form an air jet extending down to the cold cap, providing good mixing by entrainment. ${ }^{5}$ This assumption enabled the use of $T_{\text {gas }}$ as the representative gas temperature for the entire vapor space.

\subsubsection{First-Order Global Kinetics}

The combustion of $\mathrm{H}_{2}$ and $\mathrm{CO}$ in the vapor space is currently modeled using the first-order global kinetics approach: ${ }^{18}$

$$
-r=k_{o} \exp \left(-E_{a} / R T\right) C
$$

where $-r$ is the reaction rate in $1 \mathrm{bmole} / \mathrm{ft}^{3} / \mathrm{sec}, k_{o}$ the pre-exponential factor in $1 / \mathrm{sec}, E_{a}$ the activation energy in Btu/lbmole, $R$ the gas constant, $T$ the gas temperature in $\mathrm{K}$, and $C$ the concentration of $\mathrm{CO}$ or $\mathrm{H}_{2}$ in lbmole $/ \mathrm{ft}^{3}$. The global first-order kinetic parameters of $\mathrm{CO}$ and $\mathrm{H}_{2}$ oxidation used by the current model are shown in Table 4-4; they were derived from the SGM-9 data and have been in use beginning with the original model. It is the intent of this work to revise the parameters for $\mathrm{H}_{2}$ and continue to use those for $\mathrm{CO}$. The lower temperature bound for these kinetic parameters were extended considerably from $T_{\text {gas }}=393{ }^{\circ} \mathrm{C}$ of the SGM-9 data to $204{ }^{\circ} \mathrm{C} .{ }^{18}$ 
SRNL-STI-2014-00355

Revision 0

Table 4-4. First-Order Global Kinetic Parameters for Vapor Space Combustion. ${ }^{18}$

\begin{tabular}{|c|c|c|c|}
\hline & $\begin{array}{c}\mathrm{k}_{\mathrm{o}} \\
(1 / \mathrm{sec})\end{array}$ & $\begin{array}{c}\mathrm{E}_{\mathrm{a}} \\
(\mathrm{Btu} / \mathrm{lbmole})\end{array}$ & $\mathrm{R}^{2}$ \\
\hline $\mathrm{CO}$ & 1,759 & 22,192 & 0.845 \\
\hline $\mathrm{H}_{2}$ & $2.795 \mathrm{E} 7$ & 38,940 & 0.999 \\
\hline
\end{tabular}

\subsubsection{Spreadsheet Calculations}

The air inleakage and true gas temperature in the CEF vapor space were calculated iteratively by matching; (1) calculated off-gas flow at the film cooler exit with the quencher suction and (2) calculated off-gas temperature at the film cooler exit with the measured data (T15). Specifically, the calculations proceeded in the following order:

1) Off-Gas Header $\Delta P$ - In order to calculate the quencher suction, the $\Delta \mathrm{P}$ across the off-gas header between the quencher inlet and where the film cooler exit pressure is measured was first calculated using: ${ }^{21}$

$$
\Delta P=0.000000280 K W^{\wedge} 2 /\left(D^{\wedge} 4 \rho\right)(27.7073)
$$

where $\Delta \mathrm{P}$ is in " $\mathrm{H}_{2} \mathrm{O}, \mathrm{W}$ the off-gas flow rate in $\mathrm{lb} / \mathrm{hr}, \mathrm{D}$ the inside diameter of the off-gas header in $\mathrm{ft}, \rho$ the off-gas density in $\mathrm{lb} / \mathrm{ft}^{3}$, and $K$ the resistance coefficient calculated as:

$$
K=\left(12 n_{90}+50 n_{R B}+L / D\right) f_{T}+0.5804
$$

where $n_{90}$ is the number of $90^{\circ}$ elbows, $n_{R B}$ the number of return bends, L the total length of straight pipe in $\mathrm{ft}$, and $f_{T}$ the friction factor for turbulent pipe flow. The nominal 2" off-gas header has no $90^{\circ}$ elbow, one return bend, and one $45^{\circ}$ bend with expansion. The extent of iterative calculations involved can be seen from Eq. (7), which shows that the off-gas header $\triangle \mathrm{P}$ depends on not only the off-gas flow rate, which includes one of the unknowns, CEF air inleakage, but the density which depends on the off-gas composition and temperature. And the off-gas temperature in turn depends directly on the temperature of the off-gas exiting the melter, which is the other unknown, the true vapor space gas temperature.

2) Quencher Suction - Once the off-gas header $\Delta \mathrm{P}$ was calculated, it was subtracted from the measured film cooler exit pressure (P3) to calculate the quencher inlet pressure and finally the quencher draft by subtracting the quencher inlet pressure from the measured OGCT outlet pressure. The quencher draft was then used to determine the suction from the vendorprovided performance curve of the 3" scrubber model FIG. 7007 by Schutte \& Keorting. ${ }^{22}$ Since the suction capacity estimated from the performance curve is for air at $20^{\circ} \mathrm{C}$, the actual suction was calculated by taking into account the density difference between air and the CEF off-gas:

$$
Q=Q_{\text {air }} \sqrt{\rho_{\text {air }} / \rho}
$$

where $\mathrm{Q}$ is the suction capacity in acfm, and $\rho$ the density in $\mathrm{lb} / \mathrm{ft}^{3}$.

3) Estimation of Unknowns - The CEF air inleakage rate was varied along with the true vapor space gas temperature, until the calculated off-gas flow and temperature at the film cooler exit matched the quencher suction $(Q)$ and the measured temperature (T15) simultaneously. It 
is noted that after each iteration cycle the vapor space combustion kinetic parameters and all the other relevant component and stream properties such as heat capacities of the CEF off-gas and downstream flows are updated before the next iteration cycle begins.

4) Fractional Conversion of Glycolate Decomposition - Once unknowns were estimated, the fractional conversion of Eq. (4) was varied until calculated CO concentration in the dry offgas using the existing global kinetics of CO combustion matched $125 \%$ of measured data by FTIR.

5) Fractional Conversion of $\mathrm{H}_{2}$ Combustion - The current global kinetic parameters for $\mathrm{H}_{2}$ combustion were overridden with its fractional conversion, which was varied until calculated $\mathrm{H}_{2}$ concentration in the dry off-gas matched $125 \%$ of measured data by MS.

\subsubsection{Spreadsheet Output}

The results of mass and energy balance calculations for the 21 steady state runs are given in Table 4-5; they are presented in the order each steady state case was run from the earliest to latest. Some of the key results are discussed next.

Table 4-5. Output of CEF Phase 2 Off-Gas Calculations.

\begin{tabular}{|c|c|c|c|c|c|c|c|c|}
\hline SS Run & $\begin{array}{l}\text { VS T } \\
\left({ }^{\circ} \mathrm{C}\right)\end{array}$ & $\begin{array}{l}\mathrm{T}_{\text {gas }} \\
\left({ }^{\circ} \mathrm{C}\right)\end{array}$ & $\begin{array}{c}\Delta \mathrm{T} \\
\left({ }^{\circ} \mathrm{C}\right)\end{array}$ & $\begin{array}{l}\text { CEF P } \\
\left(" \mathrm{H}_{2} \mathrm{O}\right)\end{array}$ & $\begin{array}{c}\text { Air } \\
\text { Inleakage } \\
(\mathrm{scfm})\end{array}$ & $\begin{array}{c}\text { Frac } \\
\text { Conv } \\
\text { Eq. (4) }\end{array}$ & $\begin{array}{c}\text { Frac } \\
\text { Conv } \\
\mathrm{H}_{2} \\
\end{array}$ & $\begin{array}{c}\text { Carbon } \\
\text { Balance } \\
\text { (calc-meas) }\end{array}$ \\
\hline \multicolumn{9}{|c|}{ 125\%_B_1X } \\
\hline & 705 & 552 & 153 & -5.22 & 8.85 & 0.5761 & 0.9411 & $-19.7 \%$ \\
\hline & 625 & 460 & 164 & -5.35 & 10.33 & 0.3779 & 0.7878 & $-21.9 \%$ \\
\hline & 481 & 348 & 133 & -4.90 & 10.82 & 0.0461 & 0.3879 & $-8.4 \%$ \\
\hline & 415 & 307 & 108 & -4.74 & 10.34 & 0.0277 & 0.4687 & $0.1 \%$ \\
\hline & 360 & 275 & 85 & -3.48 & 6.71 & 0.0413 & 0.5773 & $2.8 \%$ \\
\hline & 270 & 220 & 50 & -1.16 & 3.48 & 0.0534 & 0.4029 & $-8.0 \%$ \\
\hline \multicolumn{9}{|c|}{ 125\%_NB_1X } \\
\hline & 709 & 513 & 195 & -5.47 & 10.93 & 0.5953 & 0.9626 & $-26.3 \%$ \\
\hline & 393 & 284 & 109 & -5.46 & 14.77 & 0.0423 & 0.1629 & $-26.1 \%$ \\
\hline & 351 & 262 & 89 & -5.04 & 13.86 & 0.0414 & 0.2822 & $-27.6 \%$ \\
\hline & 302 & 232 & 69 & -4.96 & 11.86 & 0.0245 & 0.1414 & $-23.7 \%$ \\
\hline \multicolumn{9}{|c|}{$100 \%$ NB_1X } \\
\hline & 697 & 507 & 190 & -5.27 & 11.39 & 0.7324 & 0.9424 & $-22.3 \%$ \\
\hline & 600 & 424 & 176 & -5.70 & 12.40 & 0.4163 & 0.7991 & $-19.1 \%$ \\
\hline & 496 & 337 & 159 & -6.00 & 13.66 & 0.0863 & 0.4664 & $-17.4 \%$ \\
\hline & 410 & 290 & 119 & -5.46 & 14.02 & 0.0368 & 0.4608 & $-18.3 \%$ \\
\hline & 344 & 256 & 88 & -4.46 & 12.86 & 0.0262 & 0.2792 & $-16.1 \%$ \\
\hline & 326 & 250 & 76 & -4.02 & 11.23 & 0.0329 & 0.2473 & $-23.5 \%$ \\
\hline \multicolumn{9}{|c|}{ 100\%_B_1X } \\
\hline & 705 & 529 & 176 & -4.81 & 11.98 & 0.7985 & 0.9574 & $-25.5 \%$ \\
\hline & 592 & 424 & 168 & -4.66 & 12.84 & 0.3383 & 0.7463 & $-18.6 \%$ \\
\hline & 471 & 326 & 145 & -4.42 & 15.16 & 0.1513 & 0.4447 & $-23.2 \%$ \\
\hline & 373 & 276 & 97 & -5.06 & 14.56 & 0.0788 & 0.2261 & $-14.4 \%$ \\
\hline & 323 & 243 & 80 & -1.13 & 6.10 & 0.0832 & 0.3520 & $-8.5 \%$ \\
\hline
\end{tabular}




\subsubsection{CEF Air Inleakage}

It appears that the calculated air inleakage rates increased gradually with time, indicating that the system became less tight as the Phase 2 test progressed. For example, the calculated air inleakage rate during the $100 \%$ B_1X run at $323{ }^{\circ} \mathrm{C}$ was nearly twice that of the $125 \%$ B_ $1 \mathrm{X}$ at $270{ }^{\circ} \mathrm{C}$ despite the fact that the CEF pressure was the same at -1.1 " $\mathrm{H}_{2} \mathrm{O}$ in both runs. In fact, two of the six 125\%_NB_1X runs that were repeated toward the end of Phase 2 had to be discarded since their calculated air inleakage rates were over $20 \mathrm{scfm}$, which made it difficult to mesh the data into those obtained earlier. Noting that the range of pressure variations during the $125 \%$ B_1X run was comparatively large, the calculated air inleakage rates during that run were plotted in Figure 4-1 as a function of the differential pressure $\triangle \mathrm{P}$ between the $\mathrm{CEF}$ vapor space and the ambient air and a good power-function correlation between the two variables is shown. However, the same correlations for the remaining cases run later were not nearly as good.

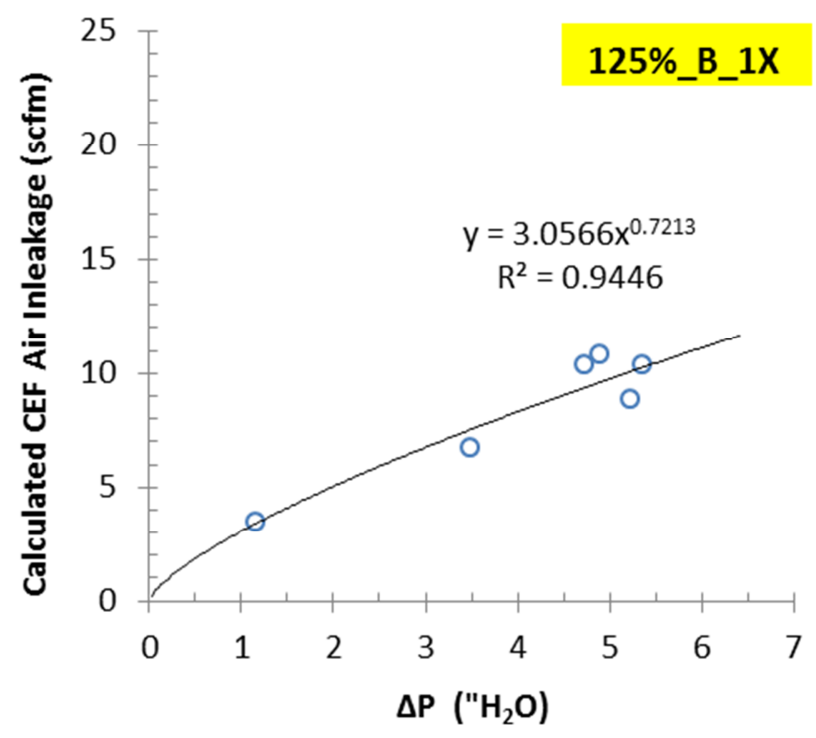

Figure 4-1. Calculated Air Inleakage during 125\%_B_1X Run.

The calculated air inleakage rates for the entire Phase 2 run are compared in Figure 4-2 to those from the earlier CEF runs. The non-existent correlation between the calculated air inleakage rate and $\sqrt{ } \Delta P$ for the Phase 1 run was attributed to the potential air infiltration through the pour tube due to intermittent glass pouring during low VS temperature runs. ${ }^{8}$ The same situation was also encountered in Phase 2 during the non-bubbled runs at low VS temperatures; however, the calculated air inleakage rates appear less scattered. Efforts made to reduce the air inleakage rate from those of the 2010 run appear to have worked; however, the calculated air inleakage rates in excess of $10 \mathrm{scfm}$ at nominal $-5 " \mathrm{H}_{2} \mathrm{O}$ is still large considering that the design basis air inleakage rate of the DWPF melter which has an effective melt surface area 11 times larger than the CEF is only $\sim 20 \mathrm{scfm}$. This is one of the areas that need be improved upon in order to make the scale up of the CEF data more straightforward. 
SRNL-STI-2014-00355

Revision 0

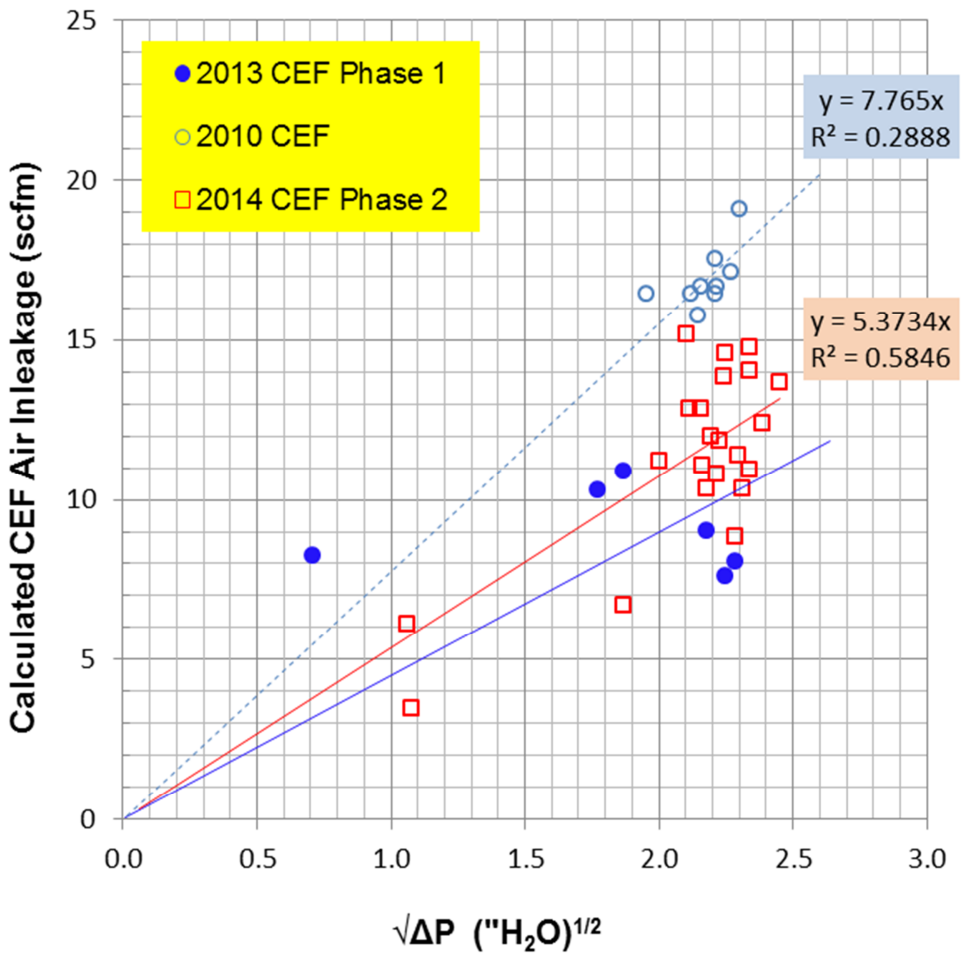

Figure 4-2. Comparison of Air Inleakage Rates among CEF Runs.

\subsubsection{Vapor Space Gas Temperature}

The calculated gas temperatures in the CEF vapor space $\left(\mathrm{T}_{\text {gas }}\right)$ are plotted in Figure 4-3 against the measured VS temperatures during the 100\%_NB_1X run as an example. As expected, the measured temperatures were higher than the calculated gas temperatures due to infrared radiation incident on the thermocouple, while gases are mostly transparent to such radiation. For example, at the measured vapor space temperature of $697^{\circ} \mathrm{C}$, the calculated gas temperature was $507{ }^{\circ} \mathrm{C}$, which agrees well with that calculated from the current DWPF correlation shown in Eq. (10). However, at the measured vapor space temperature of $326^{\circ} \mathrm{C}$, the calculated gas temperature was $250{ }^{\circ} \mathrm{C}$ vs. $170{ }^{\circ} \mathrm{C}$ calculated from Eq. (10), which means that the combustion rate based on Eq. (10) would be lower by a factor of 5 than using calculated $\mathrm{T}_{\text {gas }}$, Considering that most safety basis calculations are performed at $\mathrm{T}_{\text {gas }}<400{ }^{\circ} \mathrm{C}$, this represents a significant source of conservatism in the current DWPF control strategy to mitigate potential off-gas flammability.

$$
T_{\text {gas }}=0.91685 T_{\text {meas }}-128, T_{\text {meas }} \leq 705^{\circ} \mathrm{C}
$$

The difference between measured VS temperature and $T_{\text {gas }}(\Delta T)$ are plotted in Figure 4-4; the larger the $\Delta \mathrm{T}$, the greater the degree of conservatism in the off-gas flammability assessment. It is shown that Eq. (10) begins to under predict $\mathrm{T}_{\text {gas }}$ beginning at $\sim 600{ }^{\circ} \mathrm{C}$ and the degree of under prediction exponentially increases with decreasing temperature. These results are in accordance with the theory of radiative heat transfer and consistent with the earlier findings from the Phase 1 data analysis. ${ }^{8}$ 


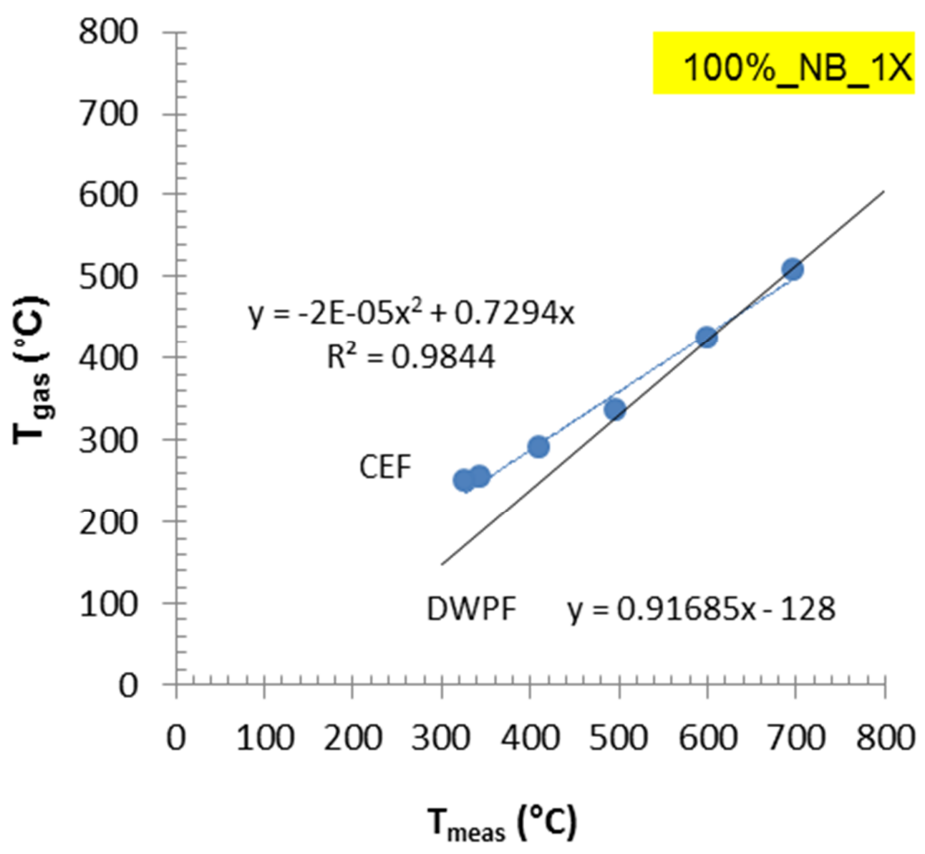

Figure 4-3. Measured vs. Calculated Gas Temperature during 100\%_NB_1X.

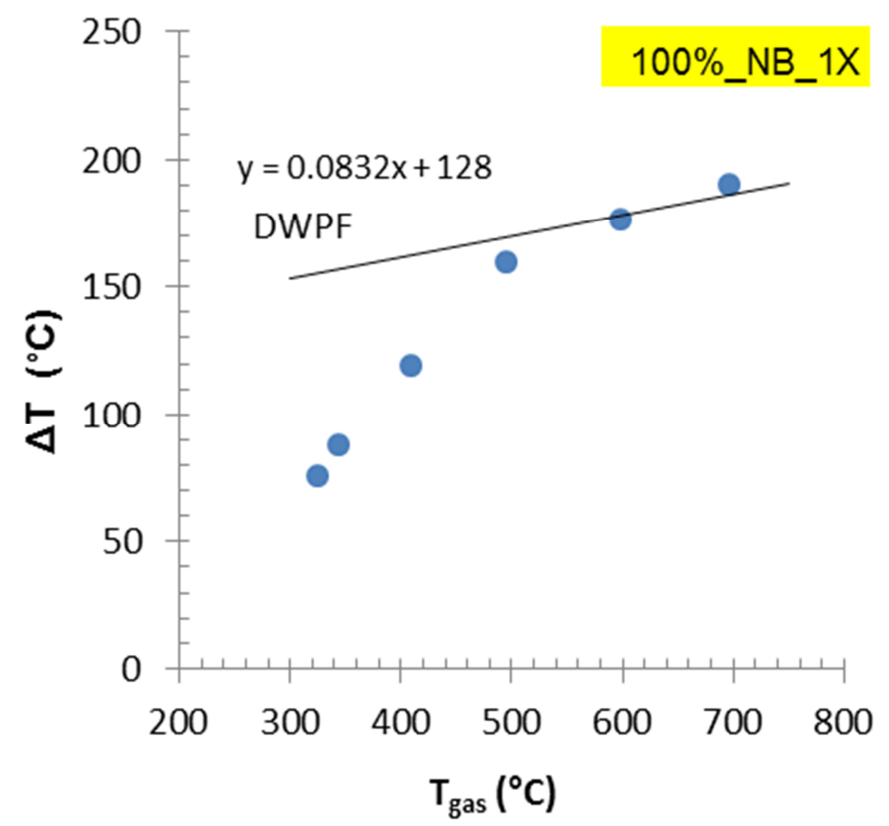

Figure 4-4. $\Delta T$ between $T_{\text {gas }}$ and Measured VS Temperatures. 


\subsubsection{Global Kinetic Parameters of Glycolic Acid Decomposition}

The calculated fractional conversions of glycolic acid decomposition via Eq. (4) are plotted against $\mathrm{T}_{\text {gas }}$ in Figure $4-5$ for the $100 \%$ acid stoichiometry feed as an example. These conversions were calculated by forcing the calculated $\mathrm{CO}$ concentration using the existing $\mathrm{CO}$ oxidation kinetic parameters to match $125 \%$ of measured $\mathrm{CO}$ data. The fact that the calculated conversions of bubbled and non-bubbled runs are relatively close to each other supports the model basis of not including the glycolic acid decomposition as part of the cold cap reactions. Moreover, both conversion profiles look similar to the classical Arrhenius-type reaction rate profiles in the decomposition did not occur to any appreciable extent until $t_{\text {gas }}=\sim 350{ }^{\circ} \mathrm{C}$, above which the rate of decomposition increased rapidly.

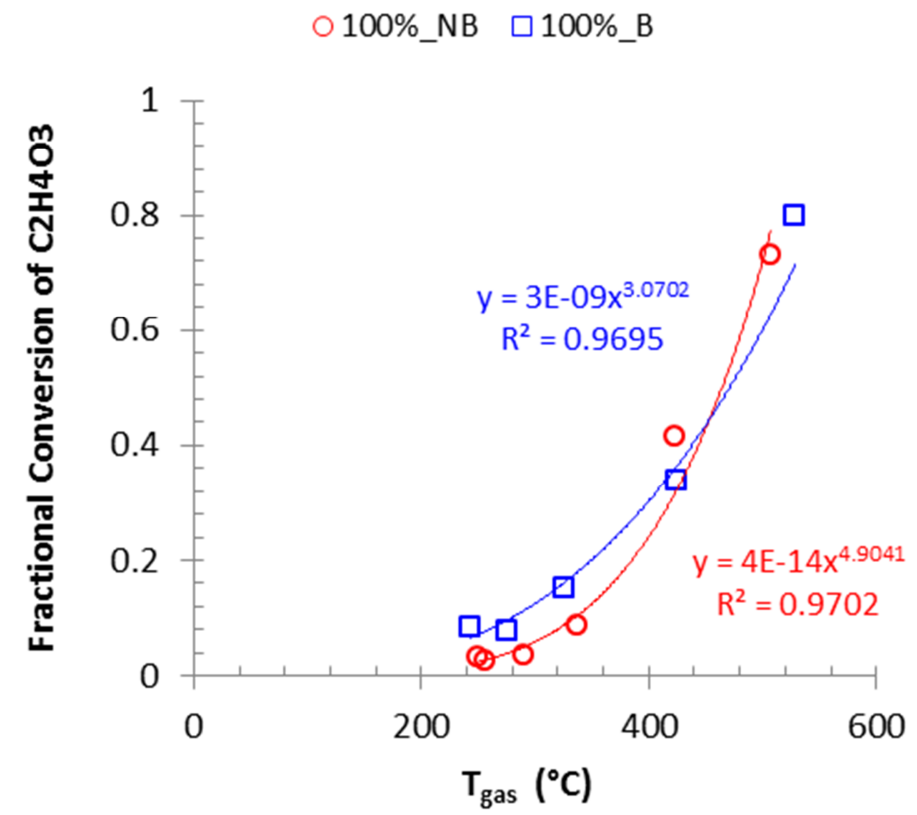

Figure 4-5. Fractional Conversion of $\mathrm{C}_{2} \mathrm{H}_{4} \mathrm{O}_{3}$ Decomposition vs. $\mathrm{T}_{\text {gas }}$

The global kinetic parameters of glycolic acid decomposition were derived next using the firstorder rate constant of Arrhenius type taken from Eq. (6):

$$
k=k_{0} \exp \left(-E_{a} / R T\right)
$$

where the first-order rate constant $k$ is in $1 /$ s. By taking logarithm on both sides of Eq. (11),

$$
\ln k=\ln k_{0}-\left(E_{a} / R\right)(1 / T)
$$

And the first-order rate constant is calculated by integrating Eq. (6): ${ }^{.3}$

$$
k=\frac{F_{i} X}{F_{0} \tau}
$$

where $F_{i}$ and $F_{o}$ are inlet and out flow rates of glycolic acid, respectively, in lbmole $/ \mathrm{hr}, X$ the fractional conversion, and $\tau$ the gas residence time in the vapor space in seconds. By substituting in the values of $F_{i}, F_{o}$ and $\tau$ from the spreadsheet along with the calculated conversion $\mathrm{X}$ from 
Table 4-5 into Eq. (13), $k$ is calculated for a given $T_{\text {gas }}$. By repeating these steps, the values of $\mathrm{k}$ are calculated for all $T_{g a s}$ in each of the four steady state series. The values of $k_{o}$ and $E_{a}$ are then estimated from the slope and y-intercept of the $\ln k$ vs. $1 / T$ plots, as shown in Figure 4-6 for the $100 \%$ B_1X run as an example. The resulting first-order global kinetic parameters of glycolic acid decompositions are tabulated in Table 4-6.

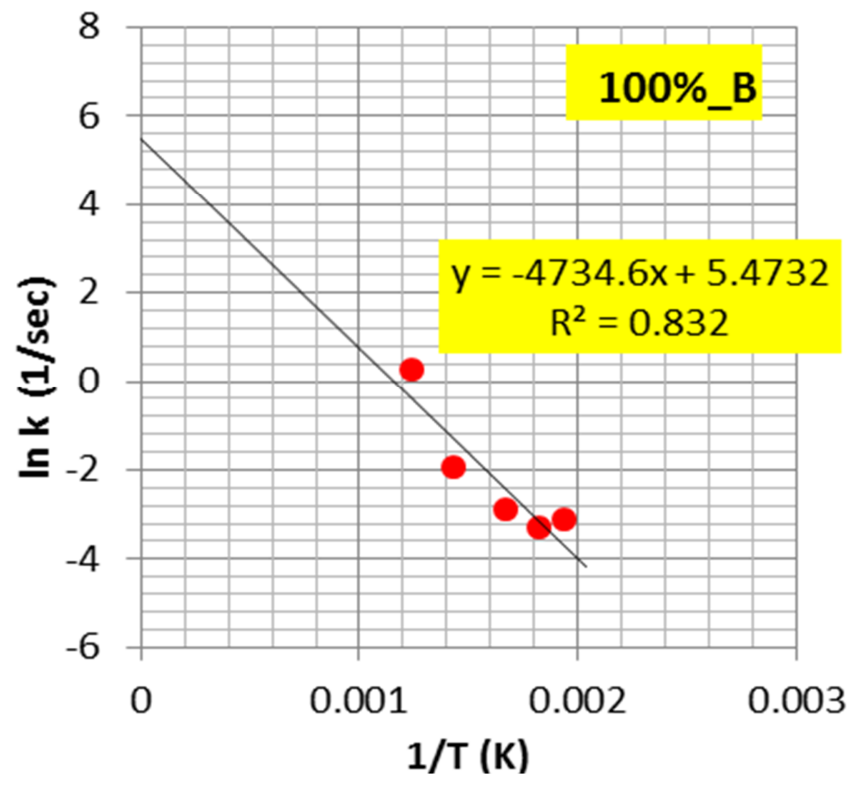

Figure 4-6. Plot of $\ln (k)$ vs. 1/T for Glycolic Acid Decomposition.

Table 4-6. First-Order Global Kinetic Parameters of Glycolic Acid Decomposition.

\begin{tabular}{|l|r|r|r|r|}
\hline & $100 \% \_N B \_1 X$ & $100 \% \_B \_1 X$ & $125 \% \_N B \_1 X$ & $125 \% \_N B \_1 X$ \\
\hline $\mathrm{k}_{0, \mathrm{G}}(1 / \mathrm{sec})$ & $2,246.44$ & 238.22 & 361.37 & 24.36 \\
\hline $\mathrm{E}_{\mathrm{a}, \mathrm{G}}(\mathrm{Kcal} /$ gmole $)$ & 13.05 & 9.40 & 10.76 & 7.70 \\
\hline $\mathrm{E}_{\mathrm{a}, \mathrm{G}}(\mathrm{Btu} /$ lbmole $)$ & 23,486 & 16,924 & 19,375 & 13,854 \\
\hline
\end{tabular}

Using the kinetic parameters given in Table 4-6, the first-order rate constant of glycolic acid decomposition was next calculated as a function of $\mathrm{T}_{\text {gas }}$ using Eq. (11) and the resulting rate constant profiles of the four steady state run series are compared in Figure 4-7. It is shown that either the 100\%_B or 100\%_NB run produced the highest first-order rate constant of the four runs depending on $\mathrm{T}_{\text {gas }}$. However, the first-order rate constant of the $100 \%$ NB becomes the lowest of the four at $\mathrm{T}_{\text {gas }}<\sim 300{ }^{\circ} \mathrm{C}$, while that of the $100 \%$ B B remains the highest at $\mathrm{T}_{\text {gas }}<$ $\sim 550{ }^{\circ} \mathrm{C}$. Since Eq. (4) produces both $\mathrm{H}_{2}$ and $\mathrm{CO}$, it would be conservative from the off-gas flammability control standpoint to use the kinetic parameters derived for the 100\%_B_1X run in the DWPF melter off-gas flammability model. It turns out that use of Eq. (4) was the key to successfully explaining the measured trend of increasing $\mathrm{CO}$ with increasing temperature, which seems counterintuitive from the combustion kinetics point of view but is one of the unique offgas trends seen with the NGA flowsheet feeds but not with the NFA flowsheet feeds. 
SRNL-STI-2014-00355

Revision 0

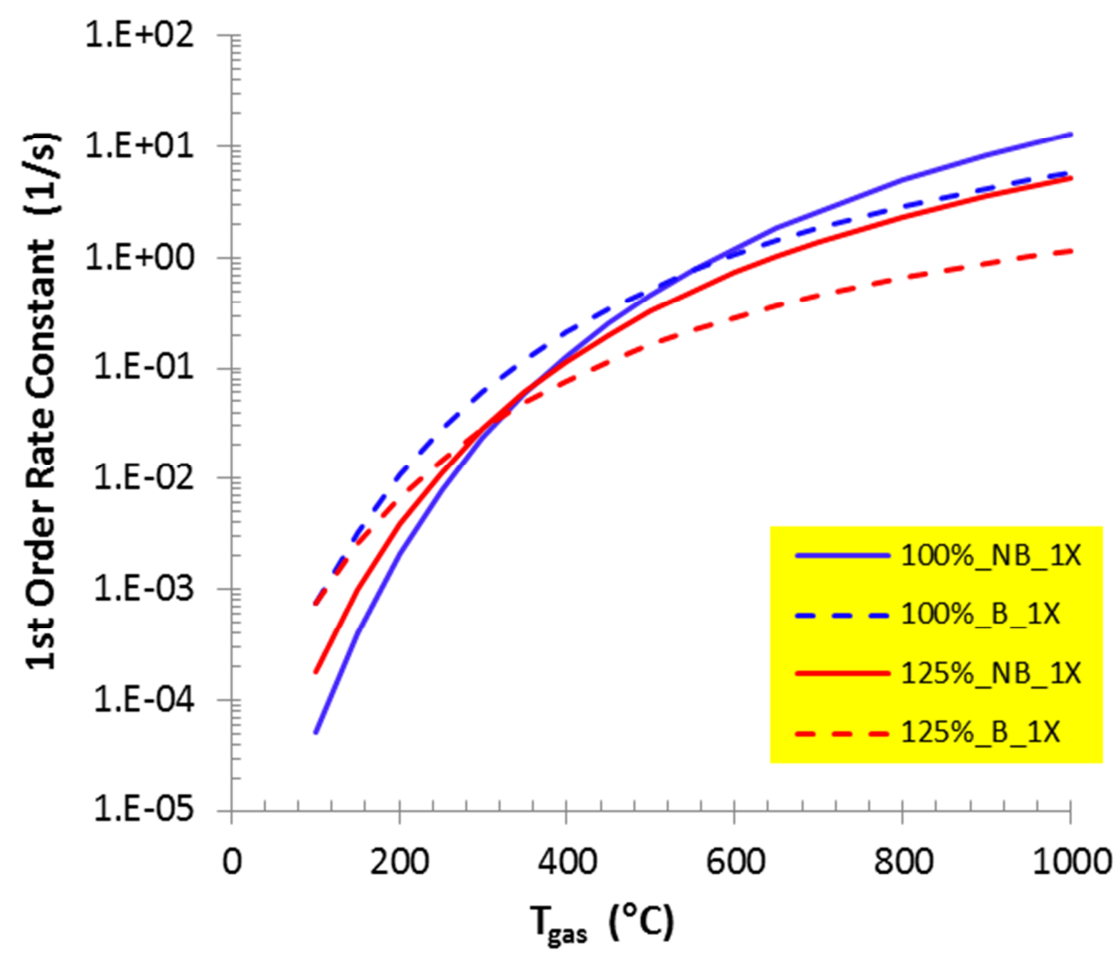

Figure 4-7. Profiles of First-Order Rate Constants of Glycolic Acid Decomposition.

\subsubsection{Global Kinetic Parameters of $\mathrm{H}_{2}$ Combustion}

The process of deriving the global kinetic parameters of $\mathrm{H}_{2}$ combustion is identical to that used for the glycolic acid decomposition. The values of $k_{o}$ and $E_{a}$ were estimated from the slope and yintercept of the $\ln k$ vs. 1/T plot, as shown in Figure 4-8 for the 100\%_NB_1X run as an example:

$$
\begin{aligned}
& k_{o}=\exp (y-\text { intercept })=\exp (7.479)=1,770.47 / \mathrm{sec} \\
& E_{a}=(- \text { slope })(R)=(5,039.8 \mathrm{~K})\left(0.001986 \frac{\mathrm{kcal}}{\text { gmole } \mathrm{K}}\right)=10.008 \mathrm{kcal} / \mathrm{gmole}
\end{aligned}
$$

The resulting first-order global kinetic parameters of $\mathrm{H}_{2}$ combustion are tabulated in Table 4-7 along with those used in the current model. The first-order rate constant for the $\mathrm{H}_{2}$ combustion was next calculated as a function of $\mathrm{T}_{\text {gas }}$ using the new kinetic parameters and the resulting rate constant profiles of the four steady state run series are compared in Figure 4-9 along with that calculated using the current parameters. It is interesting to note that all profiles cross each other at $\mathrm{T}_{\text {gas }}=\sim 370^{\circ} \mathrm{C}$, which means that both new and existing models predict the same global rate of $\mathrm{H}_{2}$ combustion regardless of bubbling and acid stoichiometry tested during Phase 2. Moreover, all new rate constants are lower than the current rate constant at $\mathrm{T}_{\text {gas }}>\sim 370{ }^{\circ} \mathrm{C}$ but higher at $\mathrm{T}_{\text {gas }}<$ $\sim 370{ }^{\circ} \mathrm{C}$. Incidentally, it was at $\mathrm{T}_{\text {gas }}=\sim 370^{\circ} \mathrm{C}$ when the existing model began to over predict the Phase $1 \mathrm{H}_{2}$ data significantly with further decrease in temperature. It was determined that the new global kinetic parameters increase the rate of $\mathrm{H}_{2}$ combustion at $\mathrm{T}_{\text {gas }}<\sim 370{ }^{\circ} \mathrm{C}$, which should help the model better predict the Phase 1 data, resulting in reduced conservatism. At $\mathrm{T}_{\text {gas }}>\sim 370{ }^{\circ} \mathrm{C}$, the new kinetic parameters decrease the rate of $\mathrm{H}_{2}$ combustion; however, at higher temperatures, the reaction rates are already high so the impact of slowing down kinetics is not nearly as large. 


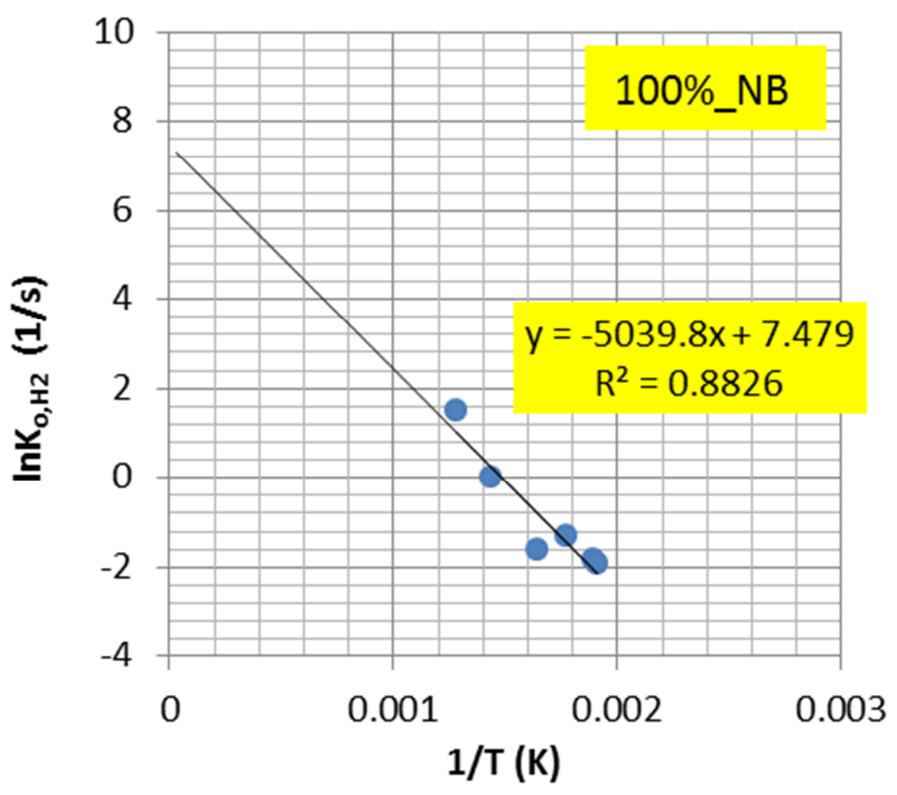

Figure 4-8. Plot of $\ln (k)$ vs. $1 / T$ for $\mathrm{H}_{2}$ Combustion.

Table 4-7. First-Order Global Kinetic Parameters of $\mathrm{H}_{2}$ Combustion @ $1 X$ Antifoam.

\begin{tabular}{|c|r|r|r|r|r|}
\hline & $100 \% \_N B$ & $100 \% \_B$ & $125 \% \_N B$ & $125 \% \_N B$ & Current \\
\hline $\mathrm{k}_{\mathrm{o}, \mathrm{H} 2}(1 / \mathrm{sec})$ & $1,770.47$ & $1,952.37$ & $36,534.05$ & 67.66 & $2.795 \mathrm{E} 7$ \\
\hline $\mathrm{E}_{\mathrm{a}, \mathrm{H} 2}(\mathrm{Kcal} / \mathrm{gmole})$ & 10.01 & 10.02 & 13.65 & 5.64 & 21.63 \\
\hline $\mathrm{E}_{\mathrm{a}, \mathrm{H} 2}(\mathrm{Btu} / \mathrm{lbmole})$ & 18,015 & 18,032 & 24,562 & 10,158 & 38,940 \\
\hline
\end{tabular}

Figure 4-9 also shows that the profiles of the 100\%_B and 100_NB runs lie on top of each other, indicating that the rate constants are independent of bubbling even though the new global kinetics includes the effects of antifoam decomposition in the cold cap. On the other hand, the impact of bubbling on the rate constant is evident in the $125 \%$ acid stoichiometry runs. However, the impact is not uniform for all $\mathrm{T}_{\text {gas }}$; it reverses its direction at $\mathrm{T}_{\text {gas }}=\sim 370{ }^{\circ} \mathrm{C}$. For the purpose of offgas flammability control, the new kinetic parameters derived from the $100 \%$ acid stoichiometry feed data are recommended for their consistency and still providing a sufficient level of increase in rate constant at at $\mathrm{T}_{\text {gas }}<\sim 370{ }^{\circ} \mathrm{C}$, e.g. an order-of-magnitude increase over the current rate constant at $\mathrm{T}_{\text {gas }}=\sim 250{ }^{\circ} \mathrm{C}$. 


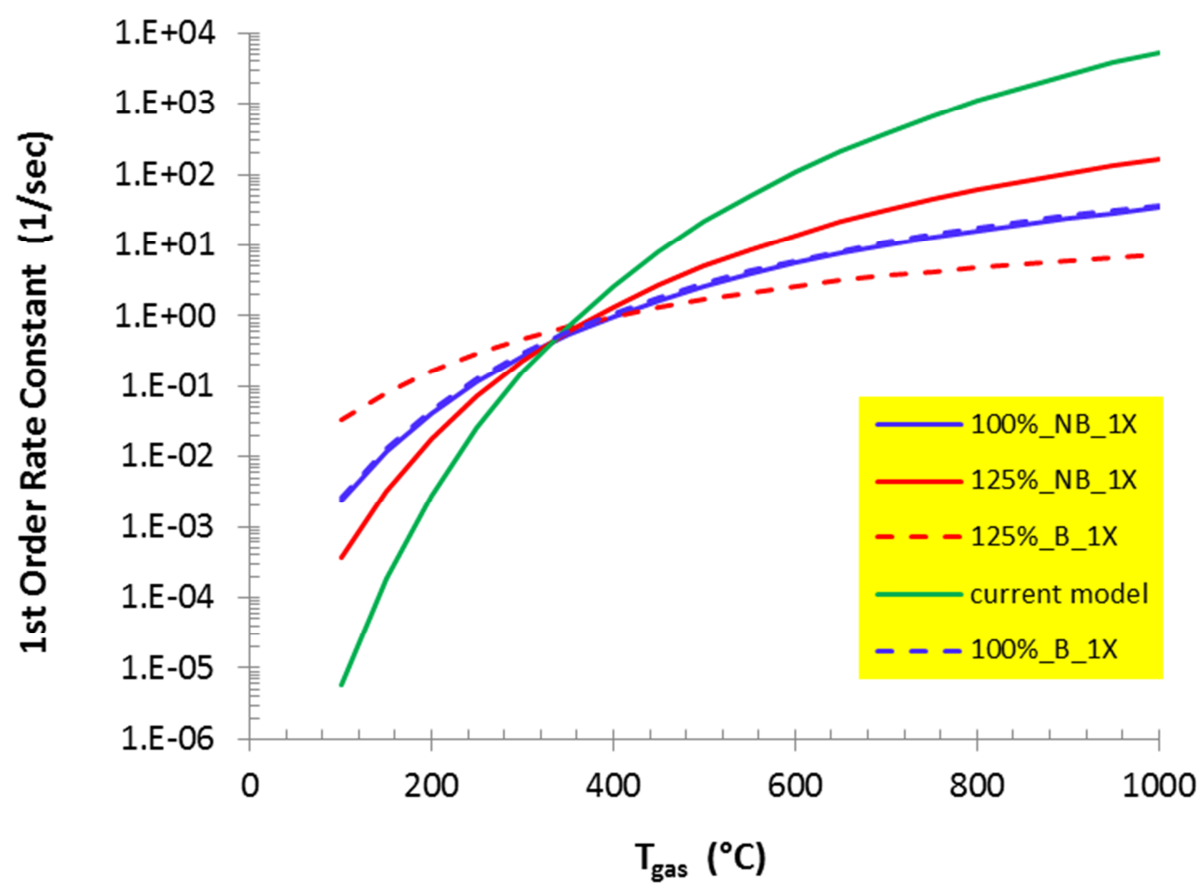

Figure 4-9. Profiles of First-Order Rate Constants of $\mathrm{H}_{2}$ Combustion.

\subsubsection{Off-Gas Surge Basis for the NGA Flowsheet}

The new model parameters discussed so far were inserted into the spreadsheet and used to predict the concentrations of $\mathrm{CO}$ and $\mathrm{H}_{2}$ during steady state operation just prior to the 13 " $\mathrm{H}_{2} \mathrm{O}$ pressure spike with the following average data: feed rate $=229.5 \mathrm{~g} / \mathrm{min}$, VS temperature $=685{ }^{\circ} \mathrm{C}$, VS pressure $=-5.35$ " $\mathrm{H}_{2} \mathrm{O}$. As shown in Table 4-8, the predicted $\mathrm{CO}$ concentration is $25 \%$ higher than the average FTIR data, just as it was targeted in the development of kinetic parameters of the glycolic acid decomposition. On the other hand, the predicted $\mathrm{H}_{2}$ concentration is shown to be $11 \%$ higher than the average MS data, which is lower than what it was targeted for in the development of its kinetic parameters. Both MS and $\mathrm{GC}$ readings of $\mathrm{H}_{2}$ remained within $\pm 5 \mathrm{ppm}$ of each other throughout the Phase 2 steady state runs, and it is not known why the GC readings were higher than usual during that period.

Table 4-8. Steady State and Bounding $\mathrm{H}_{2}$ and $\mathrm{CO}$ during $13 " \mathrm{H}_{2} \mathrm{O}$ Pressure Spike.

\begin{tabular}{|c|l|c|c|}
\hline Operating Mode & Variable & Data & Model \\
\hline \multirow{3}{*}{ Steady State } & $\mathrm{CO}(\mathrm{ppm})$ & 188 & 235 \\
\cline { 2 - 3 } & $\mathrm{H}_{2} \mathrm{GC}(\mathrm{ppm})$ & 60 & \multirow{2}{*}{51} \\
\cline { 2 - 3 } & $\mathrm{H}_{2} \mathrm{MS}(\mathrm{ppm})$ & 46 & \\
\hline \multirow{3}{*}{ Bounding } & $\mathrm{CO}(\mathrm{ppm})$ & 694 & 745 \\
\cline { 2 - 3 } & $\mathrm{H}_{2} \mathrm{GC}(\mathrm{ppm})$ & 215 & \multirow{2}{*}{488} \\
\cline { 2 - 3 } & $\mathrm{H}_{2} \mathrm{MS}(\mathrm{ppm})$ & 413 & \\
\hline
\end{tabular}


The spreadsheet was next used to predict the peak concentrations of $\mathrm{H}_{2}$ and $\mathrm{CO}$ during the 13" $\mathrm{H}_{2} \mathrm{O}$ pressure spike by assuming that the bounding system responses caused by the pressure spike but delayed by the transport, sampling and/or mixing lags had occurred simultaneously with the pressure spike. For example, the VS temperature did not reach its minimum until 1 min $49 \mathrm{sec}$ after the CEF pressure peaked at +8.3 " $\mathrm{H}_{2} \mathrm{O}$ but was assumed to have reached its minimum at the same time the pressure reached its maximum. As shown in Figure 2-3, the off-gas readings such as $\mathrm{CO}_{2}$ and $\mathrm{H}_{2}$ formed unusually broad peaks and reached their respective maxima $\sim 2 \min 45 \mathrm{sec}$ later; however, they were assumed to have reached their peaks at the same time as the pressure spike. The second smaller pressure spike that occurred $\sim 8$ min after the first showed more classical peaks of $\mathrm{CO}_{2}$ and $\mathrm{H}_{2}$ with a shorter delay time of 17 seconds. Finally, the magnitudes of condensable and non-condensable flow surges were determined by varying the flow rates of $\mathrm{H}_{2} \mathrm{O}$ vapor and $\mathrm{CO}_{2}$, respectively, until the calculated $\Delta \mathrm{P}$ across the film cooler and $\mathrm{CO}_{2}$ concentration in the off-gas matched their respective peak values shown in Figure 2-4.

The calculated concentrations of $\mathrm{CO}$ and $\mathrm{H}_{2}$ for this "bounding state" run are compared to their respective measured maxima in Table 4-8. The agreement between the model and data is seen to be quite good; the calculated $\mathrm{CO}$ and $\mathrm{H}_{2}$ concentrations are $7 \%$ and $18 \%$ higher than their respective data. Note that the $\mathrm{H}_{2} \mathrm{GC}$ reading for the bounding state cannot be considered accurate under these transient conditions due to its long sample time in minutes compared to that of MS in several seconds. Since the same $100 \%$ acid stoichiometry feed was used during the surge test, the fraction of nitrate removed remained unchanged at $22 \%$ and the overall balance between the oxidant (nitrate) and reductant (glycolate) also remained unchanged.

The results of the "bounding state" run also showed that the off-gas flow at the peak of the surge was equivalent to $12 \mathrm{X}$ normal condensable and $4 \mathrm{X}$ normal non-condensable flows. Compared to the existing $9 \mathrm{X} / 5 \mathrm{X}$ surge basis for the NFA flowsheet, this $12 \mathrm{X} / 4 \mathrm{X}$ surge will incur $33 \%$ higher condensable and 20\% lower non-condensable flows, and these two changes in flow work in the opposite directions so that the net effect on the off-gas flammability will be less than either alone. For example, an increase in the condensable flow lowers the combustion rate by decreasing the temperature and gas residence time in the vapor space, whereas a decrease in non-condensable flow means lower baseline concentrations of $\mathrm{CO}$ and $\mathrm{H}_{2}$. As stated in Section 2.3.2, the key attributes of the 13" $\mathrm{H}_{2} \mathrm{O}$ pressure spike profile shown in Figure 2-3 match well those of the design basis off-gas surge profile currently used in the model. As a result, it is recommended that the $12 \mathrm{X} / 4 \mathrm{X}$ surge be used as the baseline surge for the NGA flowsheet for bubbled operation.

\subsubsection{Overall Carbon Balance}

One of the major difficulties encountered during this study was achieving a reasonable carbon balance. As shown in Table 4-5, 19 out of 21 steady state runs had a negative carbon balance, i.e., the calculated total carbon flows in the off-gas were lower than those based on measured $\mathrm{CO}$ and $\mathrm{CO}_{2}$ typically by more than $20 \%$. In fact, those 3 steady state runs that were excluded from the model development had negative carbon balances ranging from -33 to $-42 \%$. Even for those two runs with non-negative carbon balances of near $0 \%$, it is suspected that steady state may not have been achieved in those runs because large fluctuations in the data forced the original 2-hr durations to be reduced to 1 hour or less in an effort to find the periods with less fluctuations. However, less fluctuating readings do not necessarily indicate that the system is at steady state unless those readings can be maintained for a sufficiently long period of time. Ideally, the calculated total carbon flows need to be somewhat higher than those measured (i.e., a positive carbon balance), thus leaving some carbon to account for the off-gas entrainment, which is confirmed even under non-bubbled conditions by the analytical results on the actual DWPF and CEF condensate samples. 
The large negative carbon balances shown consistently by the Phase 2 data are consistent with the results shown in Table 2-9 that the remediated feeds had up to $18 \%$ lower TOC than the measured values by DWPF Analytical even after assuming 100\% retention of the antifoam added during the SRAT processing. The accuracy of the TOC analysis by DWPF Analytical was confirmed against the total carbon emission data during batch melting of the same feeds in argon-purged crucibles. ${ }^{14}$ By contrast, all three total carbon estimates based on the IC, TOC analysis and crucible runs agreed well for the NFA flowsheet feed used in Phase 1 as well as the baseline SB8-D3 simulant, as shown in Table 2-4. If the TOC in the Phase 2 feeds were indeed under estimated, the firstorder global kinetic parameters derived for the glycolic acid decomposition and $\mathrm{H}_{2}$ combustion should be conservative. Regarding the empirical parameter added to exclude a portion of the total nitrate in the feed from the cold cap model input, under estimated TOC will decrease the fraction of nitrate to be removed, because it is set by matching measured $\mathrm{H}_{2}$ and $\mathrm{CO}$ concentrations at the lowest VS temperature of each steady state run, which are fixed regardless of the accuracy of the TOC measurement. Thus, if the same nitrate removal fraction is to be applied to a feed whose TOC is accurately known, the revised model will predict higher concentrations of $\mathrm{H}_{2}$ and $\mathrm{CO}$. Therefore, the effects of under estimated TOC on the global kinetic parameters and fractional nitrate removal are both conservative.

\subsubsection{Off-Gas Flammability of Phase 2 Feeds}

With the steady state mass and energy balance completed, the measured concentrations of $\mathrm{H}_{2}$ and $\mathrm{CO}$ were converted into the $\mathrm{H}_{2} / \mathrm{TOC}$ and $\mathrm{CO} / \mathrm{TOC}$ ratios, which are the measures of the relative flammability potential of each feed per carbon basis. In Figure 4-10 and Figure 4-11, the relative flammability potentials of the NFA flowsheet feed used in Phase 1 and that for the $100 \%$ NB_1X run are compared in terms of $\mathrm{H}_{2}$ and $\mathrm{CO}$, respectively. The 100\%_NB_1X run was chosen out of the 4 steady state run series of Phase 2 because the Phase 1 feed was prepared at $\sim 100 \%$ acid stoichiometry and run under non-bubbled condition.

It is shown that at $T_{\text {gas }}<\sim 440{ }^{\circ} \mathrm{C}$ each carbon in the NGA flowsheet feed produced about $1 / 4$ of the $\mathrm{H}_{2}$ produced by each carbon in the NFA flowsheet feed under non-bubbled operation. As $T_{\text {gas }}$ increased above $440{ }^{\circ} \mathrm{C}$, the difference between the $\mathrm{H}_{2}$ /TOC ratios of the two feeds narrowed quickly until they essentially became equal at $T_{\text {gas }}>500{ }^{\circ} \mathrm{C}$. Since the flammability assessment for the baseline off-gas surge is made at $T_{\text {gas }}<400{ }^{\circ} \mathrm{C}$, it can be concluded that per carbon basis the NGA flowsheet feed has only $1 / 4$ of the off-gas flammability potential of the NFA flowsheet feed, which is attributed to the fact that the former has a 3.6X higher nitrate (oxidant) than the latter. In Figure 4-11, the CO/TOC profile for the NGA flowsheet feed is shown to continuously decrease with decreasing temperature, while that of the NFA flowsheet feed started to level off at $T_{\text {gas }}=\sim 370^{\circ} \mathrm{C}$, thus rendering it more flammable than the NGA flowsheet feed. At $T_{\text {gas }}=300{ }^{\circ} \mathrm{C}$, each carbon in the NGA flowsheet feed produced about $1 / 2$ of the $\mathrm{CO}$ produced by each carbon in the NFA flowsheet feed under non-bubbled operation. As $T_{\text {gas }}$ increased above $370{ }^{\circ} \mathrm{C}$, the two $\mathrm{CO} / \mathrm{TOC}$ ratios remained essentially equal until $T_{\text {gas }}$ was near $500{ }^{\circ} \mathrm{C}$.

Although no direct comparison can be made for bubbled operation due to lack of the equivalent data for the NFA flowsheet feed (Phase 1), the same trends seen in Figure 4-10 and Figure 4-11 are expected to continue under bubbled conditions. Figure 4-12 clearly shows that both the $\mathrm{H}_{2}$ concentration and steady state feed rate are higher under bubbled than non-bubbled conditions at all $T_{\text {gas }}$, which suggests that the higher $\mathrm{H}_{2}$ concentration under bubbled conditions is likely due to increased feed rate induced by the bubbling at a fixed air purge rate. 


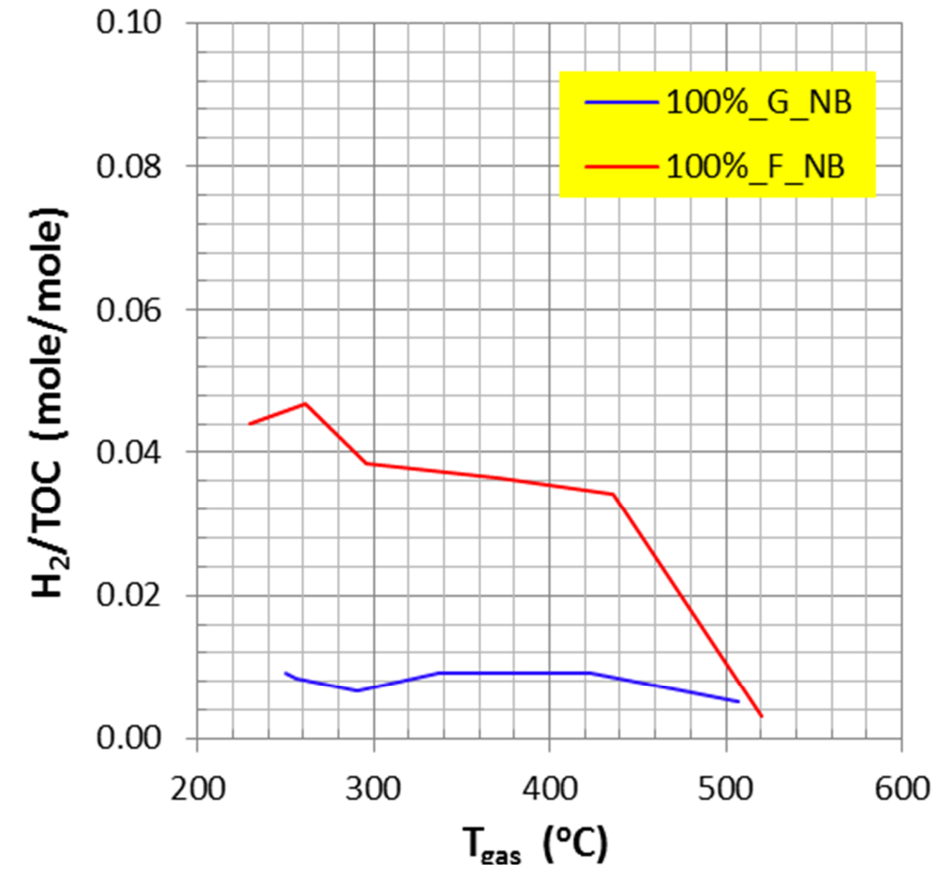

Figure 4-10. Measured $\mathrm{H}_{2}$ /TOC Ratios of Phase 1 vs. Phase 2 Feed.

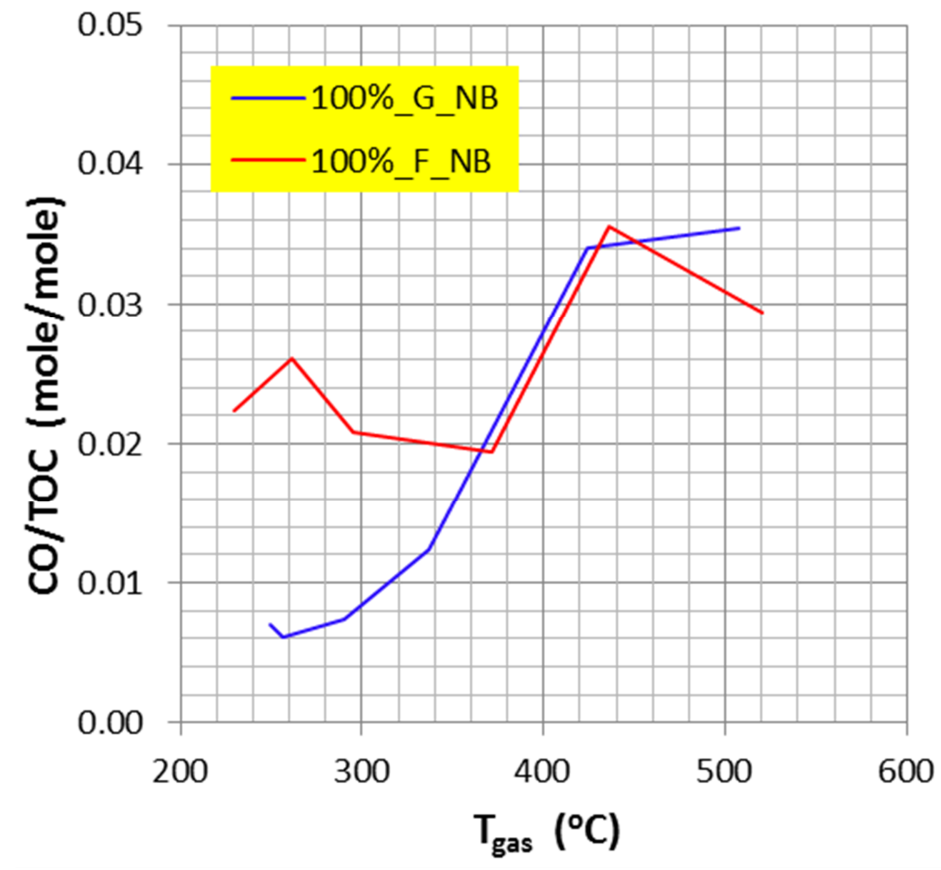

Figure 4-11. Measured CO/TOC Ratios of Phase 1 vs. Phase 2 Feed. 

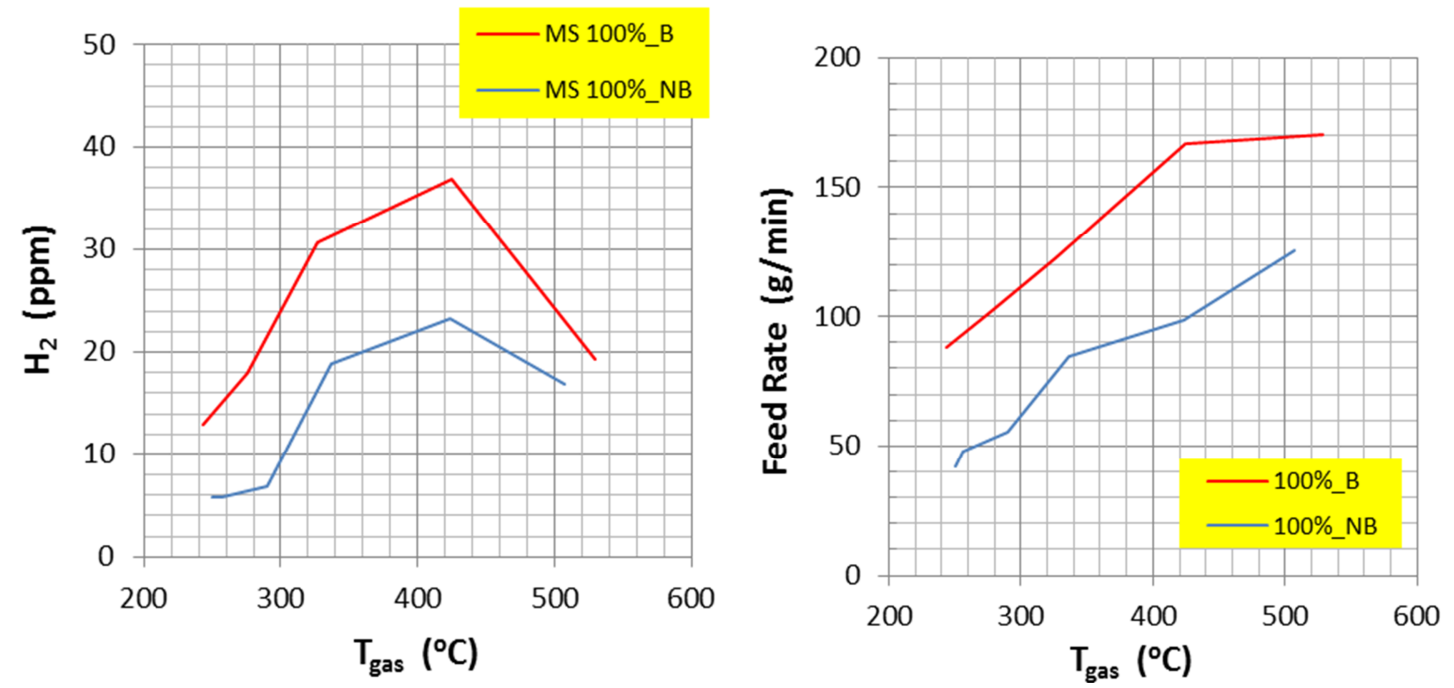

Figure 4-12. Impact of Bubbling on $\mathrm{H}_{2}$ and Feed Rate (100\% Acid).

\subsection{Some Thoughts on Redox}

Table 4-9 lists measured and calculated redox values of both NFA and NGA flowsheet feeds tested during Phase 1, Phase 2, and batch-melting tests in argon-purged crucibles. Note that the given $\mathrm{TOC}$ values are identical to those of $\mathrm{TOC}_{\text {cruc }}$ in Table 2-4; they were calculated by summing up the carbon species emitted from argon-purged crucibles. It is striking to see how widely the various redox measurements on the Phase 1 feed varied. The highest redox of 0.638 was measured from the remaining glass after a $10 \mathrm{~g}$ batch of Phase 1 feed was boiled, calcined and melted in an argon-purged crucible. Argon purging eliminated the potential for air inleakage and further helped purge out any calcine gases emitted from the batch. Due to the small batch size, however, there is also a possibility that argon purging may not have allowed enough time for gases to undergo cold cap equilibrium reactions with solids before being swept away.

Table 4-9. Comparison of Redox of Phase 1 and Phase 2 Feeds.

\begin{tabular}{|c|c|c|c|c|c|c|}
\hline \multirow[b]{2}{*}{ Feed } & \multirow[b]{2}{*}{ Reductant } & \multirow[b]{2}{*}{$\begin{array}{c}\mathrm{TOC} \\
(\mathrm{mg} / \mathrm{kg})\end{array}$} & \multicolumn{4}{|c|}{ Redox } \\
\hline & & & $\begin{array}{l}\text { Ar-purged } \\
\text { crucible }\end{array}$ & $\begin{array}{l}\text { closed } \\
\text { crucible }\end{array}$ & $\begin{array}{c}\mathrm{CC} \\
\text { model }\end{array}$ & $\begin{array}{l}\text { CEF } \\
\text { glass }\end{array}$ \\
\hline CEF1_Baseline & Formic & 12,789 & 0.638 & 0.260 & 0.45 & $0.08-0.2$ \\
\hline CEF1_Baseline_1\% $\mathrm{O}_{2}$ in Ar purge & “" & 13,392 & 0 & - & - & - \\
\hline SB8-D3_Baseline & “" & 17,209 & 0.300 & 0.210 & 0.11 & - \\
\hline SB8-D3_1600ppm-AC Spike_Fresh & “" & 17,311 & 0.494 & - & - & - \\
\hline SB8-D3_1600ppm-AC Spike_Boiled & “" & 18,315 & 0.484 & - & - & - \\
\hline SB8-D3_1600ppm-PEG C Spike_Boiled & “" & 20,610 & 0.461 & - & - & - \\
\hline CEF2_100\% Acid_Baseline & Glycolic & 16,178 & 0.269 & 0.251 & 0.11 & 0 \\
\hline CEF2_100\% Acid_1000ppm AC Spike & “" & 15,623 & 0.224 & - & - & $"$ \\
\hline CEF2_100\% Acid_1476ppm AC Spike & “" & - & 0.566 & 0.439 & - & $"$ \\
\hline
\end{tabular}


On the other hand, the probability of such gas-solids reactions occurring in the batch is higher in closed crucibles, which may provide a partial explanation to its lower redox of 0.26 . However, a certain degree of uncertainty seems to exist regarding the effectiveness of the sealant in terms of eliminating air inleakage but still allowing calcine gases to exit. If the calcine gases are prevented from leaving freely, it can lead to the "over-equilibrium" situation, which is not the accurate depiction of the actual cold cap either. Therefore, it is not certain whether the reduced redox by more than $50 \%$ reflects the true state of feed chemistry. Interestingly, the current cold cap model predicted the redox that lies exactly at the midpoint of the two aforementioned values.

The redox of glass samples pulled from the CEF during Phase 1 ranged from 0.08 and 0.2 , as measured in closed crucibles. As noted elsewhere, ${ }^{8}$ the high end of this redox range occurred during feeding with active argon bubbling of the melt pool, while the lower end occurred during non-bubbled testing at low feed rates. In fact, had the feeding been continued, the upper bound could have been pushed higher and may have approached a value near the closed crucible data. However, the closed crucible data was obtained without bubbling so the two redox values are not directly comparable. When the argon purge was mixed with air at a target of $1 \% \mathrm{O}_{2}$, the resulting glass was completely oxidizing, indicating a redox drop of at least 0.638 . This result shows how strong an effect the gas phase above the cold cap has on the cold cap chemistry and redox. It is interesting to note that the TOC values estimated from the carbon emission data for the first two CEF1 cases in Table 4-9 differ by 5\%, despite the fact that the same feed was used in both cases.

When a $10 \mathrm{~g}$ batch of SB8-D3 slurry, also based on the NFA flowsheet, was melted in an argonpurged crucible, the resulting glass proved more oxidizing than the Phase 1 glass despite the fact the former feed had a 35\% higher TOC than the latter. This can be explained by the difference in nitrate, as shown in Table 2-4; the SB8-D3 had a 74\% higher nitrate than the Phase 1 feed. The redox measured in closed crucible was also lower but by only 0.05 compared to a decrease of 0.34 in argon-purged crucible. The cold cap model also predicted a lower redox for the SB8=D3 glass and the magnitude of decrease was exactly the same at 0.34 . As expected, the glasses made from the next three SB8-D3 feeds spiked with additional carbons in argon-purged crucibles were all similarly reducing at a redox of just under 0.5 .

When the $100 \%$ acid stoichiometry NGA flowsheet feed used in Phase 2 were melted in argonpurged and closed crucibles, both glasses had nearly the same redox, 0.27 vs. 0.25 . The cold cap model predicted more oxidizing glass at a redox of 0.11, as shown in Table 4-3. However, the glass samples pulled during Phase 2 were all completely oxidizing except for the few samples taken early on; glass remained completely oxidizing even with feeds spiked with $2 \mathrm{X}$ antifoam, while the melt pool was continuously agitated with argon bubbling. Glass did not go completely oxidizing in Phase 1 under the same operating conditions, including air inleakage. The difference between Phase 1 and Phase 2 runs was primarily in the feed chemistry, the formic vs. glycolic in reductant space but, more importantly, the amount of nitrate required by each reductant carbon.

When the same Phase 2 feed was spiked with 1,000 ppm of antifoam carbon, the resulting glass is shown to be a little more oxidizing than the un-spiked feed. This was unexpected because at a fixed nitrate level the redox balance of the feed had to be shifted in the direction of higher redox. An additional support for this is shown in Figure 2-2; the total $\mathrm{H}_{2}$ emissions from the spiked and un-spiked feeds were exactly the same despite the fact that the spiked feed contained excess $\mathrm{H}_{2}$ that came with excess antifoam. This can only happen when additional $\mathrm{O}_{2}$ is taken from the nitrate to oxidize the excess $\mathrm{H}_{2}$, which would subsequently lower redox. This is exactly the case with the next feed containing an additional $476 \mathrm{ppm}$ of antifoam carbon over this feed; the resulting increase in redox was substantial, and the closed crucible glasses were not as reducing. 


\subsection{Conclusions and Recommendations}

Based on the results of the CEF Phase 2 data analysis and model revision discussed so far, the following conclusions are drawn:

1. In the temperature range relevant to the DWPF melter off-gas flammability safety basis, the NGA flowsheet feed produces $1 / 4$ of the $\mathrm{H}_{2}$ produced by the NFA flowsheet feed on a per carbon basis.

2. A new off-gas surge basis has been defined for the NGA flowsheet; it consists of $12 \mathrm{X}$ normal condensable and $4 \mathrm{X}$ normal non-condensable flows $(12 \mathrm{X} / 4 \mathrm{X})$ for bubbled operation. For non-bubbled operation, the existing surge basis of $3 \mathrm{X}$ normal condensable and $3 \mathrm{X}$ normal non-condensable $(3 \mathrm{X} / 3 \mathrm{X})$ for the NFA flowsheet is still bounding.

3. The DWPF melter off-gas flammability model has been revised for the NGA flowsheet its new parameters are set to match $125 \%$ of the measured $\mathrm{H}_{2}$ and $\mathrm{CO}$ concentrations during Phase 2 as a conservative measure.

4. The existing correlation used to estimate the true gas temperature in the DWPF melter vapor space from the measured data (TI4085D) for the combustion kinetics calculations is conservative, which confirms the earlier findings of the Phase 1 study.

5. There is a high probability that the current analytical method used to detect the glycolate is under reporting it by a significant margin.

It is also recommended that:

1. The current analytical method for detecting the glycolate be improved.

2. The new parameters added to the revised DWPF melter off-gas flammability model be validated prior to performing Type 1 calculations.

3. Additional small-scale tests be run using both argon-purged and closed crucibles or any variations of them to study the impact of varying carbon and nitrate on the redox and $\mathrm{H}_{2}$ generation. 
SRNL-STI-2014-00355

Revision 0

\subsection{References}

1. Wagnon, T. J., "Defense Waste Processing Facility Alternate Reductant Systems Engineering Evaluation," G-AES-S-00003, Rev. 0, Savannah River Remediation, Aiken, SC, August 3, 2011.

2. Johnson, F. C, and Miller, D. H., "Nitric-Glycolic Acid Melter Flammability Testing 2013 Phase 2 CEF Run R\&D Directions," SRNL-L3100-2014-00007, Savannah River National Laboratory, Aiken, SC, January 18, 2014.

3. Johnson, F. C., Stone, M. E., and Miller, D. H., "Alternate Reductant Cold Cap Evaluation Furnace Phase II Testing," Savannah River National Laboratory, Aiken, SC, SRNL-STI2014-00157, September 2014.

4. Choi, A. S., "Melter Off-Gas Flammability Assessment for DWPF Alternate Reductant Flowsheet Options," SRNL-STI-2011-00321, Rev. 0, Savannah River National Laboratory, Aiken, SC, July 2011.

5. Choi, A. S., and Lee, S. Y., "Impact of Melter Internal Design on Off-Gas Flammability," SRNL-STI-2012-00121, Rev. 0, Savannah River National Laboratory, Aiken, SC, May 2012.

6. Choi, A. S., "DWPF MOG Flammability Assessment," X-CLC-S-00164, Rev. 4, August 2010.

7. Abramowitz1, H., Calloway, B., Mecholsky N., D’Angelo1, N., Windham, J., and Coleman, J., "Analysis of Bubbled vs. Non-Bubbled DWPF Operating Data," A Joint Report by Savannah River Remediation (Aiken, SC), Vitreous State Laboratory of The Catholic University of America (Washington, D.C.), and Savannah River National Laboratory (Aiken, SC), June 6, 2013.

8. Choi, A. S., "2013 CEF Run - Phase 1 Data Analysis and Model Validation," SRNL-STI2013-00705, Rev. 0, Savannah River National Laboratory, Aiken, SC, April 2014.

9. Lambert, D. P., "Batching Recipe: 100\% Koopman Acid Stoichiometry Nitric/Glycolic Acid Flowsheet Melter Feed," SRNL-L3100-2013-00036, Savannah River National Laboratory, Aiken, SC, June 19, 2013.

10. Lambert, D. P., "Batching Recipe: 125\% Koopman Acid Stoichiometry Nitric/Glycolic Acid Flowsheet Melter Feed," SRNL-L3100-2013-00064, Savannah River National Laboratory, Aiken, SC, June 19, 2013.

11. Choi, A. S., "DWPF MOG Flammability Assessment (Sludge Batch 8)," X-CLC-S-00164, Rev. 8, March 2013.

12. Lambert, D. P., "Acceptance of Harrell Batch 6B61 100\% Glycolic Nitric Acid Flowsheet SRAT Product," SRNL-L3100-2013-00118, Savannah River National Laboratory, Aiken, SC, July 24, 2013. 
13. Lambert, D. P., "Acceptance of Harrell Batch 6B61 125\% Glycolic Nitric Acid Flowsheet SRAT Product," SRNL-L3100-2013-00146, Savannah River National Laboratory, Aiken, SC, September 9, 2013.

14. Amoroso, J. W., and Zamecnik, J. R., "Measurement of Offgas Species from Thermal Decomposition of Simulated DWPF Melter Feed," SRNL-STI-2014-00286, Savannah River National Laboratory, Aiken, SC, September 2014.

15. Koopman, D. C., and Zamecnik, J. R., "DWPF Simulant CPC Studies for SB8," SRNL-STI2013-00106, Savannah River National Laboratory, Aiken, SC, June 2013.

16. Choi, A. S., "DWPF MOG Flammability Assessment (Sludge Batch 6 and 7A)," $\boldsymbol{X}$-CLC-S00164, Rev. 5, August 2011.

17. Jantzen, C. M., and Johnson, F. C., "Impacts of Antifoam Additions and Argon Bubbling on Defense Waste Processing Facility (DWPF) REDuction/OXidation (REDOX)," SRNL-STI2011-00652, Rev. 0, June 2012.

18. Choi, A. S., "Validation of DWPF Melter Off-Gas Combustion Model," WSRC-TR-200000100, Westinghouse Savannah River Co., Aiken, SC, June 23, 2000.

19. Choi, A. S., "Validation of DWPF MOG Dynamics Model - Phase I (U),"WSRC-TR-960307, Westinghouse Savannah River Co., Aiken, SC, January 7, 1997.

20. Plante, E. R., Bonnell, D. W., and Hastie, J. W., "Experimental and Theoretical Determination of Oxide Glass Vapor Pressures and Activities," Advances in the Fusion of Glass, Am. Cer. Soc., pp 26.1-26.18 (1988).

21. Flow of Fluids through Valves, Fittings, and Pipe, Technical Paper No. 410, Crane Co. (1988).

22. Schutte \& Koerting, Bulletin 7-S, Performance Curve for Fig. 7009 3-Inch Scrubber (2008).

23. Octave Levenspiel, Chemical Reaction Engineering, $3^{\text {rd }}$ Ed., Wiley (1998).

24. Stone, M. E., "Feed Preparation for Alternate Reductant Melter Testing," SRNL-L31002013-00109, Savannah River National Laboratory, Aiken, SC, June 20, 2013. 
SRNL-STI-2014-00355

Revision 0

Appendix A.

Steady State Operating Data during CEF Phase 2 Run 
Table A-1. Steady State Data for the Bubbled Run with 125\% Acid Stoichiometry Feed with 1X Antifoam (SS_125\%_B_1X).

\begin{tabular}{|c|c|c|c|c|c|c|c|c|c|c|c|c|c|c|c|}
\hline & $\begin{array}{c}\text { VS } \\
\text { Temp }\end{array}$ & $\begin{array}{l}\text { Feed } \\
\text { Rate }\end{array}$ & $\begin{array}{l}\text { FC } \\
\text { Air }\end{array}$ & $\begin{array}{l}\text { Cam } \\
\text { Air }\end{array}$ & $\begin{array}{l}\text { VS } \\
\text { Air }\end{array}$ & $\begin{array}{c}\text { FC } \\
\text { Exit } \mathbf{T}\end{array}$ & $\begin{array}{c}\text { CEF } \\
\text { P }\end{array}$ & $\begin{array}{c}\text { FC } \\
\text { Exit P }\end{array}$ & $\begin{array}{l}\text { Glass } \\
\text { Temp }\end{array}$ & $\begin{array}{c}\text { H2 } \\
(\mathrm{MS})\end{array}$ & $\begin{array}{c}\text { CO } \\
\text { (FTIR) }\end{array}$ & $\begin{array}{l}\text { CO2 } \\
\text { (MS) }\end{array}$ & $\begin{array}{c}\text { NO } \\
\text { (MS) }\end{array}$ & $\begin{array}{l}\text { NO2 } \\
\text { (MS) }\end{array}$ & $\begin{array}{c}\text { N2O } \\
\text { (FTIR) }\end{array}$ \\
\hline & $\left({ }^{\circ} \mathrm{C}\right)$ & (g/min) & (scfm) & (scfm) & (scfm) & $\left({ }^{\circ} \mathrm{C}\right)$ & ("wc) & ("wc) & $\left({ }^{\circ} \mathrm{C}\right)$ & (ppm) & (ppm) & (vol\%) & (ppm) & (ppm) & (ppm) \\
\hline average & 705 & 221.38 & 15.64 & 8.50 & 0.65 & 366 & -5.22 & -5.97 & 1,033 & 43 & 224 & 0.9187 & 2,183 & 1,430 & 391 \\
\hline std dev & 8 & & 0.08 & & 0.00 & 6 & 0.21 & 0.17 & 7 & 13 & 66 & 0.1582 & 225 & 391 & 84 \\
\hline $\max$ & 722 & & 15.83 & & 0.66 & 385 & -4.44 & -5.36 & 1,045 & 88 & 494 & 1.4827 & 2,425 & 2,804 & 670 \\
\hline $\min$ & 683 & & 15.44 & & 0.62 & 357 & -5.58 & -6.26 & 1,021 & 25 & 151 & 0.6992 & 1,327 & 638 & 271 \\
\hline average & 625 & 161.29 & 15.92 & 8.41 & 0.68 & 299 & -5.35 & -5.99 & 1,032 & 70 & 180 & 0.6758 & 1,898 & 981 & 266 \\
\hline std dev & 12 & & 0.07 & & 0.01 & 8 & 0.18 & 0.15 & 7 & 16 & 54 & 0.0695 & 155 & 137 & 48 \\
\hline $\max$ & 644 & & 16.11 & & 0.69 & 319 & -4.75 & -5.51 & 1,045 & 110 & 418 & 0.9901 & 2,346 & 1,627 & 429 \\
\hline $\min$ & 605 & & 15.76 & & 0.66 & 286 & -5.67 & -6.26 & 1,018 & 43 & 105 & 0.5618 & 1,628 & 798 & 181 \\
\hline average & 481 & 113.53 & 15.88 & 8.27 & 15.12 & 256 & -4.90 & -6.20 & 1,025 & 42 & 32 & 0.3115 & 917 & 388 & 106 \\
\hline std dev & 7 & & 0.08 & & 0.05 & 4 & 0.29 & 0.29 & 4 & 11 & 10 & 0.0288 & 84 & 32 & 17 \\
\hline $\max$ & 496 & & 16.14 & & 15.22 & 266 & -4.01 & -5.39 & 1,036 & 88 & 91 & 0.4413 & 1,296 & 523 & 183 \\
\hline $\min$ & 471 & & 15.65 & & 15.00 & 251 & -5.42 & -6.70 & 1,016 & 23 & 18 & 0.2531 & 749 & 318 & 80 \\
\hline average & 415 & 110.95 & 16.08 & 8.20 & 22.28 & 234 & -4.74 & -6.42 & 1,029 & 28 & 23 & 0.2451 & 793 & 364 & 90 \\
\hline std dev & 5 & & 0.06 & & 0.04 & 2 & 0.15 & 0.14 & 5 & 10 & 7 & 0.0306 & 120 & 48 & 17 \\
\hline $\max$ & 425 & & 16.22 & & 22.38 & 238 & -4.27 & -5.94 & 1,039 & 75 & 53 & 0.3784 & 1,336 & 577 & 169 \\
\hline $\min$ & 403 & & 15.92 & & 22.19 & 226 & -5.09 & -6.73 & 1,021 & 12 & 13 & 0.1974 & 600 & 289 & 61 \\
\hline average & 360 & 92.88 & 8.54 & 8.21 & 40.14 & 244 & -3.48 & -5.91 & 1,011 & 18 & 22 & 0.1832 & 498 & 228 & 68 \\
\hline std dev & 9 & & 0.04 & & 0.06 & 5 & 0.29 & 0.26 & 4 & 6 & 8 & 0.0295 & 107 & 35 & 19 \\
\hline $\max$ & 377 & & 8.63 & & 40.32 & 250 & -2.63 & -5.18 & 1,021 & 32 & 42 & 0.2605 & 806 & 327 & 108 \\
\hline $\min$ & 344 & & 8.43 & & 39.98 & 235 & -4.15 & -6.55 & 1,005 & 4 & 6 & 0.1148 & 302 & 162 & 36 \\
\hline average & 270 & 72.15 & 6.20 & 8.08 & 50.68 & 203 & -1.16 & -3.85 & 1,035 & 19 & 19 & 0.1617 & 441 & 184 & 59 \\
\hline std dev & 8 & & 0.03 & & 0.08 & 4 & 0.22 & 0.20 & 3 & 5 & 8 & 0.0237 & 87 & 26 & 16 \\
\hline $\max$ & 282 & & 6.27 & & 50.92 & 211 & -0.49 & -3.27 & 1,042 & 38 & 43 & 0.2162 & 676 & 246 & 100 \\
\hline $\min$ & 251 & & 6.10 & & 50.50 & 194 & -1.67 & -4.29 & 1,027 & 8 & 3 & 0.1053 & 246 & 124 & 27 \\
\hline
\end{tabular}


Table A-2. Steady State Data for the Non-Bubbled Run with 125\% Acid Stoichiometry Feed with 1X Antifoam (SS_125\%_NB_1X).

\begin{tabular}{|c|c|c|c|c|c|c|c|c|c|c|c|c|c|c|c|}
\hline & $\begin{array}{c}\text { VS } \\
\text { Temp } \\
\end{array}$ & $\begin{array}{l}\text { Feed } \\
\text { Rate } \\
\end{array}$ & $\begin{array}{l}\text { FC } \\
\text { Air } \\
\end{array}$ & $\begin{array}{c}\text { Cam } \\
\text { Air } \\
\end{array}$ & $\begin{array}{l}\text { VS } \\
\text { Air } \\
\end{array}$ & $\begin{array}{c}\text { FC } \\
\text { Exit T } \\
\end{array}$ & $\begin{array}{c}\text { CEF } \\
\mathbf{P} \\
\end{array}$ & $\begin{array}{c}\text { FC } \\
\text { Exit } \mathbf{P} \\
\end{array}$ & $\begin{array}{l}\text { Glass } \\
\text { Temp } \\
\end{array}$ & $\begin{array}{c}\text { H2 } \\
\text { (MS) }\end{array}$ & $\begin{array}{c}\text { CO } \\
\text { (FTIR) }\end{array}$ & $\begin{array}{l}\text { CO2 } \\
(\mathrm{MS}) \\
\end{array}$ & $\begin{array}{c}\text { NO } \\
\text { (MS) } \\
\end{array}$ & $\begin{array}{l}\text { NO2 } \\
\text { (MS) } \\
\end{array}$ & $\begin{array}{c}\text { N2O } \\
\text { (FTIR) }\end{array}$ \\
\hline & $\left({ }^{\circ} \mathrm{C}\right)$ & $(\mathrm{g} / \mathrm{min})$ & $(\mathrm{scfm})$ & (scfm) & $(\mathrm{scfm})$ & $\left({ }^{\circ} \mathrm{C}\right)$ & ("wc) & ("wc) & $\left({ }^{\circ} \mathrm{C}\right)$ & (ppm) & (ppm) & (vol\%) & (ppm) & (ppm) & $(\mathrm{ppm})$ \\
\hline average & 302 & 35.08 & 15.91 & 8.14 & 29.62 & 183 & -4.96 & -6.81 & 1,084 & 12 & 6 & 0.1186 & 332 & 213 & 32 \\
\hline std dev & 1 & 0.00 & 0.07 & & 0.93 & 0 & 0.39 & 0.33 & 2 & 1 & 2 & 0.0078 & 46 & 18 & 5 \\
\hline $\max$ & 303 & 0.00 & 16.08 & & 30.33 & 184 & -3.59 & -5.56 & 1,088 & 17 & 13 & 0.1322 & 434 & 252 & 44 \\
\hline $\min$ & 301 & 0.00 & 15.77 & & 28.05 & 183 & -5.52 & -7.25 & 1,081 & 9 & 3 & 0.0986 & 252 & 181 & 22 \\
\hline average & 351 & 44.27 & 15.93 & 8.19 & 20.89 & 200 & -5.04 & -6.43 & 1,083 & 16 & 11 & 0.1566 & 374 & 279 & 56 \\
\hline std dev & 5 & 0.00 & 0.08 & & 0.35 & 2 & 0.19 & 0.17 & 2 & 8 & 5 & 0.0335 & 105 & 55 & 17 \\
\hline $\max$ & 363 & 0.00 & 16.21 & & 20.99 & 205 & -4.70 & -6.12 & 1,087 & 51 & 31 & 0.2217 & 640 & 419 & 99 \\
\hline $\min$ & 343 & 0.00 & 15.69 & & 14.96 & 197 & -7.71 & -8.84 & 1,078 & 3 & 1 & 0.0911 & 174 & 174 & 24 \\
\hline average & 393 & 51.07 & 15.73 & 8.13 & 14.98 & 212 & -5.46 & -6.56 & 1,085 & 23 & 14 & 0.1885 & 517 & 275 & 75 \\
\hline std dev & 8 & 0.00 & 0.08 & & 0.04 & 4 & 0.10 & 0.09 & 3 & 10 & 7 & 0.0434 & 135 & 54 & 25 \\
\hline $\max$ & 409 & 0.00 & 15.97 & & 15.06 & 219 & -4.97 & -6.15 & 1,090 & 82 & 56 & 0.3893 & 1,149 & 502 & 195 \\
\hline $\min$ & 377 & 0.00 & 15.50 & & 14.87 & 205 & -5.70 & -6.79 & 1,079 & 6 & 3 & 0.0856 & 120 & 117 & 21 \\
\hline average & 486 & 87.60 & 15.89 & 8.44 & 0.28 & 217 & -5.51 & -6.16 & 1,059 & 83 & 55 & 0.4312 & 1,275 & 704 & 189 \\
\hline std dev & 5 & 0.00 & 0.05 & & 0.01 & 4 & 0.11 & 0.10 & 7 & 30 & 17 & 0.0918 & 330 & 195 & 59 \\
\hline $\max$ & 500 & 0.00 & 16.04 & & 0.31 & 228 & -5.09 & -5.81 & 1,073 & 138 & 122 & 0.6996 & 2,210 & 1,288 & 389 \\
\hline $\min$ & 478 & 0.00 & 15.77 & & 0.25 & 209 & -5.76 & -6.37 & 1,044 & 29 & 19 & 0.2477 & 652 & 382 & 83 \\
\hline average & 604 & 105.85 & 16.04 & 8.56 & 0.25 & 279 & -5.29 & -6.00 & 1,060 & 46 & 119 & 0.4400 & 1,377 & 824 & 222 \\
\hline std dev & 3 & 0.00 & 0.05 & & 0.01 & 3 & 0.09 & 0.08 & 4 & 10 & 32 & 0.0727 & 242 & 168 & 50 \\
\hline $\max$ & 610 & 0.00 & 16.18 & & 0.28 & 286 & -5.01 & -5.78 & 1,070 & 86 & 221 & 0.7327 & 2,250 & 1,462 & 390 \\
\hline $\min$ & 598 & 0.00 & 15.88 & & 0.23 & 273 & -5.47 & -6.15 & 1,053 & 23 & 67 & 0.2552 & 927 & 430 & 138 \\
\hline average & 709 & 99.60 & 15.73 & 8.30 & 0.45 & 325 & -5.47 & -6.02 & 1,083 & 13 & 119 & 0.4308 & 1,360 & 607 & 219 \\
\hline std dev & 3 & 0.00 & 0.07 & & 0.01 & 2 & 0.09 & 0.08 & 6 & 5 & 28 & 0.0629 & 201 & 106 & 42 \\
\hline $\max$ & 716 & 0.00 & 15.89 & & 0.47 & 333 & -5.21 & -5.74 & 1,096 & 29 & 217 & 0.6064 & 2,003 & 956 & 356 \\
\hline $\min$ & 703 & 0.00 & 15.58 & & 0.41 & 322 & -5.66 & -6.18 & 1,075 & 7 & 72 & 0.3191 & 1,004 & 443 & 149 \\
\hline
\end{tabular}


Table A-3. Steady State Data for the Non-Bubbled Run with 100\% Acid Stoichiometry Feed with 1X Antifoam (SS_100\%_NB_1X).

\begin{tabular}{|c|c|c|c|c|c|c|c|c|c|c|c|c|c|c|c|}
\hline & $\begin{array}{c}\text { VS } \\
\text { Temp }\end{array}$ & $\begin{array}{l}\text { Feed } \\
\text { Rate }\end{array}$ & $\begin{array}{l}\text { FC } \\
\text { Air }\end{array}$ & $\begin{array}{c}\text { Cam } \\
\text { Air }\end{array}$ & $\begin{array}{l}\text { VS } \\
\text { Air } \\
\end{array}$ & $\begin{array}{c}\text { FC } \\
\text { Exit T } \\
\end{array}$ & $\begin{array}{c}\text { CEF } \\
\mathbf{P}\end{array}$ & $\begin{array}{c}\text { FC } \\
\text { Exit } \mathbf{P} \\
\end{array}$ & $\begin{array}{l}\text { Glass } \\
\text { Temp } \\
\end{array}$ & $\begin{array}{c}\text { H2 } \\
(\mathrm{MS})\end{array}$ & $\begin{array}{c}\text { CO } \\
\text { (FTIR) }\end{array}$ & $\begin{array}{l}\mathrm{CO2} \\
(\mathrm{MS})\end{array}$ & $\begin{array}{c}\text { NO } \\
\text { (MS) }\end{array}$ & $\begin{array}{l}\text { NO2 } \\
\text { (MS) } \\
\end{array}$ & $\begin{array}{c}\text { N2O } \\
\text { (FTIR) }\end{array}$ \\
\hline & $\left({ }^{\circ} \mathrm{C}\right)$ & $(\mathrm{g} / \mathrm{min})$ & (scfm) & (scfm) & (scfm) & $\left({ }^{\circ} \mathrm{C}\right)$ & ("wc) & ("wc) & $\left({ }^{\circ} \mathrm{C}\right)$ & (ppm) & (ppm) & (vol\%) & (ppm) & (ppm) & $(\mathrm{ppm})$ \\
\hline average & 697 & 125.22 & 16.14 & 8.07 & 0.32 & 323 & -5.27 & -5.77 & 1,086 & 17 & 117 & 0.4755 & 1,445 & 671 & 152 \\
\hline std dev & 5 & 0.00 & 0.11 & & 0.01 & 3 & 0.10 & 0.08 & 4 & 4 & 26 & 0.0551 & 163 & 93 & 28 \\
\hline $\max$ & 708 & 0.00 & 16.44 & & 0.32 & 328 & -5.00 & -5.53 & 1,096 & 28 & 242 & 0.6445 & 2,001 & 989 & 241 \\
\hline $\min$ & 688 & 0.00 & 15.87 & & 0.30 & 316 & -5.52 & -5.99 & 1,080 & 8 & 65 & 0.3293 & 1,027 & 382 & 93 \\
\hline average & 600 & 98.54 & 16.55 & 8.09 & 0.32 & 268 & -5.70 & -6.15 & 1,085 & 23 & 85 & 0.3550 & 1,137 & 518 & 125 \\
\hline std dev & 5 & 0.00 & 0.09 & & 0.01 & 2 & 0.09 & 0.08 & 4 & 6 & 30 & 0.0708 & 186 & 95 & 33 \\
\hline $\max$ & 614 & 0.00 & 16.79 & & 0.35 & 273 & -5.27 & -5.79 & 1,092 & 44 & 196 & 0.6306 & 2,033 & 1,044 & 289 \\
\hline $\min$ & 593 & 0.00 & 16.23 & & 0.30 & 263 & -5.93 & -6.35 & 1,074 & 14 & 40 & 0.2395 & 802 & 360 & 78 \\
\hline average & 496 & 84.48 & 16.80 & 8.09 & 0.33 & 214 & -6.00 & -6.42 & 1,068 & 19 & 26 & 0.2967 & 993 & 455 & 96 \\
\hline std dev & 5 & 0.00 & 0.07 & & 0.01 & 4 & 0.11 & 0.10 & 5 & 9 & 15 & 0.0749 & 215 & 105 & 37 \\
\hline $\max$ & 507 & 0.00 & 17.00 & & 0.36 & 226 & -5.52 & -6.00 & 1,078 & 55 & 95 & 0.6123 & 2,067 & 1,027 & 261 \\
\hline $\min$ & 488 & 0.00 & 16.58 & & 0.32 & 208 & -6.21 & -6.61 & 1,059 & 6 & 9 & 0.1976 & 668 & 319 & 56 \\
\hline average & 410 & 55.75 & 16.83 & 8.05 & 13.22 & 209 & -5.46 & -6.49 & 1,074 & 7 & 8 & 0.1210 & 502 & 244 & 634 \\
\hline std dev & 5 & 0.00 & 0.10 & & 0.03 & 3 & 0.11 & 0.10 & 5 & 4 & 4 & 0.0240 & 93 & 32 & 119 \\
\hline $\max$ & 422 & 0.00 & 17.03 & & 13.30 & 216 & -5.08 & -6.17 & 1,086 & 21 & 22 & 0.2221 & 953 & 391 & 1,241 \\
\hline $\min$ & 400 & 0.00 & 16.54 & & 13.14 & 203 & -5.76 & -6.76 & 1,065 & 4 & 2 & 0.0533 & 256 & 176 & 330 \\
\hline average & 344 & 47.59 & 16.10 & 7.98 & 27.93 & 201 & -4.46 & -6.28 & 1,078 & 6 & 4 & 0.0944 & 307 & 196 & 364 \\
\hline std dev & 2 & 0.00 & 0.07 & & 0.04 & 1 & 0.21 & 0.18 & 4 & 2 & 2 & 0.0113 & 52 & 20 & 60 \\
\hline $\max$ & 349 & 0.00 & 16.29 & & 28.05 & 203 & -3.34 & -5.37 & 1,084 & 13 & 11 & 0.1347 & 502 & 262 & 584 \\
\hline $\min$ & 341 & 0.00 & 15.90 & & 27.84 & 200 & -5.13 & -6.87 & 1,070 & 3 & 0 & 0.0791 & 222 & 157 & 266 \\
\hline average & 326 & 42.33 & 9.67 & 8.01 & 34.77 & 217 & -4.02 & -5.99 & 1,079 & 6 & 4 & 0.0946 & 284 & 252 & 348 \\
\hline std dev & 3 & 0.00 & 0.03 & & 0.07 & 2 & 0.34 & 0.29 & 1 & 3 & 2 & 0.0146 & 59 & 30 & 72 \\
\hline $\max$ & 330 & 0.00 & 9.76 & & 34.93 & 219 & -3.25 & -5.34 & 1,081 & 17 & 19 & 0.1389 & 490 & 346 & 596 \\
\hline $\min$ & 320 & 0.00 & 9.58 & & 34.58 & 212 & -4.83 & -6.76 & 1,078 & 2 & 0 & 0.0687 & 180 & 191 & 224 \\
\hline
\end{tabular}


Table A-4. Steady State Data for the Bubbled Run with 100\% Acid Stoichiometry Feed with 1X Antifoam (SS_100\%_B_1X).

\begin{tabular}{|c|c|c|c|c|c|c|c|c|c|c|c|c|c|c|c|}
\hline & $\begin{array}{c}\text { VS } \\
\text { Temp } \\
\end{array}$ & $\begin{array}{l}\text { Feed } \\
\text { Rate }\end{array}$ & $\begin{array}{l}\text { FC } \\
\text { Air }\end{array}$ & $\begin{array}{c}\text { Cam } \\
\text { Air }\end{array}$ & $\begin{array}{l}\text { VS } \\
\text { Air }\end{array}$ & $\begin{array}{c}\text { FC } \\
\text { Exit T } \\
\end{array}$ & $\begin{array}{c}\text { CEF } \\
\mathbf{P}\end{array}$ & $\begin{array}{c}\text { FC } \\
\text { Exit } \mathbf{P}\end{array}$ & $\begin{array}{l}\text { Glass } \\
\text { Temp }\end{array}$ & $\begin{array}{c}\text { H2 } \\
\text { (MS) }\end{array}$ & $\begin{array}{c}\text { CO } \\
\text { (FTIR) }\end{array}$ & $\begin{array}{l}\mathrm{CO2} \\
(\mathrm{MS})\end{array}$ & $\begin{array}{c}\text { NO } \\
\text { (MS) }\end{array}$ & $\begin{array}{l}\text { NO2 } \\
\text { (MS) }\end{array}$ & $\begin{array}{c}\text { N2O } \\
\text { (FTIR) }\end{array}$ \\
\hline & $\left({ }^{\circ} \mathrm{C}\right)$ & $(\mathrm{g} / \mathrm{min})$ & (scfm) & (scfm) & (scfm) & $\left({ }^{\circ} \mathrm{C}\right)$ & ("wc) & ("wc) & $\left({ }^{\circ} \mathrm{C}\right)$ & (ppm) & (ppm) & (vol\%) & (ppm) & (ppm) & (ppm) \\
\hline average & 705 & 170.49 & 15.25 & 8.39 & 0.52 & 358 & -4.81 & -5.50 & 1,050 & 19 & 161 & 0.6592 & 1,947 & 1,091 & 220 \\
\hline std dev & 5 & 0.00 & 0.05 & & 0.02 & 5 & 0.17 & 0.14 & 4 & 8 & 53 & 0.1316 & 242 & 290 & 52 \\
\hline $\max$ & 714 & 0.00 & 15.37 & & 0.55 & 370 & -4.08 & -4.88 & 1,057 & 55 & 344 & 1.0679 & 2,298 & 1,956 & 369 \\
\hline $\min$ & 691 & 0.00 & 15.12 & & 0.49 & 347 & -5.17 & -5.79 & 1,043 & 5 & 67 & 0.4343 & 578 & 205 & 135 \\
\hline average & 592 & 146.21 & 15.32 & 8.35 & 0.51 & 285 & -4.66 & -5.25 & 1,042 & 37 & 109 & 0.5123 & 1,682 & 866 & 165 \\
\hline std dev & 5 & 0.00 & 0.05 & & 0.01 & 6 & 0.20 & 0.16 & 6 & 16 & 60 & 0.1272 & 259 & 228 & 53 \\
\hline $\max$ & 602 & 0.00 & 15.51 & & 0.52 & 300 & -3.83 & -4.65 & 1,049 & 113 & 480 & 1.0635 & 2,283 & 2,031 & 406 \\
\hline $\min$ & 576 & 0.00 & 15.19 & & 0.49 & 278 & -5.01 & -5.57 & 1,029 & 20 & 49 & 0.3765 & 1,098 & 612 & 103 \\
\hline average & 471 & 122.69 & 15.32 & 8.29 & 6.09 & 235 & -4.42 & -5.22 & 1,041 & 31 & 55 & 0.3991 & 1,303 & 673 & 115 \\
\hline std dev & 8 & 0.00 & 0.05 & & 0.02 & 4 & 0.20 & 0.18 & 5 & 18 & 32 & 0.1101 & 323 & 178 & 40 \\
\hline $\max$ & 485 & 0.00 & 15.48 & & 6.14 & 244 & -3.67 & -4.55 & 1,053 & 108 & 150 & 0.7743 & 2,232 & 1,311 & 246 \\
\hline $\min$ & 456 & 0.00 & 15.13 & & 6.03 & 225 & -4.88 & -5.62 & 1,031 & 8 & 12 & 0.2624 & 857 & 443 & 72 \\
\hline average & 373 & 101.80 & 15.50 & 7.97 & 25.94 & 219 & -5.06 & -6.96 & 1,025 & 18 & 20 & 0.2178 & 689 & 340 & 56 \\
\hline std dev & 5 & 0.00 & 0.08 & & 0.04 & 2 & 0.26 & 0.23 & 5 & 6 & 9 & 0.0259 & 104 & 38 & 10 \\
\hline $\max$ & 384 & 0.00 & 15.77 & & 26.06 & 226 & -4.03 & -6.05 & 1,035 & 65 & 69 & 0.3338 & 1,155 & 511 & 99 \\
\hline $\min$ & 363 & 0.00 & 15.32 & & 25.82 & 215 & -5.84 & -7.73 & 1,016 & 8 & 6 & 0.1729 & 471 & 263 & 39 \\
\hline average & 323 & 88.29 & 6.12 & 7.86 & 45.90 & 224 & -1.13 & -3.61 & 1,031 & 13 & 18 & 0.1297 & 545 & 268 & 674 \\
\hline std dev & 10 & 0.00 & 0.04 & & 0.06 & 7 & 0.30 & 0.27 & 2 & 8 & 10 & 0.0258 & 152 & 55 & 188 \\
\hline $\max$ & 341 & 0.00 & 6.20 & & 46.04 & 238 & 1.16 & -1.68 & 1,035 & 69 & 86 & 0.2697 & 1,319 & 546 & 1,625 \\
\hline $\min$ & 302 & 0.00 & 6.02 & & 45.74 & 207 & -1.96 & -4.39 & 1,025 & 3 & 4 & 0.0719 & 318 & 185 & 399 \\
\hline
\end{tabular}


Table A-5. Steady State Data for the Non-Bubbled Run with 100\% Acid Stoichiometry Feed with 2X Antifoam (SS_100\%_NB_2X).

\begin{tabular}{|c|c|c|c|c|c|c|c|c|c|c|c|c|c|c|c|}
\hline & $\begin{array}{c}\text { VS } \\
\text { Temp } \\
\end{array}$ & $\begin{array}{l}\text { Feed } \\
\text { Rate } \\
\end{array}$ & $\begin{array}{l}\text { FC } \\
\text { Air } \\
\end{array}$ & $\begin{array}{c}\text { Cam } \\
\text { Air } \\
\end{array}$ & $\begin{array}{l}\text { VS } \\
\text { Air } \\
\end{array}$ & $\begin{array}{c}\text { FC } \\
\text { Exit T } \\
\end{array}$ & $\begin{array}{c}\text { CEF } \\
\mathbf{P} \\
\end{array}$ & $\begin{array}{c}\text { FC } \\
\text { Exit } \mathbf{P} \\
\end{array}$ & $\begin{array}{l}\text { Glass } \\
\text { Temp } \\
\end{array}$ & $\begin{array}{c}\text { H2 } \\
\text { (MS) }\end{array}$ & $\begin{array}{c}\text { CO } \\
\text { (FTIR) }\end{array}$ & $\begin{array}{l}\text { CO2 } \\
(\mathrm{MS}) \\
\end{array}$ & $\begin{array}{c}\text { NO } \\
\text { (MS) } \\
\end{array}$ & $\begin{array}{l}\text { NO2 } \\
\text { (MS) } \\
\end{array}$ & $\begin{array}{c}\text { N2O } \\
\text { (FTIR) }\end{array}$ \\
\hline & $\left({ }^{\circ} \mathrm{C}\right)$ & $(\mathrm{g} / \mathrm{min})$ & $(\mathrm{scfm})$ & (scfm) & $(\mathrm{scfm})$ & $\left({ }^{\circ} \mathrm{C}\right)$ & ("wc) & ("wc) & $\left({ }^{\circ} \mathrm{C}\right)$ & (ppm) & (ppm) & (vol\%) & (ppm) & (ppm) & $(\mathrm{ppm})$ \\
\hline average & 722 & 102.72 & 16.14 & 8.60 & 0.19 & 334 & -2.92 & -3.67 & 1,097 & 6 & 154 & 0.5765 & 1,522 & 794 & 107 \\
\hline std dev & 2 & 0.00 & 0.05 & & 0.01 & 3 & 0.07 & 0.06 & 2 & 9 & 53 & 0.1126 & 246 & 155 & 26 \\
\hline $\max$ & 726 & 0.00 & 16.26 & & 0.20 & 340 & -2.78 & -3.56 & 1,102 & 27 & 348 & 0.8947 & 2,395 & 1,354 & 210 \\
\hline $\min$ & 719 & 0.00 & 16.02 & & 0.17 & 329 & -3.09 & -3.84 & 1,093 & 0 & 69 & 0.4235 & 1,090 & 547 & 67 \\
\hline average & 604 & 46.65 & 15.97 & 8.61 & 0.41 & 292 & -5.38 & -6.14 & 1,071 & 60 & 213 & 0.4841 & 1,300 & 728 & 103 \\
\hline std dev & 7 & 0.00 & 0.05 & & 0.01 & 4 & 0.13 & 0.12 & 3 & 12 & 39 & 0.0346 & 115 & 81 & 13 \\
\hline $\max$ & 616 & 0.00 & 16.09 & & 0.45 & 302 & -4.86 & -5.64 & 1,074 & 101 & 373 & 0.6223 & 1,717 & 1,017 & 149 \\
\hline $\min$ & 593 & 0.00 & 15.83 & & 0.39 & 285 & -5.63 & -6.42 & 1,062 & 38 & 138 & 0.4104 & 1,028 & 566 & 75 \\
\hline average & 519 & 57.41 & 15.99 & 8.56 & 0.42 & 222 & -5.12 & -5.77 & 1,066 & 10 & 89 & 0.2563 & 787 & 451 & 59 \\
\hline std dev & 4 & 0.00 & 0.05 & & 0.01 & 2 & 0.08 & 0.07 & 6 & 4 & 29 & 0.0498 & 163 & 90 & 16 \\
\hline $\max$ & 524 & 0.00 & 16.12 & & 0.45 & 226 & -4.89 & -5.56 & 1,080 & 29 & 241 & 0.5195 & 1,614 & 935 & 166 \\
\hline $\min$ & 514 & 0.00 & 15.85 & & 0.39 & 217 & -5.34 & -5.97 & 1,056 & 5 & 51 & 0.1809 & 527 & 320 & 35 \\
\hline average & 397 & 49.35 & 15.85 & 8.48 & 19.00 & 211 & -4.63 & -6.29 & 1,052 & 9 & 51 & 0.1545 & 392 & 223 & 28 \\
\hline std dev & 10 & 0.00 & 0.05 & & 0.04 & 3 & 0.08 & 0.07 & 5 & 3 & 14 & 0.0294 & 96 & 42 & 10 \\
\hline $\max$ & 412 & 0.00 & 16.00 & & 19.11 & 217 & -4.42 & -6.10 & 1,058 & 22 & 109 & 0.2492 & 723 & 356 & 66 \\
\hline $\min$ & 383 & 0.00 & 15.70 & & 18.91 & 207 & -4.90 & -6.51 & 1,039 & 3 & 24 & 0.1032 & 209 & 142 & 14 \\
\hline average & 323 & 39.14 & 10.01 & 8.47 & 27.97 & 211 & -4.04 & -5.97 & 1,067 & 9 & 22 & 0.1178 & 287 & 163 & 20 \\
\hline std dev & 6 & 0.00 & 0.04 & & 0.05 & 2 & 0.10 & 0.09 & 3 & 2 & 7 & 0.0148 & 60 & 24 & 5 \\
\hline $\max$ & 330 & 0.00 & 10.09 & & 28.16 & 214 & -3.70 & -5.66 & 1,072 & 17 & 49 & 0.1895 & 575 & 272 & 41 \\
\hline $\min$ & 313 & 0.00 & 9.88 & & 27.85 & 208 & -4.31 & -6.17 & 1,061 & 5 & 8 & 0.0901 & 185 & 121 & 12 \\
\hline average & 293 & 36.81 & 5.69 & 8.46 & 34.39 & 227 & -2.80 & -4.88 & 1,066 & 10 & 27 & 0.1104 & 243 & 146 & 21 \\
\hline std dev & 5 & 0.00 & 0.04 & & 0.09 & 1 & 0.29 & 0.25 & 2 & 2 & 7 & 0.0120 & 45 & 19 & 4 \\
\hline $\max$ & 300 & 0.00 & 5.77 & & 34.60 & 229 & -2.22 & -4.40 & 1,069 & 17 & 61 & 0.1656 & 461 & 229 & 41 \\
\hline $\min$ & 283 & 0.00 & 5.61 & & 34.25 & 223 & -3.36 & -5.40 & 1,064 & 6 & 16 & 0.0886 & 177 & 118 & 14 \\
\hline
\end{tabular}


SRNL-STI-2014-00355

Revision 0

Appendix B.

Design Check Lists

B-1 
Report Title: DWPF Melter Off-Gas Flammability Reviewer: F. G. Smith, III

Model for the Nitric-Glycolic Acid Flowsheet

Document No. SRNL-STI-2014-00355

Activity Code: 006ZL4A244

Current Date: 9/3/2014

Author(s): A. S. Choi

Date Needed: 9/3/2014

Location of report and supplemental information: A report and spreadsheets containing the data and calculations sent by Email

\begin{tabular}{|c|c|c|c|}
\hline$\checkmark$ & $\begin{array}{l}\text { Analytical/Experimental } \\
\text { Approach }\end{array}$ & Instruction: & $\begin{array}{l}\text { Check for the integrity and consistency of the } \\
\text { overall approach taken. }\end{array}$ \\
\hline$\checkmark$ & Mathematical Check & Instruction: & $\begin{array}{l}\text { Check for the accuracy of calculations made in } \\
\text { the spreadsheets in terms of charge, mass and } \\
\text { heat balances. }\end{array}$ \\
\hline$\checkmark$ & Inputs & Instruction: & $\begin{array}{l}\text { Check if pertinent steady state data was selected } \\
\text { from the database and imported correctly into the } \\
\text { spreadsheet. }\end{array}$ \\
\hline$V$ & Assumptions & Instruction: & $\begin{array}{l}\text { Check if the assumptions made in the revised } \\
\text { model are reasonable and based on accepted } \\
\text { practice in the literature. }\end{array}$ \\
\hline$V$ & Output & Instruction: & $\begin{array}{l}\text { Check if the calculation results are consistent with } \\
\text { the expected outcome and interpreted correctly. }\end{array}$ \\
\hline$V$ & Transcription & Instruction: & $\begin{array}{l}\text { Check if the output of calculations are property } \\
\text { tabulated and plotted. }\end{array}$ \\
\hline
\end{tabular}

Design Check Completed By:

Date: $9 / 3 / 2014$

Comment Resolution Accepted By:

Date: $9 / 3 / 2014$

Date: 
Report Title: DWPF Melter Off-Gas Flammability

Model for the Nitric-Glycolic Acid Flowsheet

Document No. SRNL-STI-2014-00355

Author(s): A. S. Choi
Reviewer: W. E. Daniel

Activity Code: 006ZL4A244

Current Date: 9/3/2014

Date Needed: 9/3/2014

Location of report and supplemental information: A report and spreadsheets containing

data and calculations sent by Email

\begin{tabular}{|c|c|c|}
\hline $\begin{array}{l}\checkmark \text { Analytical/Experimental } \\
\text { Approach }\end{array}$ & Instruction: & $\begin{array}{l}\text { Check for the integrity and consistency of the } \\
\text { overall approach taken. }\end{array}$ \\
\hline$\sqrt{ }$ Mathematical Check & Instruction: & $\begin{array}{l}\text { Check for the accuracy of calculations made in } \\
\text { the spreadsheets in terms of charge, mass and } \\
\text { heat balances. }\end{array}$ \\
\hline$\sqrt{ }$ Inputs & Instruction: & $\begin{array}{l}\text { Check if pertinent steady state data was selected } \\
\text { from the database and imported correctly into the } \\
\text { spreadsheet. }\end{array}$ \\
\hline$\sqrt{ }$ Assumptions & Instruction: & $\begin{array}{l}\text { Check if the assumptions made in the revised } \\
\text { model are reasonable and based on accepted } \\
\text { practice in the literature. }\end{array}$ \\
\hline$\sqrt{ }$ Output & Instruction: & $\begin{array}{l}\text { Check if the calculation results are consistent with } \\
\text { the expected outcome and interpreted correctly. }\end{array}$ \\
\hline$\sqrt{ }$ Transcription & Instruction: & $\begin{array}{l}\text { Check if the output of calculations are property } \\
\text { tabulated and plotted. }\end{array}$ \\
\hline
\end{tabular}

Design Check Completed By:

Date: 9

Comment Resolution Accepted By:

Date:

Date: $9 / 3 / 14$ 


\section{Distribution:}

S. L. Marra, 773-A

T. B. Brown, 773-A

S. D. Fink, 773-A

C. C. Herman, 773-A

E. N. Hoffman, 999-W

F. B. Johnson, 999-W

D. H. McGuire, 999-W

D. K. Peeler, 999-W

F. M. Pennebaker, 773-42A

W. R. Wilmarth, 773-A

Records Administration (EDWS)

R. E. Edwards, 766-H

E. J. Freed, 704-S

J. M. Bricker, 704-30S

T. L. Fellinger, 766-H

J. M. Gillam, 766-H

B. A. Hamm, 766-H

E. W. Holtzscheiter, 766-H

J. F. Iaukea, 704-27S

D. W. McImoyle, 766-H

Q. L. Nguyen, 704-30S

J. W. Ray, 704-27S

P. J. Ryan, 704-30S

H. B. Shah, 766-H

D. C. Sherburne, 704-S

M. E. Smith, 704-30S

J. R. Vitali, 766-H

P. R. Jackson, DOE-SR, 703-46A 